\title{
Recent French Export Performance: \\ Is There a Competitiveness Problem?
}

\author{
Alain Kabundi and \\ Francisco Nadal De Simone
}



IMF Working Paper

European Department

\title{
Recent French Export Performance: Is There a Competitiveness Problem? Prepared by Alain Kabundi ${ }^{1}$ and Francisco Nadal De Simone ${ }^{2}$
}

Authorized for distribution by Jeffrey Franks

January 2009

\begin{abstract}
This Working Paper should not be reported as representing the views of the IMF. The views expressed in this Working Paper are those of the authors and do not necessarily represent those of the IMF or IMF policy. Working Papers describe research in progress by the author(s) and are published to elicit comments and to further debate.
\end{abstract}

Recently, the export performance of France relative to its own past and relative to a major trading partner, Germany, deteriorated. That deterioration seems related to the geographical destination and product composition of trend exports. Faced with an increase in unit labor costs or in its terms of trade, France adjusts relatively less via price and wage changes, and more via employment changes. Given that SMIC convergence resulted in a significant increase in unit labor costs, foreign sector difficulties might be structural. Trade flows relevance and euro area policy constraints highlight the importance of structural reforms that increase markets flexibility.

JEL Classification Numbers: C33, F42

Keywords: Competitiveness, Dynamic Factor Models, Productivity

Author's E-Mail Address: akabundi@uj.ac.za; francisco.nadaldesimone@bcl.lu

\footnotetext{
${ }^{1}$ Department of Economics, University of Johannesburg.

${ }^{2}$ This paper was written while the author was a staff member of the European Department, IMF. Now, the author is at the Central Bank of Luxembourg.
} 


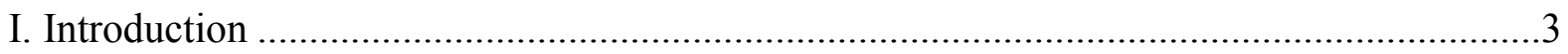

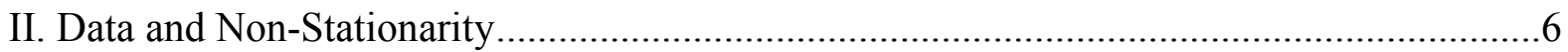

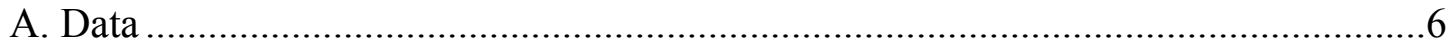

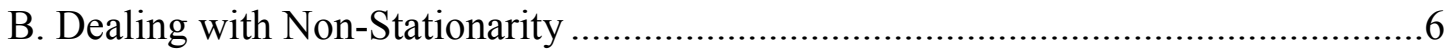

III. Descriptive Part: Facts Without the Noise _.......................................................................

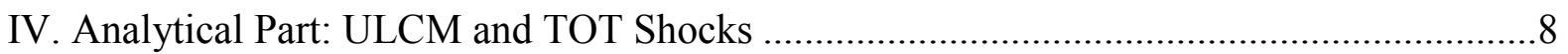

A. The Model and Economic Conditions for Shocks Identification...............................8

B. Estimation................................................................................................

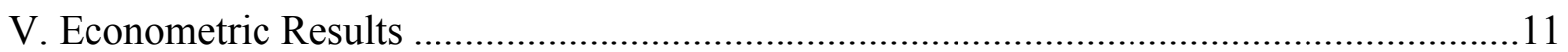

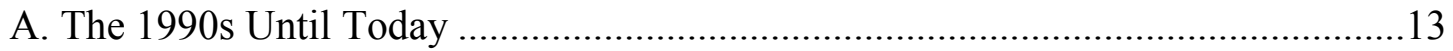

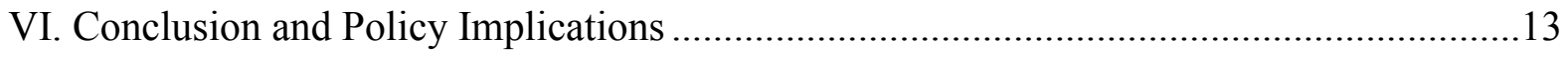

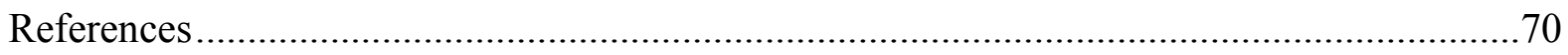

Tables

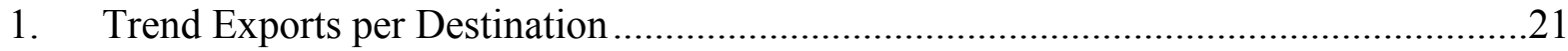

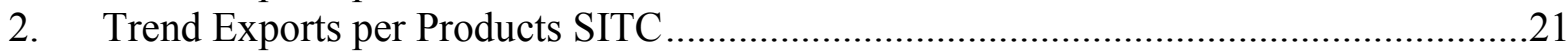

3. Forecast Error Variance of the Common Components of French Variables Explained by the Supply and Demand Shocks to Unit Labor Costs in Manufacturing, 1980-2006

4. Forecast Error Variance of the Common Components of German Variables Explained by the Supply and Demand Shocks to Unit Labor Costs in Manufacturing, 1980-2006

5. Forecast Error Variance of the Common Components of French Variables

Explained by the Supply and Demand Shocks to Terms of Trade, 1980-2006 ..........24

6. Forecast Error Variance of the Common Components of German Variables

Explained by the Supply and Demand Shocks to Terms of Trade, 1980-2006 ..........25

7. Forecast Error Variance of the Common Components of French Variables

Explained by the Supply and Demand Shocks to ULCM, 1993-2006........................26

8. Forecast Error Variance of the Common Components of German Variables

Explained by the Supply and Demand Shocks to ULCM, 1993-2006.

Figures

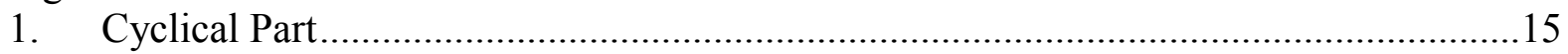

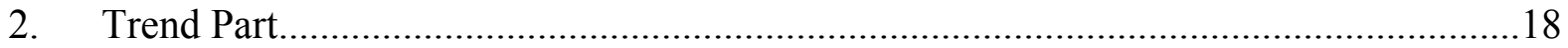

Appendices

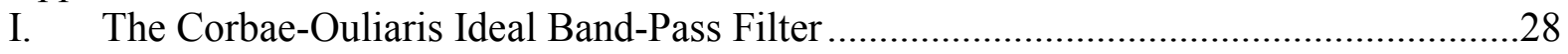

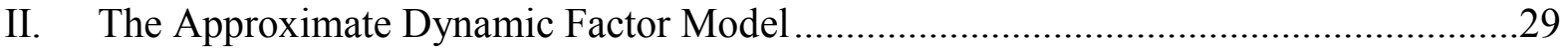

Annexes

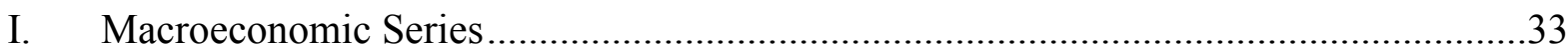

II. France and Germany: Shocks to ULCM and TOT ......................................................46 


\section{INTRODUCTION}

Evidence shows that a significant part of French activity fluctuations has a foreign source (e.g., Kose, Otrok, and Whiteman, 2003; and Kabundi and Nadal De Simone, 2007). In particular, since 2000, French foreign sector performance has experienced a substantial deterioration vis-à-vis its own past and relative to Germany. Some observers have suggested that the country has not benefited fully from the opportunities offered by the rapid economic performance of emerging Asian economies and the eastward expansion of the European Union (EU). Therefore, the question arises as to whether France is suffering from a competitiveness problem. This question has had, so far, an elusive answer. Traditional variables that explain international trade, such as the exchange rate, relative unit labor costs, and demand pressure seem insufficient to illuminate the recent decline in France's export performance. Residuals from econometrically-estimated equations indicate a substantial drag on exports since 2001, not attributable to the standard global demand and price/cost factors. ${ }^{3}$

In addition, equilibrium exchange rate analysis indicates that France's real effective exchange rate is largely in line with fundamentals. National account data show, however, that changes in export margins have cushioned the effects of the euro fluctuations. Cost competitiveness of French producers worsened in 2005 and early 2006, though it remains in line with its long-term average. Despite that producers lowered export prices in euros to maintain price competitiveness, the external position deteriorated during the period.

Hence, the relative underperformance of exports in past years may point to structural factors that leave French firms behind the global expansion. A more flexible economy should be able to reorient the destination of its exports and product mix toward fast-growing economies and sectors. Indeed, a sectoral study of total factor productivity (TFP) growth in manufacturing found that, while France does not lag significantly behind the United States in terms of level, TFP growth is hampered by the high ratio of minimum to median wages. ${ }^{4}$ Staff analysis also suggests that as France has become more sensitive to the global economy over time, it has tended to adjust more through changes in employment and productivity than through wage flexibility, strengthening the case for more structural reforms. ${ }^{5}$

\footnotetext{
* We thank participants at seminars at the MINEFI, France, ECB, and the European Department of the IMF for valuable comments on previous versions of this paper. Susan Becker made an efficient and dedicated management of the large databases used in this study. Any remaining errors or omissions are authors' responsibility.

${ }^{3}$ See IMF, 2005.

${ }^{4}$ See Khan, 2006.

${ }^{5}$ See Kabundi and Nadal De Simone, 2007.
} 
This paper performs a descriptive analysis of French export data by destination and by SITC product classification distinguishing between the cyclical and the trend components of the series. Next, it analyzes the behavior of prices and quantities following a domestic and a foreign shock to the French economy; the paper contrasts and compares the reaction of French and German variables to shocks to unit labor costs and to terms of trade.

Globalization has greatly influenced economies over the past three decades. Countries' boundaries have dropped through intensive trade of goods and services, and financial integration. Economies have benefited from trade and foreign direct investment (FDI). Conversely, globalization can make countries more vulnerable to external shocks. Crises can be severe and contagion can spread rapidly to other parts of the globe, as recently exemplified by the subprime crisis that started in the United States.

There is a consensus in the literature that globalization has largely positive effects. Globalization fosters comovement of macroeconomic variables across countries through trade integration and financial market integration (IMF, 2001; and Imbs, 2004). An increase in exports in one country boosts economic activity of the recipient country (Canova and Dellas, 1993; and IMF, 2001). Such spillover effects lead to high correlation of business cycles.

The integration of financial markets has also contributed to the synchronization of business cycles through the opening of countries' capital accounts. Financial prices have become more synchronized through arbitrage (e.g., the global slowdown of 2000-01 was caused by the crash of the technology stock market in the United States). Financial comovements tend to be substantially larger than comovements in the real economy, and financial comovement has increased for financial markets over time (Brooks, Forbes, and Mody, 2003).

On the empirical front, most findings show increasing synchronization of economic variables across countries. Kose, Otrok, and Whiteman (2005), using the Bayesian dynamic factor model, extract common components in output, consumption, and investment and find that the degree of synchronization of business cycles of major macroeconomic aggregates across G-7 countries has increased over time. On the nature of shocks that drive the comovement, they find that oil-price shocks are behind synchronization of cycles during the "common shocks" period. Nadal-De Simone (2002), using a concordance index proposed by Harding and Pagan (2002) and the dynamic factor model of Stock and Watson (1991), finds evidence of a global component as well as a regional component that explains the comovement between European economies themselves and with the United States. In the same vein, Monfort and others (2004); Kose, Otrok, and Whiteman (2003); Malek Mansour (2003); Yang (2003); Lumsdaine and Prasad (2003); Bordo and Helbling (2004); and Canova, Ciccarelli, and Ortega (2007) support the view that fluctuations of most macroeconomic variables across developed countries are mainly driven by a global factor. 
In contrast, Kose and Yi (2006); Kose, Prasad, and Terrones (2003); Stock and Watson (2003); and Heitz, Hild, and Monfort (2004) find that G-7 business cycles have become less synchronized. A possible reason is that trade flows could lead to increased specialization resulting in changes in the nature of business cycles. Trade ties are closely related to a rise in inter-industry specialization across nations, and then industry-specific shocks are the main driving forces of business cycles. Synchronization may be thus reduced. Similarly, international financial linkages could also stimulate production through the reallocation of capital in a manner consistent with countries' comparative advantage (Imbs, 2004), which in turn reduces business cycle synchronization.

Other studies have emphasized the sources of shocks, their spillovers, and channels of their transmission. Recent examples include the study of the monetary transmission mechanism in the euro area using structural VAR analysis by Peersman (2005); Canova, Ciccarelli, and Ortega (2007); and Ciccarelli and Rebucci (2006). Similarly, Canova and Ciccarelli (2006), using a VAR with time-varying parameters, find a positive and significant effect of U.S. GDP growth shock on France and Italy, but a negligible effect on German GDP growth. Canova (2005) uses a structural VAR approach and finds that U.S. monetary shocks have a strong influence, while real supply and demand shocks have a minor effect. Given the limitations of the VAR methodology - the most conspicuous being that it cannot accommodate a large panel of series without the risk of running short of degrees of freedom - Stock and Watson (1998 and 2002) use the approximate structural dynamic factor model on a large panel of developed countries' variables. Like Kabundi and Nadal De Simone (2007) and Eickmeier (2007), find a positive and significant effect of U.S. demand shocks on French and German output, while EU supply shocks tend to have important effects on French and German output.

The high degree of integration, and with it the exposure of countries to shocks, stresses the importance of good and factor markets flexibility. Economies' flexibility to absorb domesticand foreign origin shocks takes paramount importance, even more so when countries' policy menu is restricted in some sense such as by participation in a currency area. Not surprisingly, competitiveness issues have been taken to the front line of the economic and political debate.

This study contains several findings. (1) Divergences in recent trade performance between France and Germany are not related to the cyclical part of trade but to its trend. (2) For most categories of products, France's export cyclical component is less volatile than Germany's. (3) In the 2000s, France's trend export growth rate while higher than in the 1990s, was less than 60 percent Germany's. (4) Both France and Germany faced a negative common factor in the 2000 s, most likely due to the euro appreciation. (5) However, idiosyncratic factors were negative on average for France and positive for Germany. (6) The French economy seems less flexible to adjust to a negative shock to unit labor costs in manufacturing or to its terms of trade: the adjustment tends to be done relatively more via quantities than via prices suggesting the need to make labor and product markets as flexible as possible. 
Section II discusses the data and elaborates on the methodology to deal with non-stationarity in the data. Section III describes the cyclical and trend components of French exports by destination and by product. Section IV analyzes the response of the French economy to a shock to unit labor costs in manufacturing and to the terms of trade. Section V discusses the policy implications of the study.

\section{DATA AND NON-STATIONARITY}

\section{A. Data}

This study uses two large data panels. The first one comprises 396 quarterly macroeconomic series and 106 Direction of Trade (DOT) series of trade by country (for a total of series $N=$ 502). DOT series include imports and exports to the euro area, the EU, Ascension countries, Canada, the United States, the United Kingdom, Japan, China, Asia, Latin America, and the rest of the world. The second data panel contains 396 quarterly macroeconomic series and 110 series of trade by SITC Revision 3 category of products (for a total of series $N=506$ ). The sample period is 1981:Q1-2006:Q4, or 104 observations for the two data panels (i.e., $T$ =104). The countries included in the sample are France, Germany, Japan, the Netherlands, the United Kingdom, and the United States. In addition to national variables, a set of global variables is included, containing such items as crude oil prices, a commodity industrial inputs price index, world demand, and world reserves. The variables cover the real sector of the economy including consumption, investment, international trade in goods and services, portfolio flows and FDI flows, prices, financial variables, and confidence indicators. All variables have had their seasonal component removed. The complete list of variables used in this study is in Annex I.

\section{B. Dealing with Non-Stationarity}

For estimation purposes, series have to be covariance stationary. Instead of applying unit root tests to determine the degree of integration of the series and then difference or detrend them depending on whether they are I(1) or I(0) with a deterministic trend, respectively, the Corbae-Ouliaris Ideal Band-Pass Filter was used. See Appendix I for a technical description of the filter. The reason for this approach is twofold. First, as is well known, currently available unit root tests have low power and often the decision on the degree of integration of the series has to be based on subjective judgment. Second, it is also known that first differencing removes a significant part of the variance of economic time series. Third, the ideal band-pass filter of Corbae and Ouliaris is consistent, is not subject to end-point problems and has no finite sampling error. As an illustration of these points, note the large share of variance that first differencing of French real GDP produces at the business cycle frequency band (between 6 and 32 quarters, according to the NBER definition of business cycles) (text figure). 
France: Spectra of Real GDP Filtered

( $Y$ axis: spectrum; $\mathrm{X}$ axis: periodicities in quarters)

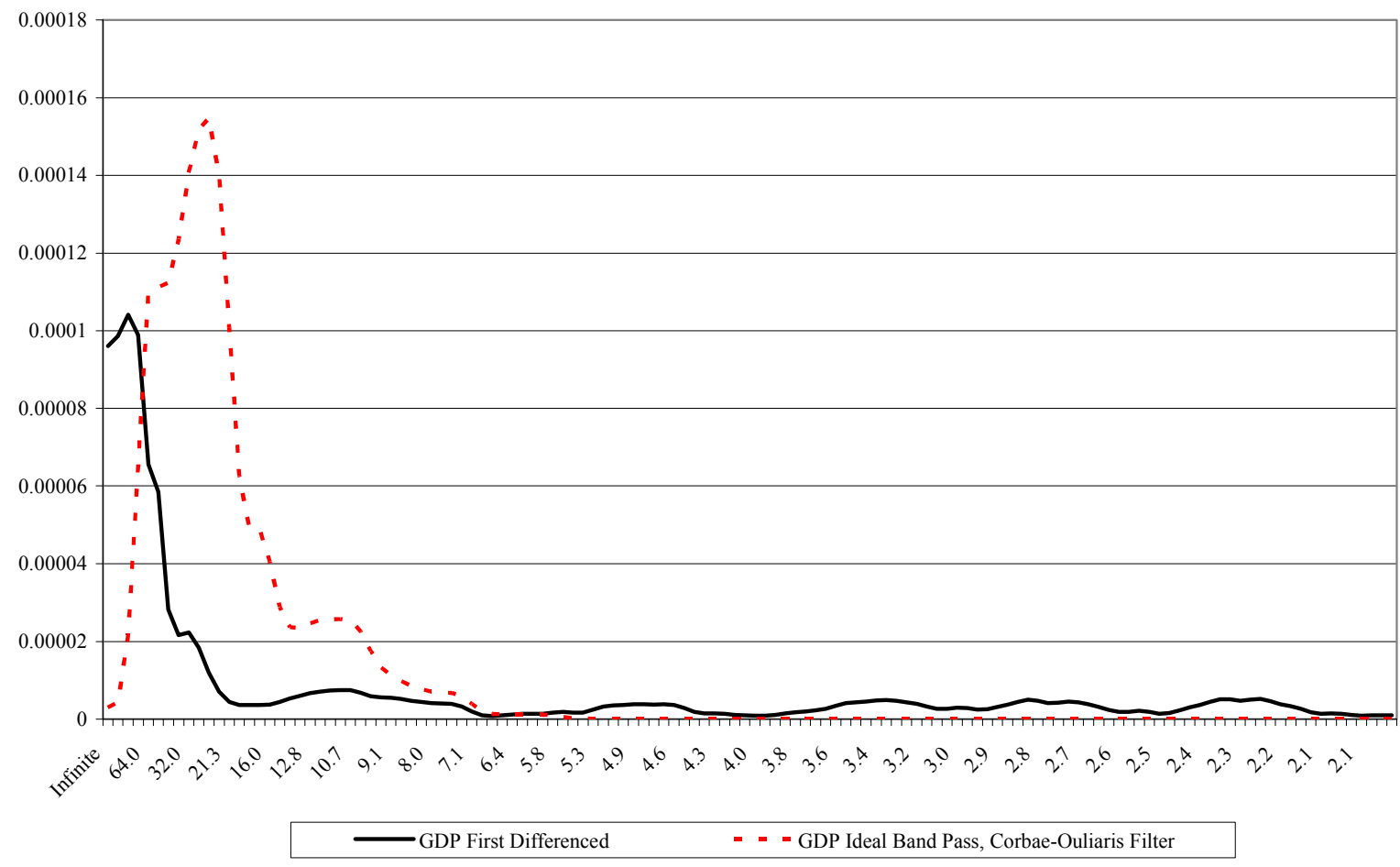

\section{Descriptive Part: Facts Without the Noise}

Several interesting features of recent French export performance are clear from the data once the noise of short-term fluctuations is removed. First, the cyclical components of exports by country and products of France and Germany follow the same pattern, mimicking quite closely their business cycles (Figure 1). Export cycles of both countries portray a picture of negative growth in the early 1980s and 1990s, and at the end of the 1990s. The U.S. driven early-1980s recession, the European 1993 recession and the end of the stock market "bubble" at the end of the 1990s are clearly correlated to exports behavior (IMF, 2005). But, in general, France's export cyclical component is less volatile than Germany's, which may be associated with the product composition of both countries exports; German exports products have a higher short-term elasticity. Hence, divergences in recent trade performance between France and Germany do not seem to be related to the cyclical part of trade flows. What about the trend in trade flows?

Figure 2 shows annual trend growth of exports. Looking at exports by destination, it seems that Germany has benefited more from the excellent economic performance of China than France. Starting in 2002-03, French export performance is also weak relative to Germany in terms of exports to the EU, the euro area, the United States, and the United Kingdom. France's export performance is also weaker relative to its own past. In the 1980s, French 
trend export growth dominated Germany's only with respect to China; the reverse was true in the 1990s (Table 1). In the 2000s, France's trend export growth rate, while higher than in the 1990s, was less than 60 percent of Germany's.

The deterioration of French export performance vis-à-vis its own past and relative to Germany can be related to products exported. In the 1980s, French trend export growth dominated Germany's in primary products, chemicals, and miscellaneous manufactured products; the situation was almost the opposite in the 1990s. In the 2000s, of the traditional French exports, France's trend export growth rate was higher than Germany's only in chemicals and "other" goods.

The analysis of trend growth rates suggests that there has been since 2002-03 a clear underperformance of French exports relative to the past and also relative to Germany. That France seems less competitive in recent years does not seem to be related to the euro; France's underperformance is quite broad from a product viewpoint. The change in export performance is relatively recent, but has been protracted enough so as to raise the question of the competitiveness of the French economy. More analysis and time is needed, however, to conclude that there is a structural issue.

\section{Analytical Part: ULCM And TOT Shocks}

\section{A. The Model and Economic Conditions for Shocks Identification}

To gain further insight into the possible causes of the deteriorating performance of the French foreign sector, this study uses a large dimensional approximate dynamic factor model following the static factor model of Stock and Watson (1998 and 2002). ${ }^{6}$ The methodology for estimating of the model comprises two main steps. First, estimating the common components of a large panel of data, and second, identifying a reduced number of structural shocks that explain the common components of the variables of interest. ${ }^{7}$ Once a decision is taken on the process followed by the common components, structural shocks have to be identified. The identification of structural shocks is achieved by focusing on the reduced form VAR residuals. Following Eickmeier (2007), the identification scheme has three steps. First, maximize the variance of the forecast error of the chosen variable and calculate impulse-response functions. Second, the identified shocks are assumed to be linearly correlated to a vector of fundamentals. Finally, orthogonal shocks are identified by rotation using a sign-identification strategy imposing inequality restrictions on the impulse-response

\footnotetext{
${ }^{6}$ This model is closely related to the traditional factor models of Sargent and Sims (1977) and Geweke (1977), except that it admits the possibility of serial correlation and weakly cross-sectional correlation of idiosyncratic components, as in Chamberlain (1983) and Chamberlain and Rothschild (1983). Similar models have recently been used by Giannone, Reichlin, and Sala (2002), Forni and others (2005), and Eickmeier (2007).

${ }^{7}$ See Appendix II for a technical description. See also Kabundi and Nadal De Simone (2007).
} 
functions of variables based on a typical aggregate demand/aggregate supply framework. ${ }^{8}$ Only those rotations among all possible rotations that have a structural meaning are chosen.

The choice of the variables of interest was motivated by two observations. First, France economic activity is largely influenced by developments in the rest of the world. Thus, it seemed natural to identify a terms of trade (TOT) shock to contrast and compare the behavior of France relative to Germany. Second, in the period of concern, only using unit labor cost measures of the REER, can be seen that French competitiveness deteriorated against Germany in the euro area, although it improved against some other countries. Wages have increased faster in France particularly at the bottom of the scale; these increases have been only partially compensated by higher productivity growth (text figure). Therefore, the second shock that was identified was a shock to unit labor costs in manufacturing (ULCM). The choice seemed also relevant in view of the results of the previous section.

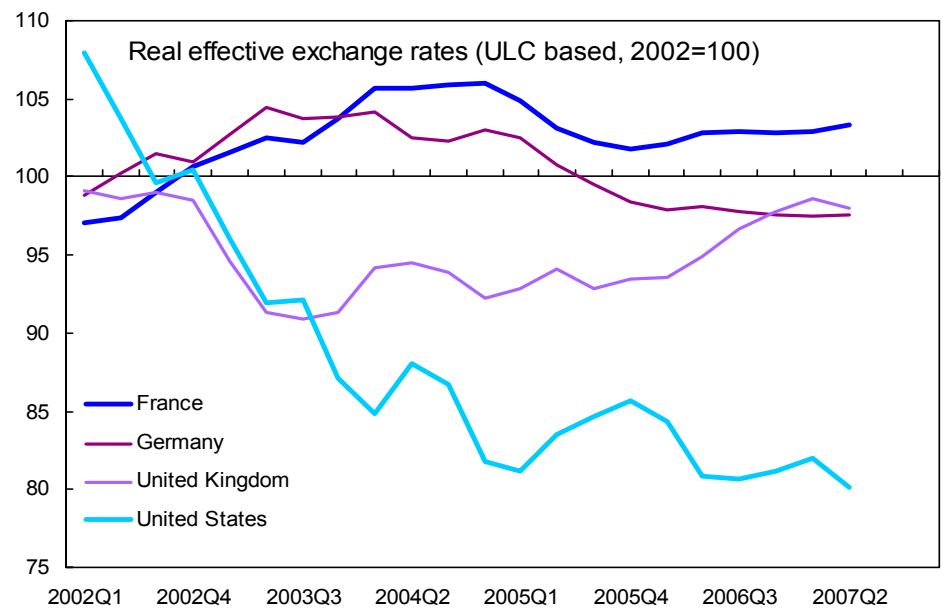

The text table displays the sign restrictions for the identification of shocks that are imposed contemporaneously and during the first year after the shock.

As in major standard macroeconomic models, an increase in ULCM can be interpreted as the result of a fall in labor productivity or an increase in labor compensation. The former is going to be interpreted as a supply shock and the later as a demand shock. This is consistent with the empirical observation that real wages are procyclical. Similarly, a rise in the TOT can result from a deterioration of the country's competitiveness related to structural factors or alternatively from strong world demand for the country's products. If the shock is persistent, it will Identification Inequalities

\begin{tabular}{lcc}
\hline & \multicolumn{2}{c}{ Increase in ULCM } \\
\cline { 2 - 3 } & Supply shock & Demand shock \\
\hline ULCM & $\leq 0$ & $\geq 0$ \\
Output & $\leq 0$ & $\geq 0$ \\
Real wages & \multicolumn{2}{c}{ Increase in Terms of Trade } \\
\hline & Supply shock & Demand shock \\
\hline \multirow{2}{*}{ Terms of trade } & $\geq 0$ & $\geq 0$ \\
Consumption & $\geq 0$ & $\leq 0$ \\
Current account & $\leq 0$ & $\geq 0$ \\
\hline
\end{tabular}
result in an increase in consumption (and

\footnotetext{
${ }^{8}$ See Peersman (2005) for more technical details.
} 
investment) and the current account will move into deficit. In contrast, if the TOT increase is due to strong world demand for the small country's products, given the transient nature of the shock, consumers will largely save the windfall and the current account will move into surplus. Savings will increase.

\section{B. Estimation}

The first step of the estimation is the determination of the number of factors. The estimation was done assuming that the series follow an approximate dynamic factor model. ${ }^{9}$ Using Bai and Ng's (2002) selection criteria, four factors were retained. Not much can be concluded from the inspection of the factors and their loadings, however, because factors are identified only up to a rotation. Moreover, factors can be a linear combination not only of their contemporaneous values, but also of their lags.

Next, the identification of the structural shocks followed the approach of the structural VAR literature. No identification technology is completely foolproof, however. While the identification technology followed in this paper is flexible enough not to require special restrictions to disentangle common shocks from the contemporaneous transmission of regional or country-specific shocks, it does require additional work, for example, to confirm the nature and source of shocks. In order to properly distinguish a global (common) shock from the transmission within the same period of a country- or regional-specific shock, following Eickmeier (2007), this paper does not restrict the impact effect of the shock. Moreover, after identifying two shocks and giving them an economic interpretation, this study performs the same analysis on a data set containing only French variables. It finds that the impulse-responses of the French-only data set and the broader data set are similar, bringing thus further comfort as to the identification of the source of the shocks.

As it is well know in the literature, only two structural shocks could be identified for each variable of interest. The identification procedure proposed by Uhlig (2003) was applied to the common components of France and Germany's ULCM and TOT so as to find a reduced number of structural shocks that maximizes the explanation of its forecast error variance over 20 periods.

Sign restrictions on impulse response functions were used to provide economic meaning to the structural shocks. Following Peersman (2005), the angle rotations were applied to the first two principal component shocks taking as pairs a supply shock and a demand shock. The bootstrap was made up of 500 draws. ${ }^{10}$ The impulse-response functions are calculated for the

\footnotetext{
${ }^{9}$ We are deeply grateful to Sandra Eickmeier for having provided us with the main code for the estimation and for her technical support and insights.

${ }^{10}$ The identification of the shocks never required more than 530 draws.
} 
first five years to display the cyclical pattern associated with the structural shocks. Both the median response and a 90 percent bootstrapped confidence band are estimated.

Two final points on identification are necessary. First, the identification strategy followed in this study, by construction, extracts supply and demand shocks that maximize the explained forecast error variance of the common components of ULCM and TOT. Second, the impulseresponse functions from a dataset containing only French variables were similar to those of the full sample, especially the supply shocks.

\section{ECONOMETRIC RESULTS}

Results are presented in the form of variance decomposition and impulse-response functions. Tables 3 and 4 show the variance decomposition and the forecast error variance of the common components (henceforth, error variance) of French and German variables explained by the two identified shocks to ULCM. Tables 5 and 6 show the same results for the two shocks to TOT. Figures in Annex II show the impulse-response functions of the French and German shocks to ULCM and TOT and their impact on French and German variables. These shocks suffice to explain up to 99 percent of the error variance of the common components of French and German ULCM over 20 quarters; similarly, these shocks explain up to 97 percent and 99 percent of the error variance of the common component of France and Germany TOT over 20 quarters, respectively. The variance shares of ULCM common components are high as they reach about 75 percent for both countries. In contrast, the variance shares of TOT are much smaller, especially for France: up to 10 percent and 42 percent for France and Germany, respectively. The later suggests that France's TOT are more influenced than Germany's by idiosyncratic factors. This is consistent with Kabundi and Nadal De Simone (2007) results: the TOT play a relatively lower role as channels of transmission of international disturbances in France than in Germany.

The demand shocks to ULCM and TOT are relatively more important than supply shocks for both countries. Supply and demand shocks have qualitatively broadly similar responses in France and in Germany. However, the quantitative effects as well as the adjustment process are significantly different.

In both countries, supply shocks to ULCM reduce output, private consumption, investment and the volume of exports of goods and services. Employment falls, despite some downward adjustment of real wages. The real exchange rate appreciates. The consumer price index, however, clearly falls in Germany while it is flat in France. The impulse-response functions show that the negative effect on output and on the volume of exports and employment of supply shocks is larger in France than in Germany (there seems to be a relatively larger downward rigidity of wages in France). The SMIC has a tendency to rise somewhat despite the fall in labor productivity. While the dollar value of exports to all destinations increases in Germany, this is not the case in France (e.g., exports to the United States clearly fall). The total increase in the dollar value of French exports is half that of German exports. The same 
results are evident in terms of the euro value of exports per product, especially for manufactures, transport equipment and mineral fuels and lubricants. France's euro value of exports is larger than Germany's for beverages and tobacco, animal and vegetable oils, and commodities and transactions n.e.c. Therefore, France adjusts relatively less via price and wage changes, and more via employment changes than Germany.

Demand shocks to ULCM affect France and Germany differently. A demand shock to ULCM in France produces a short-term small increase in output while employment, real wages and the consumer price index rise without denting productivity. Exports volume tends to increase somewhat while the real exchange rate tends to depreciate. However, as productivity declines, the process is reversed. The value of exports to all destinations and for all products falls. In Germany, the same shock has a much shorter positive impact on output and employment, i.e., less than a year. The consumer price index increases much less than in France; the real wage increase is short lived and gets undone already after $1 \frac{1 / 2}{2}$ years. Exports volume decrease and the real exchange rate appreciates. The value of exports is not much affected. So, when ULCM increase due to demand pressures, the German economy adjusts more rapidly and seems to display less cost inertia. The real exchange rate helps to offset the negative effects on output and exports while in the case of France it magnifies them.

TOT shocks affect France less than Germany and that difference is more marked following a demand shock than following a supply shock. Positive supply shocks to TOT increase output, investment, and the volume of exports of goods and services. Employment rises, but in France it does so only after real wages have fallen somewhat, given that labor productivity does not change much. In Germany, employment rises sooner and more than in France; the German increase in labor productivity is relatively larger and offsets the rise in real wages enough so that ULCM fall. The real exchange rate depreciation is similar in both economies in the medium run, but it takes longer to reach that level in France than in Germany. The consumer price index falls somewhat in France and is flat in Germany. The dollar value of exports to all destinations has a tendency to fall in France, but the fall is more pronounced in Germany due to the larger short-run exchange rate depreciation experienced by the economy. Exports by product in euros show no major clear patterns, but there is in general a slight increase. Summarizing the results, supply shocks that increase the terms of trade are more consistent with a persistent supply shock in Germany than in France.

Positive demand shocks to TOT result in a negative output effect in France and are clearly inflationary. The real effective exchange rate appreciates as productivity falls and ULCM rise. The SMIC rises despite the fall in labor productivity. The dollar value of French exports by destination increases, except the value of exports to the United States and to accession countries. The increase is, however, larger for Germany, except in terms of exports to China. The euro value of French exports increases less than German exports. In fact, France's exports are largely flat, except for crude materials, animal and vegetable oils, chemicals and commodities and transactions n.e.c. Overall, the results suggest that the French economy adapts less quickly to inflationary pressures on TOT as a result of a world demand. 


\section{A. The 1990s Until Today}

The variance shares of ULCM and TOT remain basically the same for France, i.e., around 73 and 10 percent, respectively, during the shorter sample covering the period 1993-2006 (Table 7). The demand shocks to ULCM and TOT are still more significant than supply shocks. The relative importance of the channels of transmission changed. The variance shares of labor productivity and total factor productivity doubled; the variance shares of real compensation of employees, employment, and the SMIC also increased, while the share of consumer prices fell. The results suggest that most variables (except the price level) have become less influenced by idiosyncratic factors. In addition, the error variances indicate that in the recent sample, the role of demand shocks has increased. Similarly, the fall in the variance share of exports from 81 percent to 70 percent suggests that the foreign sector idiosyncratic factors play a more significant role in recent times, a result consistent with the analysis above.

The relative more predominant role played by French idyosincratic factors becomes more obvious when France is compared with Germany. Germany had an increase in the variance share of ULCM and a slight decrease in the variance share of TOT. However, the price level, real compensation of employees, and productivity remained basically unchanged indicating that the role of idyosincratic factors did not change despite reunification. Idyosincratic factors have become more relevant for Germany in terms of the real effective exchange rate, as illustrated by a decline in its variance share. In contrast to France, German exports variance share increased significantly in the more recent period suggesting a more important role for common factors. Like for France, German demand shocks outweigh supply shocks.

\section{Conclusion ANd Policy Implications}

French economic activity is significantly affected by economic activity in the rest of the world. One key channel for the transmission of shocks across countries is international trade. In recent years, the export performance of the French economy relative of its own past and relative to a major trading partner, Germany, has deteriorated. Therefore, the question arises as to whether France is suffering from a competitiveness problem. So far, traditional variables explaining international trade have proved to be insufficient to elucidate the recent decline in France's export performance. Residuals from econometrically-estimated equations indicate a substantial drag on exports since 2001-02, not attributable to the standard global demand and price/cost factors. In addition, equilibrium exchange rate analysis indicates that France's real effective exchange rate is largely in line with fundamentals.

This study has found that the recent deterioration of French export performance does not seem to be the related to the "cycle" but to the trend growth of exports, which seems lower in the early 2000s than it was in the past. France's weaker export performance in the 2000s is reflected both in terms of geographical destination and in terms of product composition. 
Given the exposure of the French economy to the rest of the world as well as the known asymmetry in the transmission of disturbances, it was natural to analyze the response of the French economy to typical domestic and foreign shocks. The analysis of the effects of an increase in unit labor costs in manufacturing and of an increase in the terms of trade, suggests that the French economy is relatively less flexible to adjust than the German economy. Faced with an upward shift in unit labor costs, France adjusts relatively less via price and wage changes, and more via employment changes. The same differences are also evident when both countries are faced with an upward TOT shock. To the extent that the convergence of the SMIC operated between 2003 and 2006 represented a significant increase in unit labor costs, and to the extent that the country is a price taker in most of its exports, the study supports the view that the difficulties observed in the French foreign sector may be structural.

The importance of trade flows and relative price changes in the international transmission of disturbances - as well as the policy constraints imposed by the euro area — highlight the relevance of domestic price flexibility. The French economy would benefit from further structural reforms that increase its good, service, and labor markets' flexibility. This will matter for the magnitude of the real effective exchange rate changes, trade flows, and the size of the current account balance that will be necessary to accommodate the given disturbance.

Similarly, the analysis highlights the importance of measures that increase productivity and, in particular, the desirability of avoiding SMIC adjustments unrelated to productivity. 
Figure 1. Cyclical Part
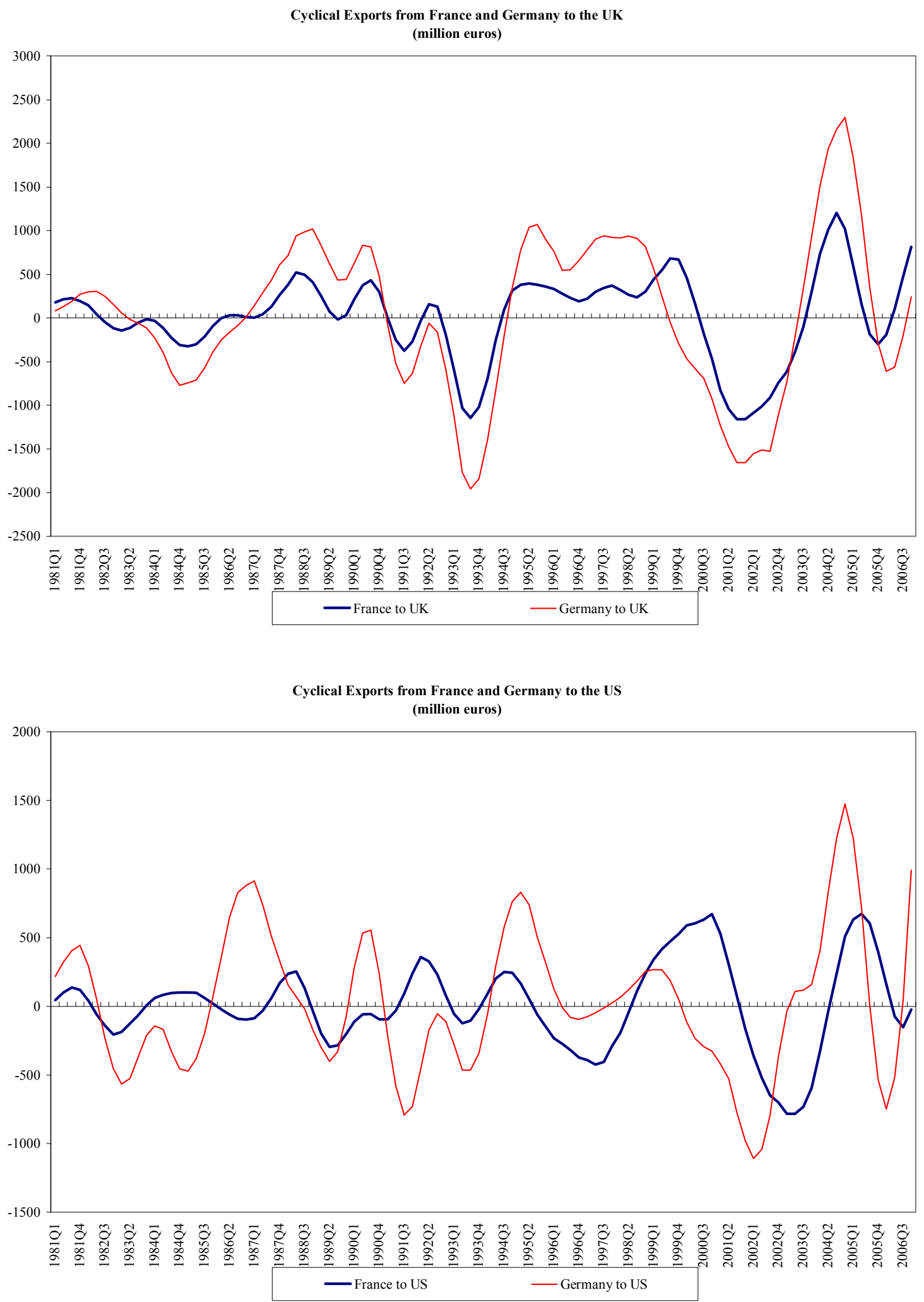
Figure 1. Cyclical Part (continued)
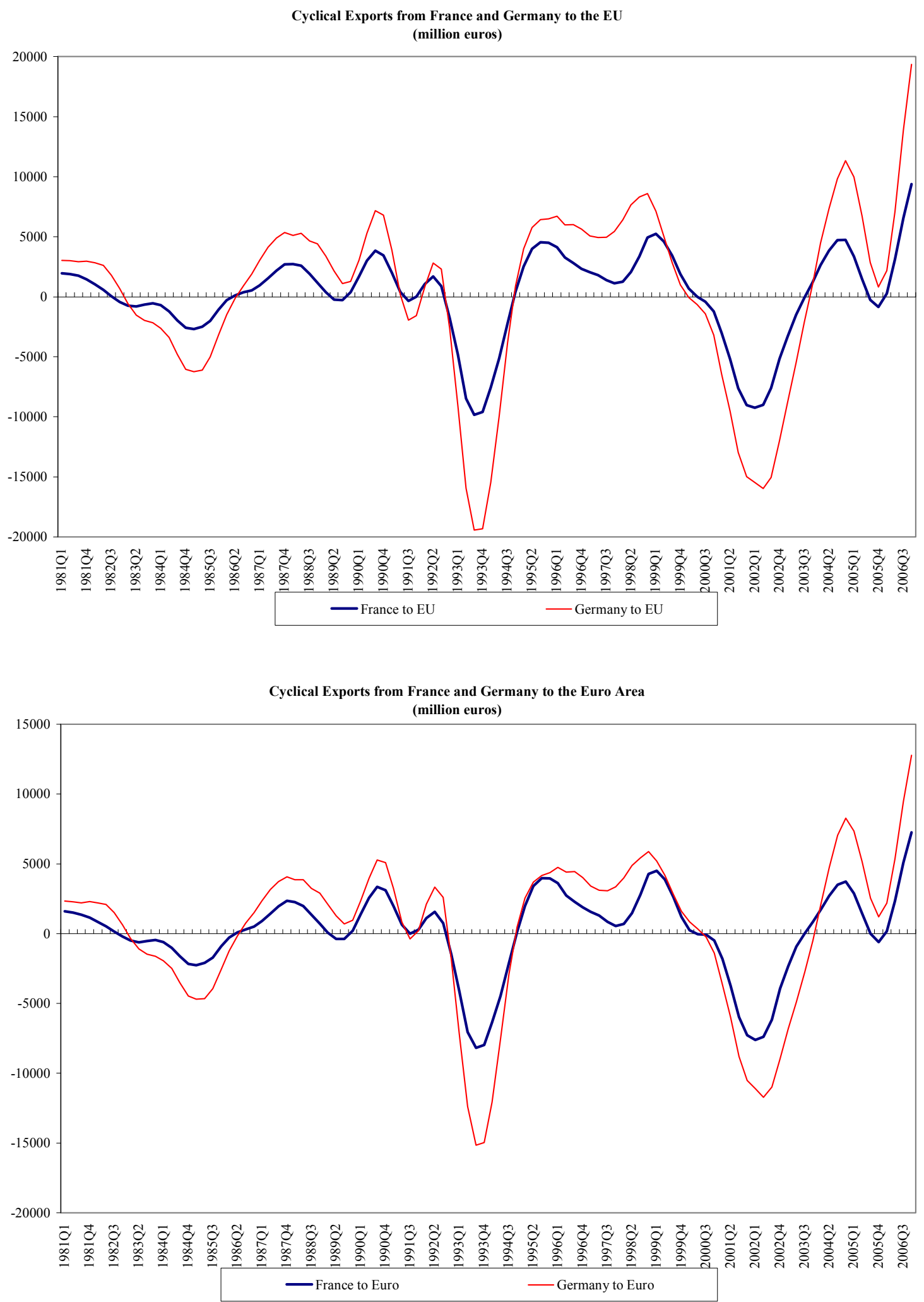
Figure 1. Cyclical Part (concluded)

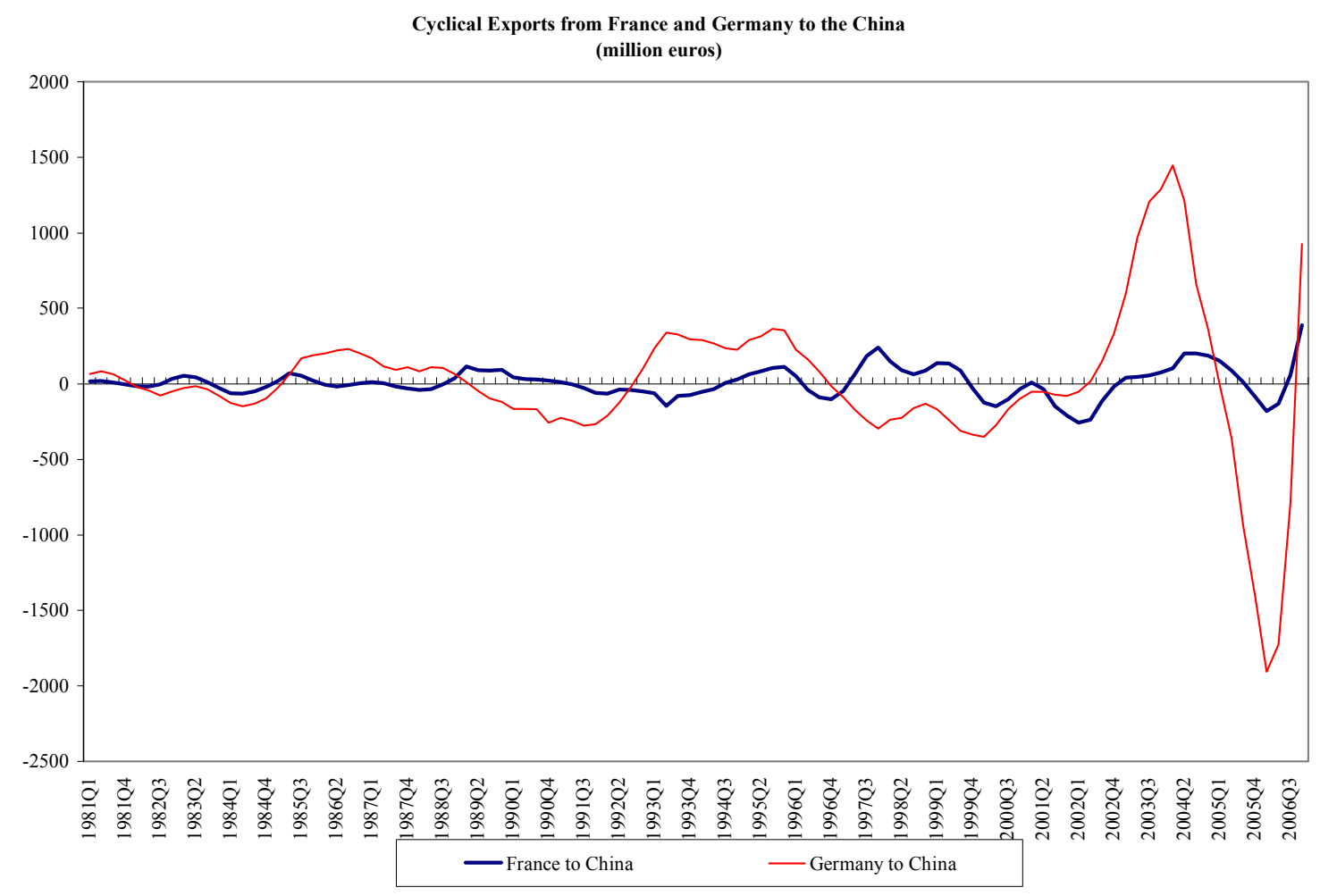


Figure 2. Trend Part

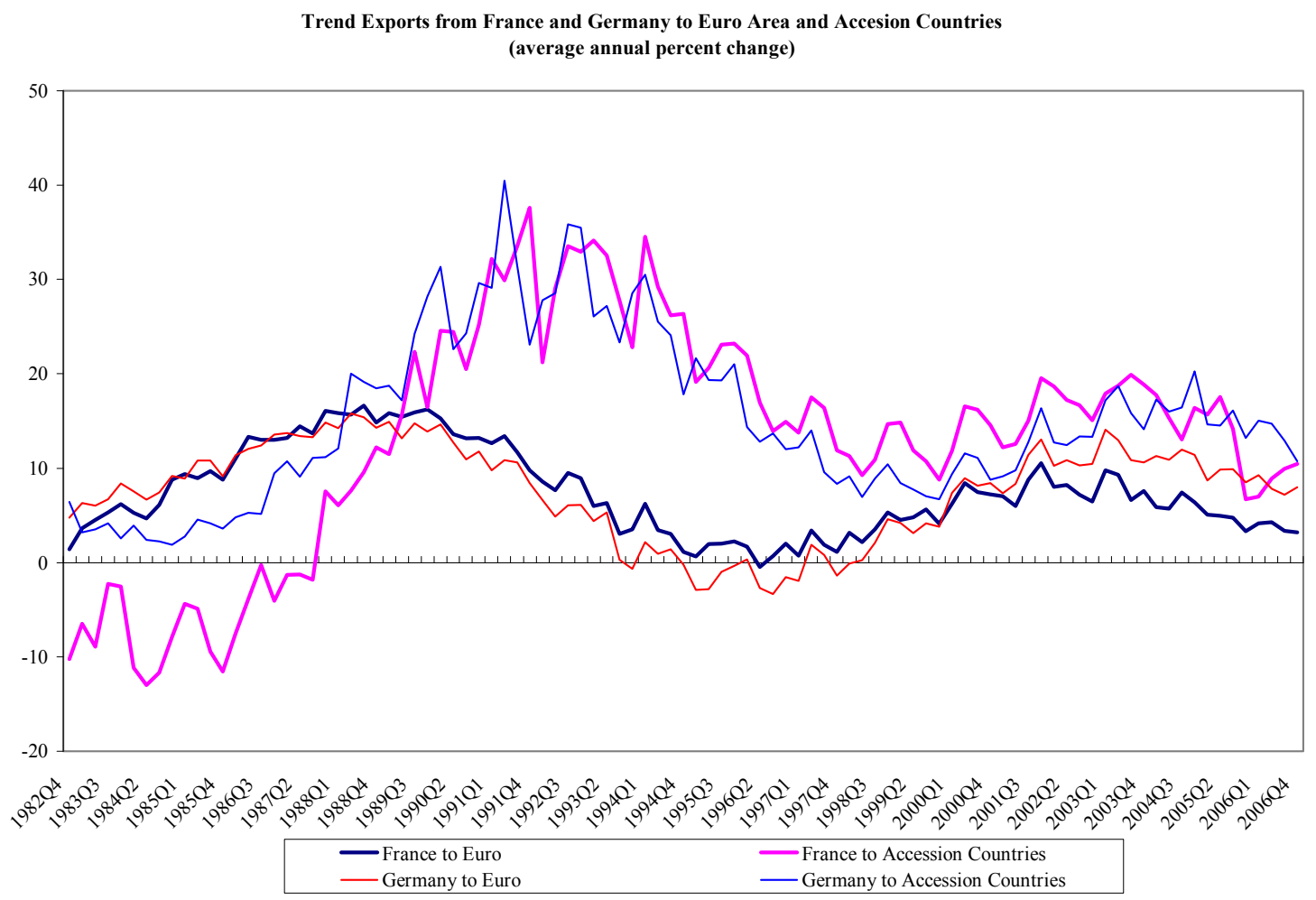

Trend Exports from France and Germany to Japan and China (average annual percent change)

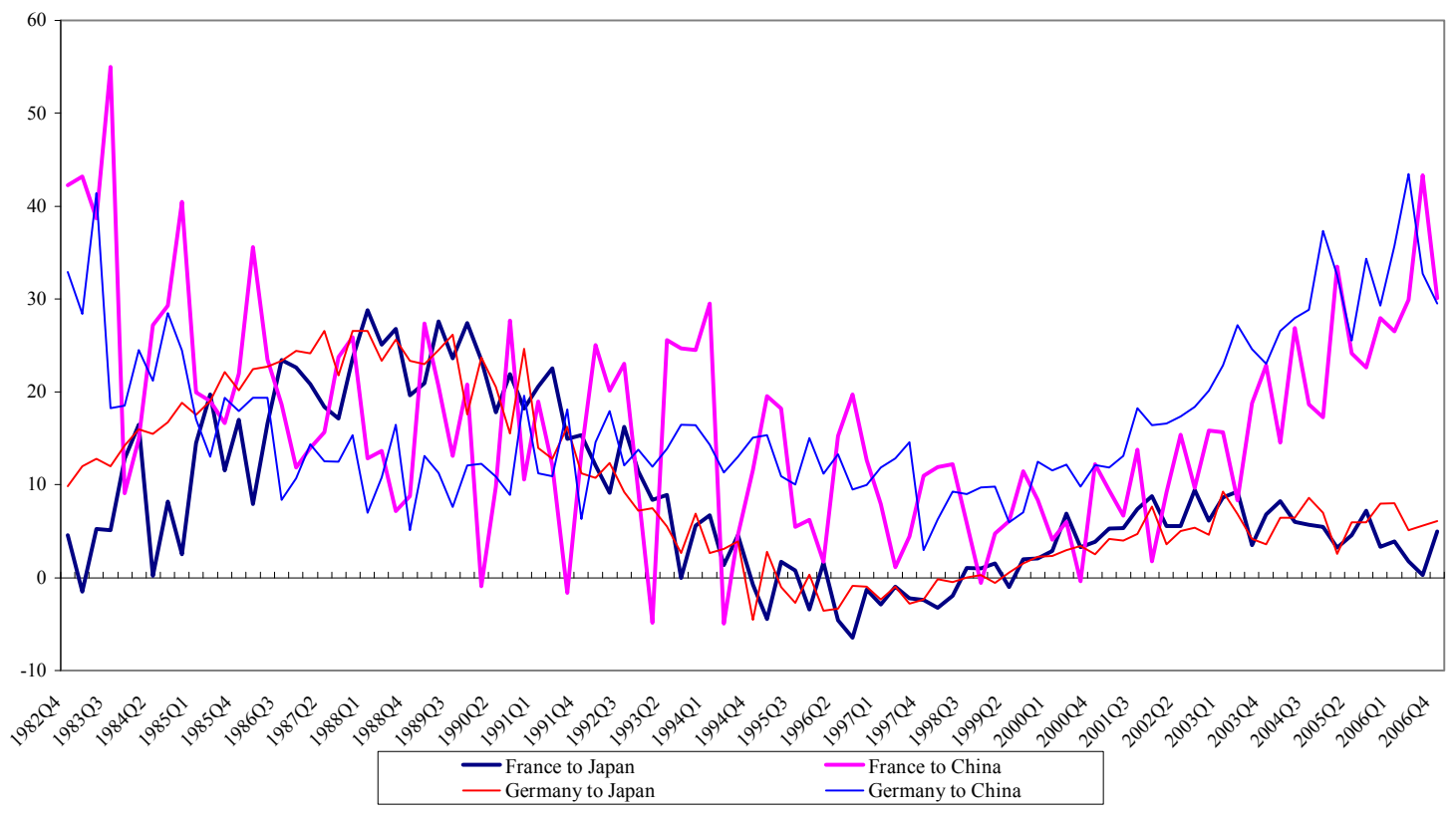


Figure 2. Trend Part (continued)

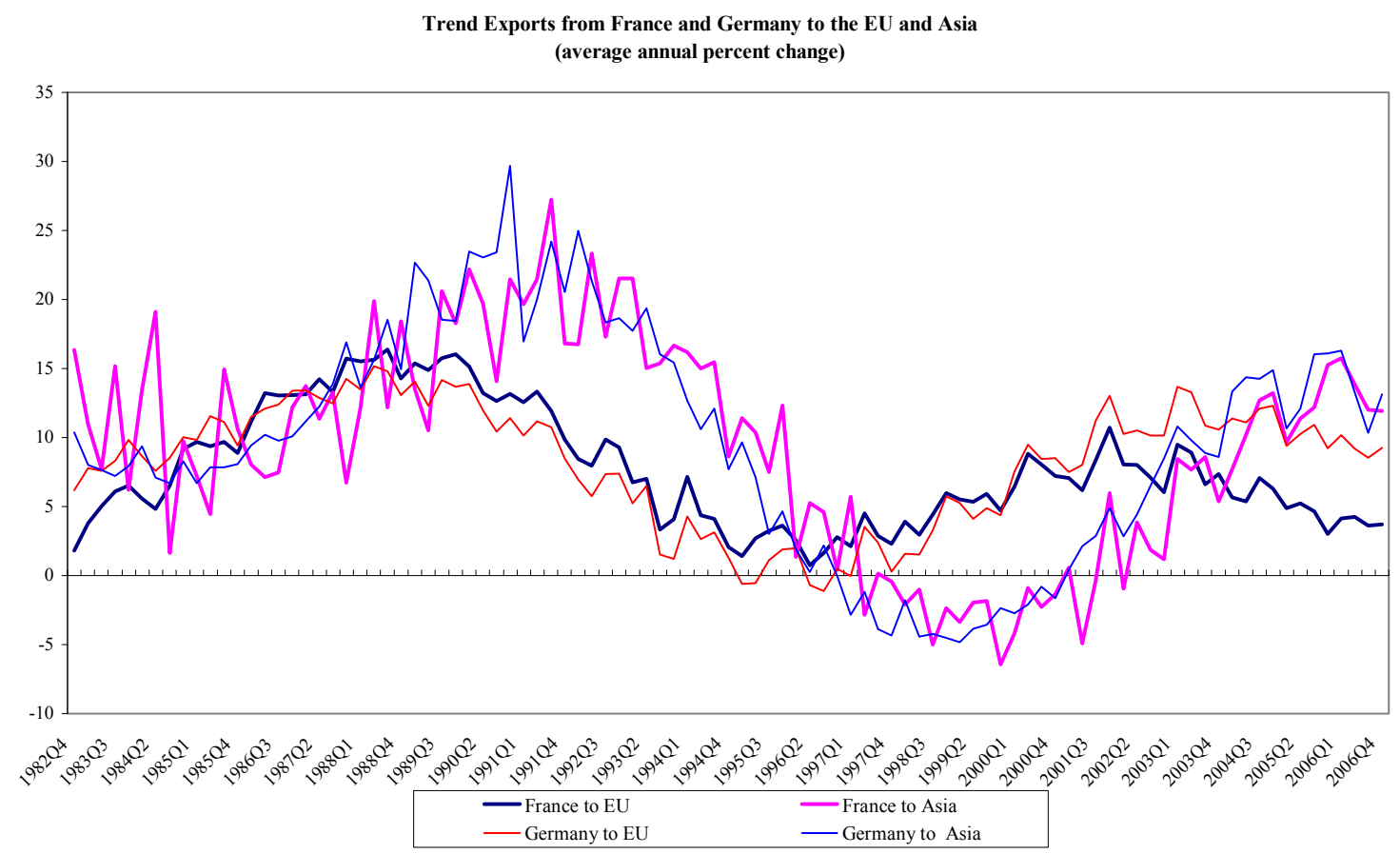

Trend Exports from France and Germany to the US and the UK (average annual percent change)

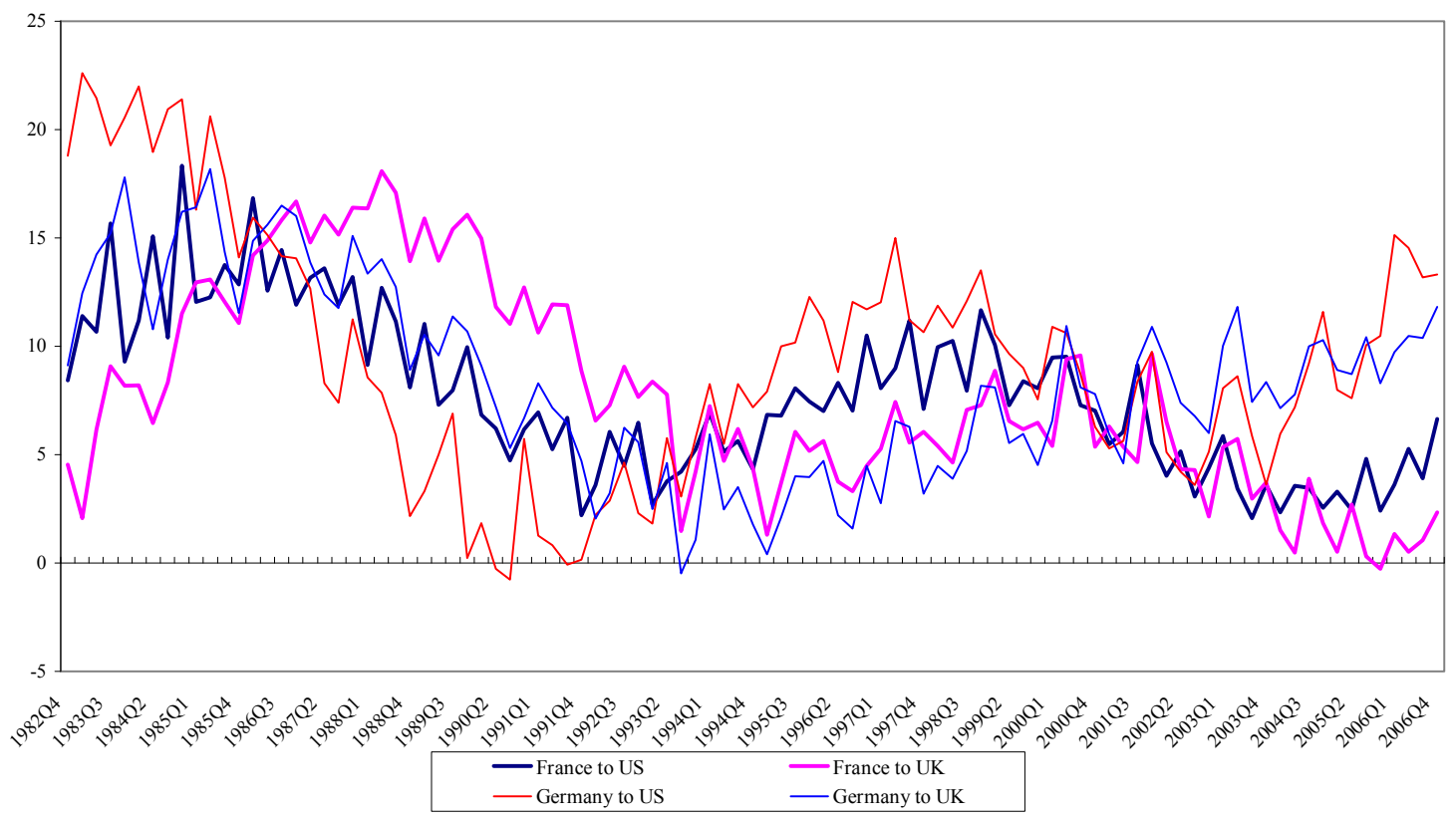


20

Figure 2. Trend Part (concluded)

Trend Exports from France and Germany to Euro Area and Ascension Countries (average annual percent change)

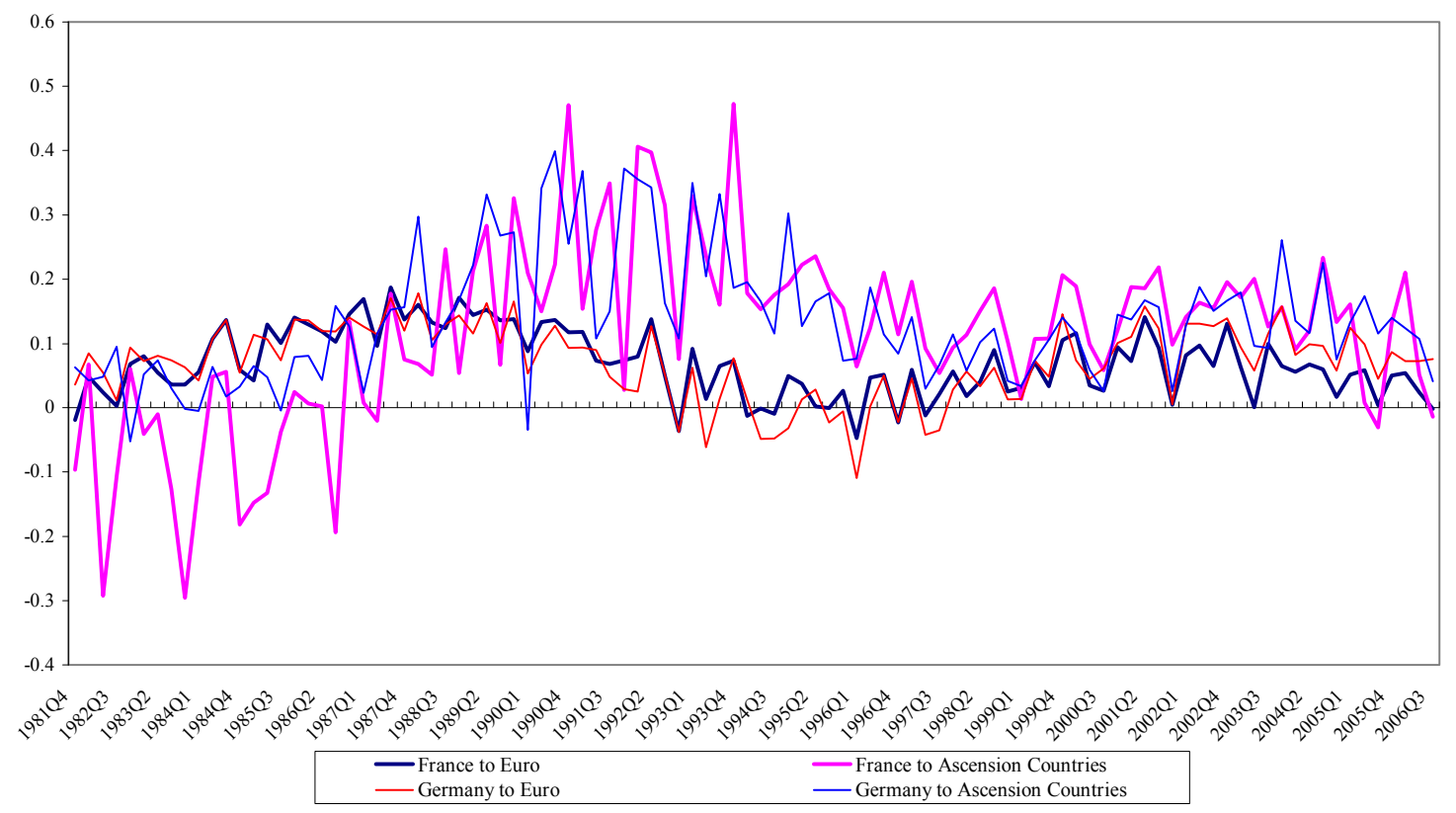


Table 1. Trend Exports per Destination 1/ (Average annual percent change)

\begin{tabular}{|c|c|c|c|c|c|}
\hline & & $1980-2006$ & 1980-1989 & 1990-1999 & $2000-2006$ \\
\hline \multirow{9}{*}{ 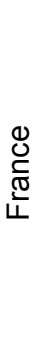 } & France to EU & 1.7 & 2.3 & 1.3 & 1.2 \\
\hline & France to Asia & 2.1 & 2.4 & 1.7 & 1.9 \\
\hline & France to Japan & 1.9 & 3.5 & 1.0 & 1.5 \\
\hline & France to China & 3.8 & 5.6 & 2.4 & 3.8 \\
\hline & France to Euro & 1.6 & 2.3 & 1.2 & 1.2 \\
\hline & Franceto Accession Countries & 2.6 & 0.0 & 4.9 & 2.6 \\
\hline & France to United States & 1.9 & 2.8 & 1.9 & 1.1 \\
\hline & France to United Kingdom & 1.8 & 2.7 & 1.6 & 0.6 \\
\hline & France to ROW & 0.9 & 0.3 & 0.6 & 1.7 \\
\hline \multirow{9}{*}{ 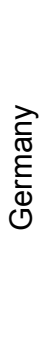 } & Germany to EU & 1.9 & 2.5 & 0.9 & 2.2 \\
\hline & Germany to Asia & 2.3 & 2.6 & 1.1 & 2.7 \\
\hline & Germany to Japan & 2.2 & 3.9 & 0.3 & 1.5 \\
\hline & Germany to China & 3.7 & 3.2 & 2.5 & 5.3 \\
\hline & Germany to Euro & 1.8 & 2.5 & 0.6 & 2.1 \\
\hline & Germany to Accession Countries & 3.2 & 2.1 & 4.4 & 3.0 \\
\hline & Germany to United States & 2.3 & 2.8 & 1.9 & 2.2 \\
\hline & Germany to United Kingdom & 2.0 & 3.0 & 1.2 & 1.8 \\
\hline & Germany to ROW & 1.6 & 1.3 & 0.6 & 3.2 \\
\hline
\end{tabular}

$1 /$ Numbers in bold indicate a higher growth rate of French trend exports.

Table 2. Trend Exports per Product SITC 1/ (Average annual percent change)

\begin{tabular}{|c|c|c|c|c|c|}
\hline & & $1980-2006$ & 1980-1989 & 1990-1999 & $2000-2006$ \\
\hline \multirow{11}{*}{ 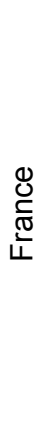 } & Total & 1.5 & 2.1 & 1.0 & 1.4 \\
\hline & Food and live animal - SITC 0 & 0.9 & 1.3 & 0.7 & 0.5 \\
\hline & Beverages and tobacco - SITC 1 & 1.5 & 2.4 & 0.8 & 1.4 \\
\hline & Crude materials, inedible, except fuels - SITC 2 & 1.2 & 2.1 & -0.3 & 2.3 \\
\hline & Mineral fuels, lubricants and related materials - SITC 3 & 1.5 & -0.1 & 1.5 & 3.8 \\
\hline & Animal and vegetable oils, fats and waxes - SITC 4 & 1.2 & 0.8 & 0.6 & 2.3 \\
\hline & Chemicals and related products - SITC 5 & 2.1 & 2.7 & 1.4 & 2.2 \\
\hline & Manufactured goods - SITC 6 & 1.2 & 1.5 & 0.8 & 1.4 \\
\hline & Machinery and transport equipment - SITC 7 & 1.7 & 2.6 & 1.2 & 1.1 \\
\hline & Miscellaneous manufactured articles - SITC 8 & 1.7 & 2.5 & 1.0 & 1.7 \\
\hline & Commodities and transactions - SITC 9 & -1.5 & -2.8 & -7.4 & 8.2 \\
\hline \multirow{11}{*}{ 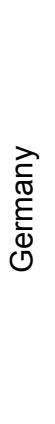 } & Total & 1.9 & 2.3 & 1.0 & 2.5 \\
\hline & Food and live animal - SITC 0 & 1.5 & 1.8 & 0.7 & 2.1 \\
\hline & Beverages and tobacco - SITC 1 & 2.1 & 2.3 & 1.4 & 3.2 \\
\hline & Crude materials, inedible, except fuels - SITC 2 & 1.8 & 2.1 & 0.5 & 2.8 \\
\hline & Mineral fuels, lubricants and related materials - SITC 3 & 1.3 & -1.3 & 0.6 & 4.7 \\
\hline & Animal and vegetable oils, fats and waxes - SITC 4 & 0.7 & 0.5 & 1.1 & 0.7 \\
\hline & Chemicals and related products - SITC 5 & 2.0 & 2.3 & 1.1 & 2.8 \\
\hline & Manufactured goods - SITC 6 & 1.6 & 2.0 & 0.6 & 2.4 \\
\hline & Machinery and transport equipment - SITC 7 & 2.0 & 2.5 & 1.1 & 2.4 \\
\hline & Miscellaneous manufactured articles - SITC 8 & 2.0 & 2.9 & 0.7 & 2.5 \\
\hline & Commodities and transactions - SITC 9 & 3.0 & 1.3 & 3.5 & 2.9 \\
\hline
\end{tabular}

1/ Numbers in bold indicate a higher growth rate of French trend exports. 
Table 3. Forecast Error Variance of the Common Components of French Variables Explained by the Supply and Demand Shocks to Unit Labor Costs in Manufacturing, 1980-2006 1/

\begin{tabular}{|c|c|c|c|c|c|c|c|}
\hline & \multirow{2}{*}{$\begin{array}{r}\text { Variance Shares } \\
\text { of the Common } \\
\text { Components }\end{array}$} & \multirow{2}{*}{$\begin{array}{l}\text { Supply } \\
\text { Shocks }\end{array}$} & \multicolumn{2}{|c|}{ Confidence Intervals } & \multirow{2}{*}{$\begin{array}{r}\text { Demand } \\
\text { Shock }\end{array}$} & \multicolumn{2}{|c|}{ Confidence Intervals } \\
\hline & & & Lower Bound & Upper Bound & & Lower Bound & Upper Bound \\
\hline 1 GDP & 0.81 & 0.75 & 0.16 & 0.90 & 0.12 & 0.04 & 0.71 \\
\hline 2 Personal consumption expenditure & 0.51 & 0.29 & 0.04 & 0.75 & 0.32 & 0.08 & 0.76 \\
\hline 3 Private investment & 0.86 & 0.38 & 0.03 & 0.88 & 0.44 & 0.06 & 0.89 \\
\hline 4 Employment & 0.70 & 0.74 & 0.20 & 0.89 & 0.08 & 0.03 & 0.58 \\
\hline 5 Productivity & 0.35 & 0.83 & 0.10 & 0.92 & 0.13 & 0.04 & 0.79 \\
\hline 6 Unit labor cost of the manufacturing sector & 0.74 & 0.07 & 0.02 & 0.62 & 0.93 & 0.36 & 0.98 \\
\hline 7 Government savings & 0.87 & 0.43 & 0.03 & 0.89 & 0.43 & 0.05 & 0.90 \\
\hline 8 Consumer confidence & 0.46 & 0.13 & 0.02 & 0.79 & 0.87 & 0.15 & 0.97 \\
\hline 9 Industrial confidence & 0.47 & 0.15 & 0.04 & 0.53 & 0.54 & 0.20 & 0.84 \\
\hline 10 Consumer prices & 0.90 & 0.05 & 0.00 & 0.60 & 0.83 & 0.30 & 0.94 \\
\hline 11 Short-term interest rates & 0.58 & 0.90 & 0.22 & 0.92 & 0.05 & 0.02 & 0.57 \\
\hline 12 Long-term interest rates & 0.59 & 0.41 & 0.06 & 0.80 & 0.07 & 0.01 & 0.47 \\
\hline $13 \mathrm{M} 2$ or M3 & 0.64 & 0.18 & 0.03 & 0.63 & 0.10 & 0.02 & 0.48 \\
\hline 14 Stock prices & 0.77 & 0.49 & 0.01 & 0.82 & 0.22 & 0.01 & 0.81 \\
\hline 15 Real compensation of employees & 0.62 & 0.77 & 0.24 & 0.89 & 0.07 & 0.03 & 0.54 \\
\hline 16 SMIC & 0.61 & 0.11 & 0.01 & 0.61 & 0.81 & 0.30 & 0.95 \\
\hline 17 TFP & 0.47 & 0.20 & 0.06 & 0.64 & 0.47 & 0.12 & 0.80 \\
\hline 18 Exports total & 0.81 & 0.92 & 0.15 & 0.92 & 0.04 & 0.01 & 0.60 \\
\hline 19 Imports total & 0.79 & 0.35 & 0.04 & 0.88 & 0.58 & 0.08 & 0.93 \\
\hline 20 Terms of trade & 0.10 & 0.48 & 0.01 & 0.77 & 0.06 & 0.02 & 0.65 \\
\hline 21 Real effective exchange & 0.79 & 0.61 & 0.01 & 0.91 & 0.31 & 0.01 & 0.83 \\
\hline 22 Current account balance & 0.42 & 0.33 & 0.04 & 0.83 & 0.60 & 0.08 & 0.92 \\
\hline 23 FDI out & 0.72 & 0.56 & 0.02 & 0.88 & 0.30 & 0.02 & 0.88 \\
\hline 24 FDI in & 0.52 & 0.55 & 0.02 & 0.87 & 0.24 & 0.02 & 0.85 \\
\hline 25 Exports to Euro & 0.83 & 0.26 & 0.01 & 0.72 & 0.57 & 0.06 & 0.89 \\
\hline 26 Exports to EU & 0.84 & 0.28 & 0.01 & 0.72 & 0.58 & 0.07 & 0.90 \\
\hline 27 Exports to EU accession ctrys & 0.69 & 0.11 & 0.00 & 0.68 & 0.68 & 0.20 & 0.91 \\
\hline 28 Exports to United States & 0.44 & 0.44 & 0.01 & 0.74 & 0.17 & 0.00 & 0.74 \\
\hline 29 Exports to United Kingdom & 0.74 & 0.38 & 0.01 & 0.81 & 0.57 & 0.07 & 0.93 \\
\hline 30 Exports to Japan & 0.77 & 0.45 & 0.03 & 0.74 & 0.33 & 0.04 & 0.76 \\
\hline 31 Exports to China,P.R.: Mainland & 0.16 & 0.43 & 0.02 & 0.81 & 0.44 & 0.04 & 0.86 \\
\hline 32 Exports to Asia & 0.56 & 0.35 & 0.03 & 0.76 & 0.51 & 0.09 & 0.87 \\
\hline 33 Exports to ROW & 0.64 & 0.37 & 0.02 & 0.81 & 0.60 & 0.12 & 0.95 \\
\hline 34 EXP SITC Total & 0.90 & 0.64 & 0.01 & 0.69 & 0.09 & 0.09 & 0.88 \\
\hline 35 EXP SITC 0: Food and live animal & 0.64 & 0.77 & 0.01 & 0.85 & 0.02 & 0.02 & 0.85 \\
\hline 36 EXP SITC 1: Beverages and tobacco & 0.87 & 0.67 & 0.01 & 0.80 & 0.02 & 0.02 & 0.87 \\
\hline 37 EXP SITC 2: Crude materials, inefible, except fuels & 0.91 & 0.71 & 0.03 & 0.67 & 0.11 & 0.14 & 0.85 \\
\hline 38 EXP SITC 3: Mineral fuels, lubricants and related materials & 0.59 & 0.15 & 0.02 & 0.87 & 0.81 & 0.07 & 0.95 \\
\hline 39 EXP SITC 4: Animal and vegetable oils, fats and waxes & 0.63 & 0.28 & 0.04 & 0.42 & 0.04 & 0.01 & 0.33 \\
\hline 40 EXP SITC 5: Chemicals and related profucts, n.e.s & 0.92 & 0.75 & 0.02 & 0.75 & 0.05 & 0.05 & 0.83 \\
\hline 41 EXP SITC 6: Manufactured goods & 0.92 & 0.71 & 0.02 & 0.71 & 0.09 & 0.12 & 0.88 \\
\hline 42 EXP SITC 7: Machinery and transport equipment & 0.87 & 0.51 & 0.01 & 0.62 & 0.12 & 0.11 & 0.85 \\
\hline 43 EXP SITC 8: Miscellaneous manufactured articles & 0.87 & 0.64 & 0.01 & 0.75 & 0.05 & 0.05 & 0.87 \\
\hline 44 EXP SITC 9: Commodities and transactions n.e.c & 0.24 & 0.42 & 0.03 & 0.90 & 0.37 & 0.01 & 0.65 \\
\hline
\end{tabular}

1/ Forecast horizon is 20 quarters and refers to the levels of the series. Confidence intervals are constructed using bootstrapping methods. 
Table 4. Forecast Error Variance of the Common Components of German Variables Explained by the Supply and Demand Shocks to Unit Labor Costs in Manufacturing, 1980-2006 1/

\begin{tabular}{|c|c|c|c|c|c|c|c|}
\hline & \multirow{2}{*}{$\begin{array}{r}\text { Variance Shares } \\
\text { of the Common } \\
\text { Components }\end{array}$} & \multirow{2}{*}{$\begin{array}{l}\text { Supply } \\
\text { Shocks }\end{array}$} & \multicolumn{2}{|c|}{ Confidence Intervals } & \multirow{2}{*}{$\begin{array}{l}\text { Demand } \\
\text { Shock }\end{array}$} & \multicolumn{2}{|c|}{ Confidence Intervals } \\
\hline & & & Lower Bound & Upper Bound & & Lower Bound & Upper Bound \\
\hline 1 GDP & 0.70 & 0.13 & 0.01 & 0.83 & 0.82 & 0.11 & 0.86 \\
\hline 2 Personal consumption expenditure & 0.34 & 0.02 & 0.00 & 0.51 & 0.84 & 0.20 & 0.85 \\
\hline 3 Private investment & 0.93 & 0.05 & 0.02 & 0.58 & 0.86 & 0.28 & 0.90 \\
\hline 4 Employment & 0.77 & 0.05 & 0.01 & 0.69 & 0.79 & 0.11 & 0.83 \\
\hline 5 Productivity & 0.36 & 0.30 & 0.03 & 0.89 & 0.45 & 0.01 & 0.62 \\
\hline 6 Unit labor cost of the manufacturing sector & 0.73 & 0.34 & 0.00 & 0.62 & 0.66 & 0.35 & 0.96 \\
\hline 7 Government savings & 0.70 & 0.01 & 0.01 & 0.62 & 0.88 & 0.20 & 0.88 \\
\hline 8 Consumer confidence & 0.32 & 0.02 & 0.01 & 0.51 & 0.89 & 0.36 & 0.93 \\
\hline 9 Industrial confidence & 0.54 & 0.25 & 0.04 & 0.48 & 0.62 & 0.30 & 0.87 \\
\hline 10 Consumer prices & 0.92 & 0.69 & 0.02 & 0.86 & 0.03 & 0.01 & 0.77 \\
\hline 1 Short-term interest rates & 0.76 & 0.07 & 0.02 & 0.77 & 0.88 & 0.15 & 0.89 \\
\hline 2 Long-term interest rates & 0.54 & 0.38 & 0.04 & 0.76 & 0.43 & 0.02 & 0.64 \\
\hline $3 \mathrm{M} 2$ or $\mathrm{M} 3$ & 0.47 & 0.30 & 0.01 & 0.79 & 0.51 & 0.05 & 0.62 \\
\hline 4 Stock prices & 0.69 & 0.01 & 0.01 & 0.55 & 0.87 & 0.22 & 0.86 \\
\hline 15 Real compensation of employees & 0.54 & 0.61 & 0.03 & 0.89 & 0.31 & 0.04 & 0.50 \\
\hline 6 Exports total & 0.69 & 0.15 & 0.01 & 0.79 & 0.81 & 0.14 & 0.87 \\
\hline 17 Imports total & 0.84 & 0.04 & 0.01 & 0.60 & 0.89 & 0.28 & 0.91 \\
\hline 8 Terms of trade & 0.42 & 0.70 & 0.06 & 0.91 & 0.05 & 0.02 & 0.75 \\
\hline 19 Real effective exchange & 0.74 & 0.21 & 0.03 & 0.88 & 0.61 & 0.02 & 0.81 \\
\hline 20 Current account balance & 0.17 & 0.05 & 0.01 & 0.62 & 0.01 & 0.02 & 0.38 \\
\hline 21 FDI out & 0.52 & 0.32 & 0.01 & 0.60 & 0.40 & 0.11 & 0.85 \\
\hline 22 FDI in & 0.15 & 0.01 & 0.01 & 0.60 & 0.86 & 0.20 & 0.88 \\
\hline 23 Exports to Euro & 0.89 & 0.52 & 0.06 & 0.87 & 0.10 & 0.01 & 0.60 \\
\hline 24 Exports to EU & 0.90 & 0.52 & 0.07 & 0.87 & 0.12 & 0.01 & 0.56 \\
\hline 25 Exports to EU accession ctrys & 0.64 & 0.57 & 0.02 & 0.85 & 0.04 & 0.00 & 0.62 \\
\hline 26 Exports to United States & 0.49 & 0.84 & 0.06 & 0.91 & 0.02 & 0.01 & 0.51 \\
\hline 27 Exports to United Kingdom & 0.87 & 0.44 & 0.04 & 0.87 & 0.28 & 0.02 & 0.42 \\
\hline 8 Exports to Japan & 0.81 & 0.63 & 0.04 & 0.92 & 0.19 & 0.03 & 0.48 \\
\hline 29 Exports to China,P.R.: Mainland & 0.69 & 0.22 & 0.01 & 0.64 & 0.47 & 0.07 & 0.72 \\
\hline 30 Exports to Asia & 0.76 & 0.56 & 0.03 & 0.90 & 0.29 & 0.03 & 0.44 \\
\hline 1 Exports to ROW & 0.92 & 0.48 & 0.05 & 0.86 & 0.13 & 0.01 & 0.54 \\
\hline 2 EXP SITC Total & 0.92 & 0.37 & 0.05 & 0.82 & 0.44 & 0.01 & 0.46 \\
\hline 3 EXP SITC 0: Food and live animal & 0.92 & 0.38 & 0.03 & 0.81 & 0.36 & 0.00 & 0.42 \\
\hline 4 EXP SITC 1: Beverages and tobacco & 0.58 & 0.37 & 0.01 & 0.79 & 0.21 & 0.00 & 0.32 \\
\hline 5 EXP SITC 2: Crude materials, inefible, except fuels & 0.81 & 0.36 & 0.06 & 0.87 & 0.57 & 0.03 & 0.66 \\
\hline 36 EXP SITC 3: Mineral fuels, lubricants and related materials & 0.64 & 0.08 & 0.02 & 0.55 & 0.86 & 0.41 & 0.92 \\
\hline 37 EXP SITC 4: Animal and vegetable oils, fats and waxes & 0.41 & 0.28 & 0.01 & 0.66 & 0.21 & 0.04 & 0.44 \\
\hline 8 EXP SITC 5: Chemicals and related profucts, n.e.s & 0.89 & 0.47 & 0.07 & 0.86 & 0.41 & 0.01 & 0.46 \\
\hline 39 EXP SITC 6: Manufactured goods & 0.91 & 0.40 & 0.06 & 0.84 & 0.45 & 0.01 & 0.50 \\
\hline 10 EXP SITC 7: Machinery and transport equipment & 0.89 & 0.37 & 0.03 & 0.81 & 0.39 & 0.00 & 0.41 \\
\hline 11 EXP SITC 8: Miscellaneous manufactured articles & 0.92 & 0.36 & 0.03 & 0.81 & 0.36 & 0.00 & 0.41 \\
\hline 12 EXP SITC 9: Commodities and transactions n.e.c & 0.08 & 0.09 & 0.01 & 0.68 & 0.68 & 0.03 & 0.74 \\
\hline
\end{tabular}

1/ Forecast horizon is 20 quarters and refers to the levels of the series. Confidence intervals are constructed using bootstrapping methods. 
Table 5. Forecast Error Variance of the Common Components of French Variables Explained by the Supply and Demand Shocks to Terms of Trade, 1980-2006 1/

\begin{tabular}{|c|c|c|c|c|c|c|c|}
\hline & \multirow{2}{*}{$\begin{array}{r}\text { Variance Shares } \\
\text { of the Common } \\
\text { Components }\end{array}$} & \multirow{2}{*}{$\begin{array}{l}\text { Supply } \\
\text { Shocks }\end{array}$} & \multicolumn{2}{|c|}{ Confidence Intervals } & \multirow{2}{*}{$\begin{array}{l}\text { Demand } \\
\text { Shock }\end{array}$} & \multicolumn{2}{|c|}{ Confidence Intervals } \\
\hline & & & Lower Bound & Upper Bound & & Lower Bound & Upper Bound \\
\hline 1 GDP & 0.81 & 0.46 & 0.08 & 0.83 & 0.08 & 0.05 & 0.79 \\
\hline 2 Personal consumption expenditure & 0.51 & 0.61 & 0.12 & 0.83 & 0.24 & 0.04 & 0.68 \\
\hline 3 Private investment & 0.86 & 0.33 & 0.02 & 0.82 & 0.43 & 0.05 & 0.87 \\
\hline 4 Employment & 0.70 & 0.39 & 0.08 & 0.81 & 0.05 & 0.06 & 0.75 \\
\hline 5 Productivity & 0.35 & 0.37 & 0.02 & 0.80 & 0.14 & 0.07 & 0.87 \\
\hline 6 Unit labor cost of the manufacturing sector & 0.74 & 0.07 & 0.02 & 0.74 & 0.22 & 0.00 & 0.53 \\
\hline 7 Government savings & 0.87 & 0.29 & 0.01 & 0.81 & 0.46 & 0.06 & 0.88 \\
\hline 8 Consumer confidence & 0.46 & 0.18 & 0.02 & 0.80 & 0.25 & 0.01 & 0.64 \\
\hline 9 Industrial confidence & 0.47 & 0.38 & 0.11 & 0.81 & 0.04 & 0.00 & 0.38 \\
\hline 0 Consumer prices & 0.90 & 0.01 & 0.00 & 0.60 & 0.26 & 0.00 & 0.58 \\
\hline 1 Short-term interest rates & 0.58 & 0.19 & 0.02 & 0.72 & 0.03 & 0.05 & 0.79 \\
\hline 2 Long-term interest rates & 0.59 & 0.25 & 0.02 & 0.76 & 0.12 & 0.02 & 0.47 \\
\hline $3 \mathrm{M} 2$ or $\mathrm{M} 3$ & 0.64 & 0.26 & 0.02 & 0.66 & 0.16 & 0.03 & 0.62 \\
\hline 4 Stock prices & 0.77 & 0.02 & 0.00 & 0.55 & 0.63 & 0.24 & 0.90 \\
\hline 5 Real compensation of employees & 0.62 & 0.25 & 0.03 & 0.70 & 0.05 & 0.09 & 0.80 \\
\hline 6 SMIC & 0.61 & 0.02 & 0.01 & 0.61 & 0.20 & 0.00 & 0.48 \\
\hline 7 TFP & 0.47 & 0.68 & 0.26 & 0.89 & 0.09 & 0.02 & 0.44 \\
\hline 8 Exports total & 0.81 & 0.14 & 0.01 & 0.73 & 0.03 & 0.02 & 0.71 \\
\hline 9 Imports total & 0.79 & 0.37 & 0.03 & 0.84 & 0.32 & 0.03 & 0.78 \\
\hline 0 Terms of trade & 0.10 & 0.13 & 0.03 & 0.50 & 0.82 & 0.47 & 0.96 \\
\hline 1 Real effective exchange & 0.79 & 0.00 & 0.00 & 0.42 & 0.10 & 0.00 & 0.46 \\
\hline 2 Current account balance & 0.42 & 0.47 & 0.08 & 0.85 & 0.17 & 0.02 & 0.63 \\
\hline 3 FDI out & 0.72 & 0.11 & 0.00 & 0.65 & 0.54 & 0.16 & 0.89 \\
\hline 4 FDI in & 0.52 & 0.08 & 0.00 & 0.64 & 0.63 & 0.22 & 0.91 \\
\hline 5 Exports to Euro & 0.83 & 0.05 & 0.01 & 0.69 & 0.16 & 0.00 & 0.33 \\
\hline 6 Exports to EU & 0.84 & 0.04 & 0.01 & 0.69 & 0.16 & 0.00 & 0.33 \\
\hline 7 Exports to EU accession ctrys & 0.69 & 0.00 & 0.00 & 0.54 & 0.24 & 0.00 & 0.54 \\
\hline 8 Exports to United States & 0.44 & 0.01 & 0.00 & 0.46 & 0.52 & 0.23 & 0.86 \\
\hline 9 Exports to United Kingdom & 0.74 & 0.04 & 0.01 & 0.70 & 0.12 & 0.00 & 0.37 \\
\hline 0 Exports to Japan & 0.77 & 0.18 & 0.03 & 0.68 & 0.04 & 0.02 & 0.60 \\
\hline 1 Exports to China,P.R.: Mainland & 0.16 & 0.08 & 0.02 & 0.68 & 0.08 & 0.01 & 0.47 \\
\hline 2 Exports to Asia & 0.56 & 0.13 & 0.03 & 0.76 & 0.09 & 0.00 & 0.43 \\
\hline 3 Exports to ROW & 0.64 & 0.05 & 0.02 & 0.69 & 0.11 & 0.00 & 0.35 \\
\hline 4 EXP SITC Total & 0.90 & 0.39 & 0.01 & 0.69 & 0.03 & 0.01 & 0.32 \\
\hline 5 EXP SITC 0: Food and live animal & 0.64 & 0.25 & 0.01 & 0.53 & 0.10 & 0.01 & 0.51 \\
\hline 6 EXP SITC 1: Beverages and tobacco & 0.87 & 0.23 & 0.00 & 0.54 & 0.02 & 0.00 & 0.29 \\
\hline 7 EXP SITC 2: Crude materials, inefible, except fuels & 0.91 & 0.57 & 0.05 & 0.77 & 0.07 & 0.01 & 0.54 \\
\hline 8 EXP SITC 3: Mineral fuels, lubricants and related materials & 0.59 & 0.37 & 0.03 & 0.82 & 0.37 & 0.01 & 0.67 \\
\hline 9 EXP SITC 4: Animal and vegetable oils, fats and waxes & 0.63 & 0.56 & 0.08 & 0.68 & 0.36 & 0.21 & 0.86 \\
\hline 0 EXP SITC 5: Chemicals and related profucts, n.e.s & 0.92 & 0.41 & 0.02 & 0.65 & 0.09 & 0.01 & 0.52 \\
\hline 1 EXP SITC 6: Manufactured goods & 0.92 & 0.42 & 0.02 & 0.69 & 0.03 & 0.01 & 0.38 \\
\hline 2 EXP SITC 7: Machinery and transport equipment & 0.87 & 0.41 & 0.01 & 0.73 & 0.04 & 0.01 & 0.30 \\
\hline 3 EXP SITC 8: Miscellaneous manufactured articles & 0.87 & 0.30 & 0.00 & 0.61 & 0.02 & 0.00 & 0.28 \\
\hline 4 EXP SITC 9: Commodities and transactions n.e.c & 0.24 & 0.03 & 0.01 & 0.70 & 0.58 & 0.03 & 0.78 \\
\hline
\end{tabular}

1/ Forecast horizon is 20 quarters and refers to the levels of the series. Confidence intervals are constructed using bootstrapping methods. 
Table 6. Forecast Error Variance of the Common Components of German Variables Explained by the Supply and Demand Shocks Terms of Trade, 1980-2006 1/

\begin{tabular}{|c|c|c|c|c|c|c|c|}
\hline & \multirow{2}{*}{$\begin{array}{r}\text { Variance Shares } \\
\text { of the Common } \\
\text { Components }\end{array}$} & \multirow{2}{*}{$\begin{array}{l}\text { Supply } \\
\text { Shocks }\end{array}$} & \multicolumn{2}{|c|}{ Confidence Intervals } & \multirow{2}{*}{$\begin{array}{l}\text { Demand } \\
\text { Shock }\end{array}$} & \multicolumn{2}{|c|}{ Confidence Intervals } \\
\hline & & & Lower Bound & Upper Bound & & Lower Bound & Upper Bound \\
\hline 1 GDP & 0.70 & 0.46 & 0.08 & 0.92 & 0.26 & 0.01 & 0.43 \\
\hline 2 Personal consumption expenditure & 0.34 & 0.03 & 0.01 & 0.80 & 0.55 & 0.01 & 0.63 \\
\hline 3 Private investment & 0.93 & 0.09 & 0.04 & 0.88 & 0.73 & 0.02 & 0.73 \\
\hline 4 Employment & 0.77 & 0.27 & 0.06 & 0.88 & 0.53 & 0.01 & 0.63 \\
\hline 5 Productivity & 0.36 & 0.30 & 0.01 & 0.79 & 0.36 & 0.05 & 0.82 \\
\hline 6 Unit labor cost of the manufacturing sector & 0.73 & 0.06 & 0.03 & 0.74 & 0.76 & 0.07 & 0.81 \\
\hline 7 Government savings & 0.70 & 0.09 & 0.02 & 0.86 & 0.55 & 0.01 & 0.60 \\
\hline 8 Consumer confidence & 0.32 & 0.02 & 0.01 & 0.85 & 0.57 & 0.01 & 0.62 \\
\hline 9 Industrial confidence & 0.54 & 0.23 & 0.05 & 0.69 & 0.21 & 0.01 & 0.52 \\
\hline 10 Consumer prices & 0.92 & 0.04 & 0.00 & 0.30 & 0.93 & 0.64 & 0.98 \\
\hline 11 Short-term interest rates & 0.76 & 0.32 & 0.07 & 0.91 & 0.44 & 0.01 & 0.53 \\
\hline 12 Long-term interest rates & 0.54 & 0.16 & 0.07 & 0.78 & 0.14 & 0.02 & 0.61 \\
\hline $13 \mathrm{M} 2$ or M3 & 0.47 & 0.54 & 0.08 & 0.82 & 0.13 & 0.01 & 0.36 \\
\hline 14 Stock prices & 0.69 & 0.07 & 0.02 & 0.84 & 0.58 & 0.01 & 0.63 \\
\hline 15 Real compensation of employees & 0.54 & 0.70 & 0.07 & 0.84 & 0.12 & 0.04 & 0.71 \\
\hline 16 Exports total & 0.69 & 0.54 & 0.12 & 0.91 & 0.33 & 0.01 & 0.48 \\
\hline 17 Imports total & 0.84 & 0.11 & 0.05 & 0.89 & 0.71 & 0.02 & 0.69 \\
\hline 18 Terms of trade & 0.42 & 0.11 & 0.01 & 0.43 & 0.88 & 0.56 & 0.99 \\
\hline 19 Real effective exchange & 0.74 & 0.39 & 0.04 & 0.86 & 0.09 & 0.03 & 0.64 \\
\hline 20 Current account balance & 0.17 & 0.15 & 0.01 & 0.43 & 0.53 & 0.06 & 0.70 \\
\hline 21 FDI out & 0.52 & 0.02 & 0.01 & 0.65 & 0.88 & 0.22 & 0.91 \\
\hline 22 FDI in & 0.15 & 0.07 & 0.01 & 0.88 & 0.45 & 0.00 & 0.51 \\
\hline 23 Exports to Euro & 0.89 & 0.10 & 0.01 & 0.40 & 0.86 & 0.53 & 0.97 \\
\hline 24 Exports to EU & 0.90 & 0.12 & 0.01 & 0.44 & 0.84 & 0.47 & 0.96 \\
\hline 25 Exports to EU accession ctrys & 0.64 & 0.03 & 0.00 & 0.31 & 0.93 & 0.62 & 0.96 \\
\hline 26 Exports to United States & 0.49 & 0.11 & 0.01 & 0.52 & 0.67 & 0.27 & 0.92 \\
\hline 27 Exports to United Kingdom & 0.87 & 0.33 & 0.02 & 0.67 & 0.42 & 0.15 & 0.88 \\
\hline 28 Exports to Japan & 0.81 & 0.42 & 0.02 & 0.69 & 0.44 & 0.20 & 0.88 \\
\hline 29 Exports to China,P.R.: Mainland & 0.69 & 0.26 & 0.09 & 0.85 & 0.01 & 0.01 & 0.42 \\
\hline 30 Exports to Asia & 0.76 & 0.54 & 0.04 & 0.80 & 0.27 & 0.09 & 0.82 \\
\hline 31 Exports to ROW & 0.92 & 0.12 & 0.01 & 0.42 & 0.81 & 0.46 & 0.95 \\
\hline 32 EXP SITC Total & 0.92 & 0.05 & 0.01 & 0.51 & 0.89 & 0.36 & 0.96 \\
\hline 33 EXP SITC 0: Food and live animal & 0.92 & 0.03 & 0.00 & 0.48 & 0.89 & 0.38 & 0.96 \\
\hline 34 EXP SITC 1: Beverages and tobacco & 0.58 & 0.02 & 0.00 & 0.46 & 0.79 & 0.24 & 0.93 \\
\hline 35 EXP SITC 2: Crude materials, inefible, except fuels & 0.81 & 0.05 & 0.02 & 0.65 & 0.89 & 0.23 & 0.94 \\
\hline 36 EXP SITC 3: Mineral fuels, lubricants and related materials & 0.64 & 0.25 & 0.05 & 0.80 & 0.69 & 0.05 & 0.78 \\
\hline 37 EXP SITC 4: Animal and vegetable oils, fats and waxes & 0.41 & 0.20 & 0.04 & 0.77 & 0.08 & 0.00 & 0.31 \\
\hline 38 EXP SITC 5: Chemicals and related profucts, n.e.s & 0.89 & 0.04 & 0.01 & 0.56 & 0.89 & 0.26 & 0.96 \\
\hline 39 EXP SITC 6: Manufactured goods & 0.91 & 0.05 & 0.01 & 0.55 & 0.88 & 0.31 & 0.96 \\
\hline 40 EXP SITC 7: Machinery and transport equipment & 0.89 & 0.05 & 0.01 & 0.49 & 0.87 & 0.39 & 0.96 \\
\hline 41 EXP SITC 8: Miscellaneous manufactured articles & 0.92 & 0.04 & 0.00 & 0.47 & 0.89 & 0.38 & 0.96 \\
\hline 42 EXP SITC 9: Commodities and transactions n.e.c & 0.08 & 0.19 & 0.01 & 0.62 & 0.79 & 0.33 & 0.95 \\
\hline
\end{tabular}

1/ Forecast horizon is 20 quarters and refers to the levels of the series. Confidence intervals are constructed using bootstrapping methods. 
Table 7. Forecast Error Variance of the Common Components of France Variables Explained by the Supply and Demand Shock to ULCM, 1993-2006 1/

\begin{tabular}{|c|c|c|c|c|c|c|c|}
\hline & \multirow{2}{*}{$\begin{array}{r}\text { Variance Shares } \\
\text { of the Common } \\
\text { Components }\end{array}$} & \multirow{2}{*}{$\begin{array}{l}\text { Supply } \\
\text { Shocks }\end{array}$} & \multicolumn{2}{|c|}{ Confidence Intervals } & \multirow{2}{*}{$\begin{array}{r}\text { Demand } \\
\text { Shock }\end{array}$} & \multicolumn{2}{|c|}{ Confidence Intervals } \\
\hline & & & Lower Bound & Upper Bound & & Lower Bound & Upper Bound \\
\hline 1 GDP & 0.88 & 0.32 & 0.01 & 0.92 & 0.59 & 0.03 & 0.95 \\
\hline 2 Personal consumption expenditure & 0.59 & 0.28 & 0.01 & 0.92 & 0.64 & 0.04 & 0.96 \\
\hline 3 Private investment & 0.89 & 0.26 & 0.01 & 0.94 & 0.66 & 0.02 & 0.97 \\
\hline 4 Employment & 0.84 & 0.27 & 0.03 & 0.87 & 0.62 & 0.03 & 0.90 \\
\hline 5 Productivity & 0.72 & 0.78 & 0.01 & 0.74 & 0.10 & 0.04 & 0.89 \\
\hline 6 Unit labor cost of the manufacturing sector & 0.73 & 0.13 & 0.00 & 0.95 & 0.79 & 0.02 & 0.98 \\
\hline 7 Government savings & 0.89 & 0.31 & 0.01 & 0.93 & 0.59 & 0.02 & 0.96 \\
\hline 8 Consumer confidence & 0.71 & 0.59 & 0.01 & 0.80 & 0.28 & 0.06 & 0.93 \\
\hline 9 Industrial confidence & 0.60 & 0.29 & 0.01 & 0.67 & 0.43 & 0.08 & 0.89 \\
\hline 10 Consumer prices & 0.86 & 0.19 & 0.01 & 0.93 & 0.68 & 0.02 & 0.97 \\
\hline 11 Short-term interest rates & 0.67 & 0.31 & 0.04 & 0.86 & 0.49 & 0.04 & 0.86 \\
\hline 12 Long-term interest rates & 0.71 & 0.38 & 0.02 & 0.63 & 0.45 & 0.01 & 0.63 \\
\hline $13 \mathrm{M} 2$ or M3 & 0.39 & 0.49 & 0.02 & 0.72 & 0.29 & 0.02 & 0.63 \\
\hline 14 Stock prices & 0.94 & 0.61 & 0.01 & 0.82 & 0.21 & 0.02 & 0.86 \\
\hline 15 Real compensation of employees & 0.79 & 0.32 & 0.05 & 0.86 & 0.47 & 0.04 & 0.84 \\
\hline 16 SMIC & 0.71 & 0.08 & 0.00 & 0.95 & 0.81 & 0.02 & 0.98 \\
\hline 17 TFP & 0.86 & 0.12 & 0.01 & 0.95 & 0.83 & 0.03 & 0.97 \\
\hline 18 Exports total & 0.70 & 0.30 & 0.03 & 0.88 & 0.58 & 0.03 & 0.91 \\
\hline 19 Imports total & 0.90 & 0.23 & 0.01 & 0.94 & 0.71 & 0.04 & 0.97 \\
\hline 20 Terms of trade & 0.10 & 0.23 & 0.01 & 0.83 & 0.42 & 0.04 & 0.82 \\
\hline 21 Real effective exchange & 0.80 & 0.37 & 0.02 & 0.65 & 0.01 & 0.05 & 0.70 \\
\hline 22 Current account balance & 0.86 & 0.28 & 0.03 & 0.76 & 0.57 & 0.04 & 0.84 \\
\hline 23 FDI out & 0.91 & 0.61 & 0.01 & 0.79 & 0.23 & 0.03 & 0.89 \\
\hline 24 FDI in & 0.67 & 0.33 & 0.03 & 0.87 & 0.48 & 0.04 & 0.87 \\
\hline 25 Exports to Euro & 0.86 & 0.10 & 0.01 & 0.68 & 0.42 & 0.08 & 0.87 \\
\hline 26 Exports to EU & 0.88 & 0.10 & 0.01 & 0.68 & 0.41 & 0.08 & 0.87 \\
\hline 27 Exports to EU accession ctrys & 0.78 & 0.02 & 0.00 & 0.88 & 0.71 & 0.04 & 0.94 \\
\hline 28 Exports to United States & 0.86 & 0.77 & 0.02 & 0.64 & 0.06 & 0.05 & 0.82 \\
\hline 29 Exports to United Kingdom & 0.87 & 0.21 & 0.01 & 0.69 & 0.20 & 0.08 & 0.86 \\
\hline 30 Exports to Japan & 0.86 & 0.29 & 0.01 & 0.56 & 0.28 & 0.03 & 0.69 \\
\hline 31 Exports to China,P.R.: Mainland & 0.57 & 0.29 & 0.01 & 0.68 & 0.08 & 0.06 & 0.82 \\
\hline 32 Exports to Asia & 0.70 & 0.23 & 0.01 & 0.62 & 0.48 & 0.03 & 0.79 \\
\hline 33 Exports to ROW & 0.70 & 0.27 & 0.01 & 0.72 & 0.16 & 0.08 & 0.87 \\
\hline 34 EXP SITC Total & 0.93 & 0.04 & 0.01 & 0.68 & 0.93 & 0.08 & 0.89 \\
\hline 35 EXP SITC 0: Food and live animal & 0.67 & 0.32 & 0.01 & 0.72 & 0.51 & 0.07 & 0.79 \\
\hline 36 EXP SITC 1: Beverages and tobacco & 0.91 & 0.08 & 0.01 & 0.71 & 0.86 & 0.09 & 0.87 \\
\hline 37 EXP SITC 2: Crude materials, inefible, except fuels & 0.93 & 0.07 & 0.01 & 0.66 & 0.90 & 0.05 & 0.87 \\
\hline 38 EXP SITC 3: Mineral fuels, lubricants and related materials & 0.74 & 0.05 & 0.01 & 0.86 & 0.93 & 0.09 & 0.95 \\
\hline 39 EXP SITC 4: Animal and vegetable oils, fats and waxes & 0.79 & 0.52 & 0.01 & 0.72 & 0.38 & 0.04 & 0.72 \\
\hline 40 EXP SITC 5: Chemicals and related profucts, n.e.s & 0.94 & 0.15 & 0.00 & 0.70 & 0.82 & 0.06 & 0.83 \\
\hline 41 EXP SITC 6: Manufactured goods & 0.94 & 0.07 & 0.01 & 0.68 & 0.90 & 0.07 & 0.88 \\
\hline 42 EXP SITC 7: Machinery and transport equipment & 0.90 & 0.02 & 0.00 & 0.70 & 0.97 & 0.07 & 0.93 \\
\hline 43 EXP SITC 8: Miscellaneous manufactured articles & 0.91 & 0.06 & 0.01 & 0.68 & 0.91 & 0.10 & 0.88 \\
\hline 44 EXP SITC 9: Commodities and transactions n.e.c & 0.57 & 0.52 & 0.01 & 0.74 & 0.40 & 0.04 & 0.74 \\
\hline
\end{tabular}


Table 8. Forecast Error Variance of the Common Components of Germany Variables Explained by the Supply and Demand Shock to ULCM, 1993-2006 1/

\begin{tabular}{|c|c|c|c|c|c|c|c|}
\hline & \multirow{2}{*}{$\begin{array}{r}\text { Variance Shares } \\
\text { of the Common } \\
\text { Components }\end{array}$} & \multirow{2}{*}{$\begin{array}{l}\text { Supply } \\
\text { Shocks }\end{array}$} & \multicolumn{2}{|c|}{ Confidence Intervals } & \multirow{2}{*}{$\begin{array}{r}\text { Demand } \\
\text { Shock }\end{array}$} & \multicolumn{2}{|c|}{ Confidence Intervals } \\
\hline & & & Lower Bound & Upper Bound & & Lower Bound & Upper Bound \\
\hline 1 GDP & 0.90 & 0.14 & 0.02 & 0.59 & 0.43 & 0.29 & 0.91 \\
\hline 2 Personal consumption expenditure & 0.77 & 0.25 & 0.01 & 0.56 & 0.30 & 0.12 & 0.81 \\
\hline 3 Private investment & 0.95 & 0.05 & 0.01 & 0.45 & 0.79 & 0.49 & 0.96 \\
\hline 4 Employment & 0.90 & 0.06 & 0.02 & 0.55 & 0.59 & 0.36 & 0.93 \\
\hline 5 Productivity & 0.34 & 0.33 & 0.02 & 0.80 & 0.38 & 0.01 & 0.45 \\
\hline 6 Unit labor cost of the manufacturing sector & 0.81 & 0.05 & 0.00 & 0.35 & 0.93 & 0.58 & 0.99 \\
\hline 7 Government savings & 0.88 & 0.01 & 0.01 & 0.51 & 0.67 & 0.27 & 0.91 \\
\hline 8 Consumer confidence & 0.59 & 0.04 & 0.00 & 0.33 & 0.87 & 0.50 & 0.94 \\
\hline 9 Industrial confidence & 0.65 & 0.11 & 0.01 & 0.49 & 0.73 & 0.21 & 0.92 \\
\hline 10 Consumer prices & 0.94 & 0.09 & 0.00 & 0.42 & 0.85 & 0.46 & 0.97 \\
\hline 11 Short-term interest rates & 0.91 & 0.03 & 0.02 & 0.62 & 0.52 & 0.26 & 0.92 \\
\hline 12 Long-term interest rates & 0.69 & 0.85 & 0.01 & 0.75 & 0.03 & 0.01 & 0.57 \\
\hline $13 \mathrm{M} 2$ or $\mathrm{M} 3$ & 0.72 & 0.26 & 0.01 & 0.63 & 0.28 & 0.06 & 0.67 \\
\hline 14 Stock prices & 0.86 & 0.01 & 0.01 & 0.48 & 0.78 & 0.37 & 0.94 \\
\hline 15 Real compensation of employees & 0.51 & 0.07 & 0.02 & 0.73 & 0.33 & 0.07 & 0.61 \\
\hline 16 Exports total & 0.80 & 0.17 & 0.01 & 0.52 & 0.58 & 0.38 & 0.94 \\
\hline 17 Imports total & 0.92 & 0.06 & 0.01 & 0.42 & 0.82 & 0.53 & 0.97 \\
\hline 18 Terms of trade & 0.39 & 0.29 & 0.00 & 0.54 & 0.69 & 0.30 & 0.94 \\
\hline 19 Real effective exchange & 0.64 & 0.01 & 0.02 & 0.71 & 0.26 & 0.10 & 0.79 \\
\hline 20 Current account balance & 0.60 & 0.05 & 0.01 & 0.57 & 0.42 & 0.07 & 0.81 \\
\hline 21 FDI out & 0.61 & 0.01 & 0.00 & 0.41 & 0.93 & 0.42 & 0.95 \\
\hline 22 FDI in & 0.20 & 0.03 & 0.01 & 0.51 & 0.69 & 0.18 & 0.88 \\
\hline 23 Exports to Euro & 0.91 & 0.12 & 0.01 & 0.61 & 0.64 & 0.20 & 0.90 \\
\hline 24 Exports to EU & 0.92 & 0.12 & 0.01 & 0.63 & 0.60 & 0.18 & 0.88 \\
\hline 25 Exports to EU accession ctrys & 0.76 & 0.12 & 0.00 & 0.56 & 0.72 & 0.28 & 0.92 \\
\hline 26 Exports to United States & 0.74 & 0.01 & 0.03 & 0.76 & 0.24 & 0.08 & 0.52 \\
\hline 27 Exports to United Kingdom & 0.91 & 0.09 & 0.02 & 0.72 & 0.34 & 0.09 & 0.68 \\
\hline 28 Exports to Japan & 0.89 & 0.19 & 0.02 & 0.72 & 0.24 & 0.07 & 0.59 \\
\hline 29 Exports to China,P.R.: Mainland & 0.67 & 0.06 & 0.01 & 0.47 & 0.76 & 0.39 & 0.96 \\
\hline 30 Exports to Asia & 0.95 & 0.32 & 0.02 & 0.70 & 0.05 & 0.07 & 0.50 \\
\hline 31 Exports to ROW & 0.94 & 0.16 & 0.00 & 0.63 & 0.59 & 0.19 & 0.88 \\
\hline 32 EXP SITC Total & 0.95 & 0.10 & 0.01 & 0.67 & 0.45 & 0.13 & 0.87 \\
\hline 33 EXP SITC 0: Food and live animal & 0.95 & 0.05 & 0.01 & 0.70 & 0.49 & 0.13 & 0.87 \\
\hline 34 EXP SITC 1: Beverages and tobacco & 0.67 & 0.26 & 0.02 & 0.78 & 0.25 & 0.07 & 0.62 \\
\hline 35 EXP SITC 2: Crude materials, inefible, except fuels & 0.85 & 0.11 & 0.01 & 0.64 & 0.49 & 0.16 & 0.89 \\
\hline 36 EXP SITC 3: Mineral fuels, lubricants and related materials & 0.59 & 0.01 & 0.00 & 0.38 & 0.83 & 0.48 & 0.97 \\
\hline 37 EXP SITC 4: Animal and vegetable oils, fats and waxes & 0.67 & 0.13 & 0.05 & 0.79 & 0.18 & 0.04 & 0.49 \\
\hline 38 EXP SITC 5: Chemicals and related profucts, n.e.s & 0.94 & 0.14 & 0.01 & 0.70 & 0.41 & 0.12 & 0.83 \\
\hline 39 EXP SITC 6: Manufactured goods & 0.92 & 0.10 & 0.01 & 0.68 & 0.45 & 0.13 & 0.86 \\
\hline 40 EXP SITC 7: Machinery and transport equipment & 0.92 & 0.09 & 0.01 & 0.69 & 0.46 & 0.14 & 0.86 \\
\hline 41 EXP SITC 8: Miscellaneous manufactured articles & 0.94 & 0.07 & 0.01 & 0.71 & 0.47 & 0.13 & 0.86 \\
\hline 42 EXP SITC 9: Commodities and transactions n.e.c & 0.61 & 0.43 & 0.01 & 0.72 & 0.07 & 0.01 & 0.41 \\
\hline
\end{tabular}

1/ Forecast horizon is 20 quarters and refers to the levels of the series. Confidence intervals are constructed using bootstrapping methods. 


\section{Appendix I. The Corbae-Ouliaris Ideal Band-Pass Filter}

Let us assume that $X_{t}$ is an I(1) process with $\Delta X_{t}=v_{t}$ such that $v_{t}$ has a Wold representation. The spectral density of $v_{t}$ is $f_{v v}(\lambda)>0$, for all $\lambda$. The discrete Fourier transform of $X_{t}$ for $\lambda_{t} \neq 0$ :

$w_{X}\left(\lambda_{s}\right)=\frac{1}{1-e^{i \lambda_{s}}} w_{v}\left(\lambda_{s}\right)-\frac{e^{i \lambda_{s}}}{1-e^{i \lambda_{s}}} \frac{\left(X_{n}-X_{0}\right)}{n^{1 / 2}}$

where $\lambda_{s}=\frac{2 \pi s}{n}, \mathrm{~s}=0,1, \ldots, \mathrm{n}-1$, are the fundamental frequencies. The second term makes it clear that the Fourier transform is not asymptotically independent across fundamental frequencies because the second term is a deterministic trend in the frequency domain with a random coefficient $\frac{\left(X_{n}-X_{0}\right)}{n^{1 / 2}}$. Unless that term is removed, it will produce leakages into all frequencies $\lambda_{t} \neq 0$, even in the limit as $n \rightarrow \infty$. Sacrificing a single observation, instead of estimating the random coefficient a la Hannan (1970), Corbae and Ouliaris (2006) show that by imposing that $\left(X_{n}-X_{1}\right)=\left(X_{n}-X_{0}\right)$ will produce an estimate that will have no finite sampling error, has superior endpoint properties, and has much lower mean-squared error than popular time-domain filters such as HP or B-K. In addition, in contrast to B-K, it is consistent. This is the ideal band-pass filter used in the paper. 


\section{Appendix II. The Approximate Dynamic Factor Model}

This study uses a large dimensional approximate dynamic factor model in the tradition of Stock and Watson (1998 and 2002). In contrast to the models of Sargent and Sims (1977) and Geweke (1977), it admits the possibility of serial correlation and weakly cross-sectional correlation of idiosyncratic components, as in Chamberlain (1983) and Chamberlain and Rothschild (1983). Similar models have recently been used by Giannone, Reichlin, and Sala (2002), Forni and others (2005), and Eickmeier (2006 and 2007).

A vector of time series $Y_{t}=\left(y_{1 t}, y_{2 t}, \ldots, y_{N t}\right)^{\prime}$ can be represented as the sum of two latent components, a common component $X_{t}=\left(x_{1 t}, x_{2 t}, \ldots, x_{N t}\right)^{\prime}$ and an idiosyncratic component $\Xi_{t}=\left(\varepsilon_{1 t}, \varepsilon_{2 t}, \ldots, \varepsilon_{N t}\right)^{\prime}$

$Y_{t}=X_{t}+\Xi_{t}$

$Y_{t}=C F_{t}+\Xi_{t}$

where $F_{t}=\left(f_{1 t}, f_{2 t}, \ldots, f_{r t}\right)^{\prime}$ is a vector of $r$ common factors, and $C=\left(c_{1}^{\prime}, c_{2}^{\prime}, \ldots, c_{N}^{\prime}\right)^{\prime}$ is a $N \times r$ matrix of factor loadings, with $r<<N$. The common component $X_{t}$, which is a linear combination of common factors, is driven by few common shocks, which are the same for all variables. Nevertheless, the effects of common shocks differ from one variable to another due to different factor loadings. The idiosyncratic component is driven by idiosyncratic shocks, specific to each variable. The static factor model used here differs from the dynamic factor model in that it treats lagged or dynamic factors $F_{t}$ as additional static factors. Thus, common factors include both lagged and contemporaneous factors.

Using the law of large number (as $T, N \rightarrow \infty$ ), the idiosyncratic component, which is weakly correlated by construction, vanishes; and therefore, the common component can be easily estimated in a consistent manner by using standard principal component analysis. The first $r$ eigenvalues and eigenvectors are calculated from the variance-covariance matrix $\operatorname{cov}\left(Y_{t}\right)$.

$X_{t}=V V^{\prime} Y_{t}$

and since the factor loadings $C=V$, equation (1) becomes,

$$
F_{t}=V^{\prime} Y_{t}
$$

From (1), the idiosyncratic component is

$$
\Xi_{t}=Y_{t}-X_{t}
$$


From all the more or less formal criteria to determine the number of static factors $r$, Bai and $\mathrm{Ng}$ (2002) information criteria was followed. As in Forni and others (2005), $F_{t}$ was approximated by an autoregressive representation of order $1^{11}$ :

$$
F_{t}=B F_{t-1}+u_{t},
$$

where $B$ is a $r \times r$ matrix and $u_{t}$ a $r \times t$ vector of residuals. Equation (5) is the reduced form model of (1).

Once a decision is taken on the process followed by the common components, structural shocks have to be identified by focusing on the reduced form VAR residuals of (5). Following Eickmeier (2007), the identification scheme has three steps. First, maximize the variance of the forecast error of the chosen variable and calculate impulse-response functions. The interest here is unit labor costs in manufacturing (ULCM) and terms of trade. So, using ULCM as an example, a few major shocks driving unit them are identified. ${ }^{12}$ This implies maximizing the explanation of the chosen variance of the $k$-step ahead forecast error of ULCM with a reduced number of shocks. ${ }^{13}$ To this end, $k$-ahead prediction errors $u_{t}$ are decomposed into $k$ mutually orthogonal innovations using the Cholesky decomposition. The lower triangular Cholesky matrix $A$ is such that $u_{t}=A v_{t}$ and $E\left(v_{t} v_{t}^{\prime}\right)=I$. Hence,

$\operatorname{cov}\left(u_{t}\right)=A E\left(v_{t} v_{t}^{\prime}\right) A^{\prime}=A A^{\prime}$

The impulse-response function of $y_{i t}$ to the identified shock in period $k$ is obtained as follows:

$R_{i k}=c_{i} B^{k} A$

\footnotetext{
${ }^{11} \mathrm{VAR}(1)$ provides a dynamic representation which is parsimonious and quite general (for more details, see Gianonne, 2005). The residuals $u_{t}$ were white noise and thus an autoregressive process of order 1 was chosen.

${ }^{12}$ Uhlig (2003) shows that two shocks are sufficient to explain 90 percent of the variance at all horizons of real U.S. GNP.

${ }^{13}$ If, for example, two orthogonal shocks are identified, it is incorrect to identify the first shock as the one corresponding to the first eigenvalue and the second orthogonal shock as the one corresponding to the second eigenvalue (see Uhlig, 2003). The two orthogonal shocks identified generate together the total variation which explanation is being maximized. However, there are multiple possible combinations of those orthogonal shocks all of which will still explain the total variation chosen: as an illustration, and measuring angles in degrees, the pairings of orthogonal shocks with rotation angles $\{0,90\}$ or $\{30,120\}$ or $\{60,150\}$ would be equally acceptable. The grid of the angle of rotation can be different, of course. This paper uses a grid of 30 degrees.
} 
with $c_{\mathrm{i}}$ the $i$ th row of factor loadings of $C$ and with a corresponding variance-covariance matrix $\sum_{j=0}^{k} R_{i j} R_{i j}^{\prime}$.

Second, the identified shocks are assumed to be linearly correlated to a vector of fundamentals. The fundamental forces $\omega_{t}=\left(\omega_{1 t}, \omega_{2 t}, \ldots, \omega_{r t}\right)^{\prime}$ behind France's ULCM are correlated to the identified shocks through the $r \times r$ matrix $Q$. Thus,

$v_{t}=Q \omega_{t}$.

The intuition of the procedure is to select $Q$ in such a way that the first shock explains as much as possible of the forecast error variance of the France's ULCM common component over a certain horizon $k$, and the second shock explains as much as possible of the remaining forecast error variance. Focusing on the first shock, the task is to explain as much as possible of its error variance

$\sigma^{2}(k)=\sum_{j=0}^{k}\left(R_{i j} q_{1}\right)\left(R_{i j} q_{1}\right)^{\prime}$,

where $i$ is, in our example, the French ULCM, and $q_{1}$ is the first column of $Q$. The column $q_{1}$ is selected in such a way that $q_{1}^{\prime} \sigma^{2} q_{1}$ is maximized, that is

$$
\begin{aligned}
\sigma^{2}(k) & =\sum_{j=0}^{k}\left(R_{i j} q_{1}\right)\left(R_{i j} q_{1}\right)^{\prime} \\
& =q_{1}^{\prime} S_{i k} q_{1}
\end{aligned}
$$

where $S_{i k}=\sum_{j=0}^{k}(k+1-j) R_{i j}^{\prime} R_{i j}$.

The maximization problem subject to the side constraint $q_{1}^{\prime} q_{1}=1$, can be written as the Lagrangean,

$L=q_{1}^{\prime} S_{i k} q_{1}-\lambda\left(q_{1}^{\prime} q_{1}-1\right)$,

where $\lambda$ is the Lagrangean multiplier. From (10), $q_{1}$ is the first eigenvector of $S_{i k}$ with eigenvalue $\lambda$ and, therefore, the shock associated with $q_{1}$ is the first principal component shock. $Q$ is the matrix of eigenvectors of $S,\left(q_{1}, q_{2}, \ldots, q_{r}\right)$, where $q_{l}(l=1, \ldots, r)$ is the eigenvector corresponding to the $l^{\text {th }}$ principal component shock. Along the lines of Uhlig (2003), Eickmeier (2007), and Altig and others (2002), it is posed: $k=0$ to $k=19$, i.e., five years, which covers short- as well as medium-run dynamics. 
Finally, orthogonal shocks are identified by rotation. If two shocks are identified, following Canova and de Nicoló (2003), the orthogonal shocks vector $\omega_{t}=\left(\omega_{1 t}, \omega_{2 t}\right)^{\prime}$ is multiplied by a $2 \times 2$ orthogonal rotation matrix $P$ of the form:

$P=\left(\begin{array}{lr}\cos (\theta) & -\sin (\theta) \\ \sin (\theta) & \cos (\theta)\end{array}\right)$,

where $\theta$ is the rotation angle; $\theta \in(0, \pi)$, produces all possible rotations and varies on a grid. If $\theta$ is fixed, and $q=5$, there are $q(q-1) / 2$ bivariate rotations of different elements of the VAR. Following the insights of Sims and Zha (1999), and as in Peersman (2005), Canova and de Nicoló (2003), Eickmeier (2007), Kabundi and Nadal De Simone (2007) the number of angles between 0 and $\pi$ is assumed to be 12 : this implies $6,191,736,421 \times 10^{10}\left(12^{10}\right)$ rotations. Hence, the rotated factor $w_{t}=P w_{t}$ explains in total all the variation measured by the first two eigenvalues. This way the two principal components $\omega_{i}$ are associated to the two structural shocks $w_{i}$ through the matrix $P$, and the impulse-response functions of the two structural shocks on all the fundamental forces can be estimated.

A sign-identification strategy is followed to identify the shocks. The method was developed by Peersman (2005). This strategy imposes inequality sign restrictions on the impulse response functions of variables based on a typical aggregate demand and aggregate supply framework. ${ }^{14}$ Only those rotations among all possible $q \times q$ rotations that have a structural meaning are chosen. The text table displays the sign restrictions for the identification of shocks that are imposed contemporaneously and during the first year after the shock.

\section{Identification Inequalities}

\begin{tabular}{lcc}
\hline & \multicolumn{2}{c}{ Increase in ULCM } \\
\cline { 2 - 3 } & Supply shock & Demand shock \\
\hline ULCM & $\leq 0$ & $\geq 0$ \\
Output & $\leq 0$ & $\geq 0$ \\
Real wages & \multicolumn{2}{c}{ Increase in Terms of Trade } \\
\hline \multirow{2}{*}{ Terms of trade } & $\geq 0$ & $\geq 0$ \\
Consumption & $\geq 0$ & $\leq 0$ \\
Current account & $\leq 0$ & $\geq 0$ \\
\hline
\end{tabular}

${ }^{14}$ See Peersman (2005) for more technical details. 
Annex I. Macroeconomic Series

\begin{tabular}{|c|c|c|}
\hline Series No. & Country/Region & Variable Name \\
\hline 1 & World & $\begin{array}{l}\text { Commodity Industrial Inputs Price Index, } 1995=100 \text {, includes } \\
\text { Agricultural Raw Materials and Metals Price Indices }\end{array}$ \\
\hline 2 & World & $\begin{array}{l}\text { Crude Oil (petroleum), simple average of three spot prices; Dated Brent, } \\
\text { West Texas Intermediate, and the Dubai Fateh, US\$ per barrel }\end{array}$ \\
\hline 3 & World & Exchange rate, U.S. dollars per national currency, period average \\
\hline 4 & World & Fed Funds \\
\hline 5 & World & S\&P 500 \\
\hline 6 & World & World demand \\
\hline 7 & World & World reserves \\
\hline 8 & France & PPI \\
\hline 9 & France & Real Effective exchange rate, $2000=100$, ULC-based \\
\hline 10 & France & Gross domestic product deflator \\
\hline 11 & France & $\mathrm{CPI}$ \\
\hline 12 & France & Import Unit Values / Import Prices \\
\hline 13 & France & Export Unit Values / Export Prices \\
\hline 14 & France & Private final consumption expenditure, volume \\
\hline 15 & France & Dependent employment \\
\hline 16 & France & Dependent employment of the business sector \\
\hline 17 & France & Government employment \\
\hline 18 & France & Self-employed \\
\hline 19 & France & Total employment \\
\hline 20 & France & Employment of the business sector \\
\hline 21 & France & Exchange rate, index of US\$ per local currency \\
\hline 22 & France & Gross domestic product, constant prices \\
\hline 23 & France & Private non-residential fixed capital formation, volume \\
\hline 24 & France & Fixed investment in non-residential construction, volume \\
\hline 25 & France & Fixed investment in construction, volume \\
\hline 26 & France & Government fixed capital formation, volume \\
\hline 27 & France & Private residential fixed capital formation, volume \\
\hline 28 & France & Fixed investment in machinery \& equipment, volume \\
\hline 29 & France & Industrial production \\
\hline 30 & France & Private total fixed capital formation, volume \\
\hline 31 & France & Gross total fixed capital formation, volume \\
\hline 32 & France & Labor force \\
\hline 33 & France & Imports of goods and services, volume, national accounts basis \\
\hline 34 & France & Labor productivity of the total economy \\
\hline 35 & France & Household saving, value \\
\hline 36 & France & Current transfers received by households, value \\
\hline 37 & France & Unit labor cost of the total economy \\
\hline 38 & France & Unit labor cost of the manufacturing sector \\
\hline 39 & France & Unemployment \\
\hline 40 & France & Wages, value \\
\hline 41 & France & Wages of the government sector, value \\
\hline 42 & France & Wage rate of the business sector \\
\hline 43 & France & Compensation rate of government employees \\
\hline 44 & France & Wage rate of the manufacturing sector, hourly earnings \\
\hline 45 & France & Compensation rate of the business sector \\
\hline 46 & France & Compensation of employees, value \\
\hline
\end{tabular}


Annex I. Macroeconomic Series

\begin{tabular}{|c|c|c|}
\hline Series No. & Country/Region & Variable Name \\
\hline 47 & France & Exports of goods and services, volume, national accounts basis \\
\hline 48 & France & Household disposable income, real \\
\hline 49 & France & Property income received by households, value \\
\hline 50 & France & Government current disbursements, value \\
\hline 51 & France & Current disbursements of households, value \\
\hline 52 & France & Government current receipts, value \\
\hline 53 & France & Current receipts of households, value \\
\hline 54 & France & Self-employment income received by households, value \\
\hline 55 & France & Money supply, broad definition M2 or M3 \\
\hline 56 & France & Credit to private sector \\
\hline 57 & France & $\mathrm{HPI}$ \\
\hline 58 & France & SPI \\
\hline 59 & France & TFP growth \\
\hline 60 & France & Direct investment abroad \\
\hline 61 & France & Dir. invest. in rep. econ., n.i.e. \\
\hline 62 & France & Portfolio investment assets \\
\hline 63 & France & Portfolio investment liab., n.i.e \\
\hline 64 & France & Other investment assets \\
\hline 65 & France & Other investment liab., n.i.e \\
\hline 66 & France & Financial account, n.i.e. \\
\hline 67 & France & Capacity utilization \\
\hline 68 & France & Balance of income, value, balance of payments basis \\
\hline 69 & France & Current account, value \\
\hline 70 & France & Current account, value in US\$ \\
\hline 71 & France & Government consumption of fixed capital, value \\
\hline 72 & France & Long-term interest rate on government bonds \\
\hline 73 & France & Short-term interest rate $\backslash$ PERCENT \\
\hline 74 & France & Increase in stocks, volume \\
\hline 75 & France & Labor force participation rate \\
\hline 76 & France & Government saving(net), value \\
\hline 77 & France & Household saving ratio \\
\hline 78 & France & Unemployment rate \\
\hline 79 & France & Industrial confidence \\
\hline 80 & France & Consumer confidence \\
\hline 81 & France & Smic \\
\hline 82 & France & Terms of trade \\
\hline 83 & France & Real compensation of employees \\
\hline 84 & Germany & PPI \\
\hline 85 & Germany & Real Effective exchange rate, $2000=100$, ULC-based \\
\hline 86 & Germany & Gross domestic product, deflator, market prices \\
\hline 87 & Germany & Q2-2007 \\
\hline 88 & Germany & Import Unit Values / Import Prices \\
\hline 89 & Germany & Export Unit Values / Export Prices \\
\hline 90 & Germany & Government consumption of fixed capital, value \\
\hline 91 & Germany & Private final consumption expenditure, volume \\
\hline 92 & Germany & Dependent employment \\
\hline 93 & Germany & Self-employed \\
\hline 94 & Germany & Total employment \\
\hline
\end{tabular}


Annex I. Macroeconomic Series

\begin{tabular}{|c|c|c|}
\hline Series No. & Country/Region & Variable Name \\
\hline 95 & Germany & Exchange rate, index of US\$ per local currency \\
\hline 96 & Germany & Gross domestic product, volume, market prices \\
\hline 97 & Germany & Private non-residential fixed capital formation, volume \\
\hline 98 & Germany & Fixed investment in non-residential construction, volume \\
\hline 99 & Germany & Fixed investment in construction, volume \\
\hline 100 & Germany & Government fixed capital formation, volume \\
\hline 101 & Germany & Private residential fixed capital formation, volume \\
\hline 102 & Germany & Fixed investment in machinery \& equipment, volume \\
\hline 103 & Germany & Industrial production \\
\hline 104 & Germany & Private total fixed capital formation, volume \\
\hline 105 & Germany & Gross total fixed capital formation, volume \\
\hline 106 & Germany & Labor force \\
\hline 107 & Germany & Imports of goods and services, volume, national accounts basis \\
\hline 108 & Germany & Labor productivity of the total economy \\
\hline 109 & Germany & Household saving, value \\
\hline 110 & Germany & Current transfers received by households, value \\
\hline 111 & Germany & Unit labor cost of the total economy \\
\hline 112 & Germany & Unit labor cost of the manufacturing sector \\
\hline 113 & Germany & Unemployment \\
\hline 114 & Germany & Wages, value \\
\hline 115 & Germany & Wages of the government sector, value \\
\hline 116 & Germany & Compensation of employees, value \\
\hline 117 & Germany & Exports of goods and services, volume, national accounts basis \\
\hline 118 & Germany & Factor income from abroad, volume, balance of payments basis \\
\hline 119 & Germany & Household disposable income, real \\
\hline 120 & Germany & Government current disbursements, value \\
\hline 121 & Germany & Current disbursements of households, value \\
\hline 122 & Germany & Government current receipts, value \\
\hline 123 & Germany & Current receipts of households, value \\
\hline 124 & Germany & Money supply, broad definition M2 or M3 \\
\hline 125 & Germany & Claims on oth resid sector \\
\hline 126 & Germany & $\mathrm{HPI}$ \\
\hline 127 & Germany & SPI \\
\hline 128 & Germany & Direct investment abroad \\
\hline 129 & Germany & Dir. invest. in rep. econ., n.i.e. \\
\hline 130 & Germany & Portfolio investment assets \\
\hline 131 & Germany & Portfolio investment liab., n.i.e \\
\hline 132 & Germany & Other investment assets \\
\hline 133 & Germany & Other investment liab., n.i.e \\
\hline 134 & Germany & Financial account, n.i.e. \\
\hline 135 & Germany & Capacity utilization \\
\hline 136 & Germany & Balance of income, value, balance of payments basis \\
\hline 137 & Germany & Current account, value \\
\hline 138 & Germany & Current account, value in US\$ \\
\hline 139 & Germany & Long-term interest rate on government bonds \\
\hline 140 & Germany & Short-term interest rate \\
\hline 141 & Germany & Labor force participation rate \\
\hline 142 & Germany & Government saving(net), value \\
\hline
\end{tabular}


Annex I. Macroeconomic Series

\begin{tabular}{|c|c|c|}
\hline Series No. & Country/Region & Variable Name \\
\hline 143 & Germany & Household saving ratio \\
\hline 144 & Germany & Unemployment rate \\
\hline 145 & Germany & Industrial confidence \\
\hline 146 & Germany & Consumer confidence \\
\hline 147 & Germany & Terms of trade \\
\hline 148 & Germany & Stock prices \\
\hline 149 & Germany & Real compensation of employees \\
\hline 150 & Japan & PPI \\
\hline 151 & Japan & Real Effective exchange rate, $2000=100$, ULC-based \\
\hline 152 & Japan & Gross domestic product deflator \\
\hline 153 & Japan & $\mathrm{CPI}$ \\
\hline 154 & Japan & Import Unit Values / Import Prices \\
\hline 155 & Japan & Export Unit Values / Export Prices \\
\hline 156 & Japan & Private final consumption expenditure, volume \\
\hline 157 & Japan & Dependent employment \\
\hline 158 & Japan & Dependent employment of the business sector \\
\hline 159 & Japan & Government employment \\
\hline 160 & Japan & Self-employed \\
\hline 161 & Japan & Total employment \\
\hline 162 & Japan & Employment of the business sector \\
\hline 163 & Japan & Exchange rate, index of US\$ per local currency \\
\hline 164 & Japan & Gross domestic product, volume, market prices \\
\hline 165 & Japan & Private non-residential fixed capital formation, volume \\
\hline 166 & Japan & Government fixed capital formation, volume \\
\hline 167 & Japan & Private residential fixed capital formation, volume \\
\hline 168 & Japan & Industrial production \\
\hline 169 & Japan & Private total fixed capital formation, volume \\
\hline 170 & Japan & Gross total fixed capital formation, volume \\
\hline 171 & Japan & Labor force \\
\hline 172 & Japan & Imports of goods and services, volume, national accounts basis \\
\hline 173 & Japan & Money supply, broad definition: M2 or M3 \\
\hline 174 & Japan & Factor income paid abroad, volume, balance of payments basis \\
\hline 175 & Japan & Labor productivity of the total economy \\
\hline 176 & Japan & Unit labor cost of the manufacturing sector \\
\hline 177 & Japan & Unemployment \\
\hline 178 & Japan & Wage rate of the manufacturing sector, hourly earnings \\
\hline 179 & Japan & Exports of goods and services, volume, national accounts basis \\
\hline 180 & Japan & Factor income from abroad, volume, balance of payments basis \\
\hline 181 & Japan & $\begin{array}{l}\text { JPN Monetary aggregate M1 sa / Quantum (non-additive or stock } \\
\text { figures) SA I yen }\end{array}$ \\
\hline 182 & Japan & Claims on private sector \\
\hline 183 & Japan & $\mathrm{HPI}$ \\
\hline 184 & Japan & SPI \\
\hline 185 & Japan & Direct investment abroad \\
\hline 186 & Japan & Dir. invest. in rep. econ., n.i.e. \\
\hline 187 & Japan & Portfolio investment assets \\
\hline 188 & Japan & Portfolio investment liab., n.i.e \\
\hline 189 & Japan & Other investment liab., n.i.e \\
\hline
\end{tabular}


Annex I. Macroeconomic Series

\begin{tabular}{|c|c|c|}
\hline Series No. & Country/Region & Variable Name \\
\hline 190 & Japan & Financial account, n.i.e. \\
\hline 191 & Japan & Balance of income, value, balance of payments basis \\
\hline 192 & Japan & Current account, value \\
\hline 193 & Japan & Current account, value in US\$ \\
\hline 194 & Japan & Long-term interest rate on government bonds \\
\hline 195 & Japan & Short-term interest rate \\
\hline 196 & Japan & Increase in stocks, volume \\
\hline 197 & Japan & Labor force participation rate \\
\hline 198 & Japan & Unemployment rate \\
\hline 199 & Japan & Velocity of money \\
\hline 200 & Japan & Terms of trade \\
\hline 201 & Japan & Industrial confidence \\
\hline 202 & Japan & Stock prices \\
\hline 203 & Netherlands & Real Effective exchange rate, $2000=100$, ULC-based \\
\hline 204 & Netherlands & Gross domestic product, deflator, market prices \\
\hline 205 & Netherlands & $\mathrm{CPI}$ \\
\hline 206 & Netherlands & Import Unit Values / Import Prices \\
\hline 207 & Netherlands & Export Unit Values / Export Prices \\
\hline 208 & Netherlands & Government consumption of fixed capital, value \\
\hline 209 & Netherlands & Private final consumption expenditure, volume \\
\hline 210 & Netherlands & Total employment \\
\hline 211 & Netherlands & Exchange rate, index of US\$ per local currency \\
\hline 212 & Netherlands & Gross domestic product, volume, market prices \\
\hline 213 & Netherlands & Private non-residential fixed capital formation, volume \\
\hline 214 & Netherlands & Fixed investment in non-residential construction, volume \\
\hline 215 & Netherlands & Fixed investment in construction, volume \\
\hline 216 & Netherlands & Government fixed capital formation, volume \\
\hline 217 & Netherlands & Private residential fixed capital formation, volume \\
\hline 218 & Netherlands & Fixed investment in machinery \& equipment, volume \\
\hline 219 & Netherlands & Industrial production \\
\hline 220 & Netherlands & Private total fixed capital formation, volume \\
\hline 221 & Netherlands & Gross total fixed capital formation, volume \\
\hline 222 & Netherlands & Labor force \\
\hline 223 & Netherlands & Imports of goods and services, volume, national accounts basis \\
\hline 224 & Netherlands & Labor productivity of the total economy \\
\hline 225 & Netherlands & Unit labor cost of the total economy \\
\hline 226 & Netherlands & Unit labor cost of the manufacturing sector \\
\hline 227 & Netherlands & Wage rate of the manufacturing sector, hourly earnings \\
\hline 228 & Netherlands & Exports of goods and services, volume, national accounts basis \\
\hline 229 & Netherlands & Government current disbursements, value \\
\hline 230 & Netherlands & Government current receipts, value \\
\hline 231 & Netherlands & Money supply, broad definition: M2 or M3 \\
\hline 232 & Netherlands & Claims on private sector \\
\hline 233 & Netherlands & $\mathrm{HPI}$ \\
\hline 234 & Netherlands & SPI \\
\hline 235 & Netherlands & TFP growth \\
\hline 236 & Netherlands & Direct investment abroad \\
\hline 237 & Netherlands & Dir. invest. in rep. econ., n.i.e. \\
\hline
\end{tabular}


Annex I. Macroeconomic Series

\begin{tabular}{|c|c|c|}
\hline Series No. & Country/Region & Variable Name \\
\hline 238 & Netherlands & Portfolio investment assets \\
\hline 239 & Netherlands & Portfolio investment liab., n.i.e \\
\hline 240 & Netherlands & Other investment assets \\
\hline 241 & Netherlands & Other investment liab., n.i.e \\
\hline 242 & Netherlands & Financial account, n.i.e. \\
\hline 243 & Netherlands & Capacity utilization \\
\hline 244 & Netherlands & Balance of income, value, balance of payments basis \\
\hline 245 & Netherlands & Current account, value \\
\hline 246 & Netherlands & Current account, value in US\$ \\
\hline 247 & Netherlands & Long-term interest rate on government bonds \\
\hline 248 & Netherlands & Short-term interest rate $\backslash$ PERCENT \\
\hline 249 & Netherlands & Increase in stocks, volume \\
\hline 250 & Netherlands & Labor force participation rate \\
\hline 251 & Netherlands & Government saving(net), value \\
\hline 252 & Netherlands & Unemployment rate \\
\hline 253 & Netherlands & Consumer confidence \\
\hline 254 & Netherlands & Terms of trade \\
\hline 255 & Netherlands & Stock prices \\
\hline 256 & UK & PPI \\
\hline 257 & UK & Real Effective exchange rate, $2000=100$, ULC-based \\
\hline 258 & UK & Gross domestic product deflator \\
\hline 259 & UK & $\mathrm{CPI}$ \\
\hline 260 & UK & Import Unit Values / Import Prices \\
\hline 261 & UK & Export Unit Values / Export Prices \\
\hline 262 & UK & Government consumption of fixed capital, value \\
\hline 263 & UK & Private final consumption expenditure, volume \\
\hline 264 & UK & Dependent employment \\
\hline 265 & UK & Dependent employment of the business sector \\
\hline 266 & UK & Government employment \\
\hline 267 & UK & Self-employed \\
\hline 268 & UK & Total employment \\
\hline 269 & UK & Employment of the business sector \\
\hline 270 & UK & Exchange rate, index of US\$ per local currency \\
\hline 271 & UK & Gross domestic product, constant prices \\
\hline 272 & UK & Private non-residential fixed capital formation, volume \\
\hline 273 & UK & Government fixed capital formation, volume \\
\hline 274 & UK & Private residential fixed capital formation, volume \\
\hline 275 & UK & Industrial production \\
\hline 276 & UK & Private total fixed capital formation, volume \\
\hline 277 & UK & Gross total fixed capital formation, volume \\
\hline 278 & UK & Labor force \\
\hline 279 & UK & Imports of goods and services, volume, national accounts basis \\
\hline 280 & UK & Labor productivity of the total economy \\
\hline 281 & UK & Household saving, value \\
\hline 282 & UK & Current transfers received by households, value \\
\hline 283 & UK & Unit labor cost of the total economy \\
\hline 284 & UK & Unit labor cost of the manufacturing sector \\
\hline 285 & UK & Unemployment \\
\hline
\end{tabular}


Annex I. Macroeconomic Series

\begin{tabular}{|c|c|c|}
\hline Series No. & Country/Region & Variable Name \\
\hline 286 & UK & Wages, value \\
\hline 287 & UK & Wage rate of the business sector \\
\hline 288 & UK & Compensation rate of government employees \\
\hline 289 & UK & Wage rate of the manufacturing sector, hourly earnings \\
\hline 290 & UK & Compensation rate of the business sector \\
\hline 291 & UK & Compensation of employees, value \\
\hline 292 & UK & Exports of goods and services, volume, national accounts basis \\
\hline 293 & UK & Household disposable income, real \\
\hline 294 & UK & Property income received by households, value \\
\hline 295 & UK & Government current disbursements, value \\
\hline 296 & UK & Current disbursements of households, value \\
\hline 297 & UK & Government current receipts, value \\
\hline 298 & UK & Current receipts of households, value \\
\hline 299 & UK & Self-employment income received by households, value \\
\hline 300 & UK & Money supply, broad definition: M2 or M3 \\
\hline 301 & UK & Claims on private sector \\
\hline 302 & UK & $\mathrm{HPI}$ \\
\hline 303 & UK & SPI \\
\hline 304 & UK & Fixed investment of government enterprises, volume \\
\hline 305 & UK & Direct investment abroad \\
\hline 306 & UK & Dir. invest. in rep. econ., n.i.e. \\
\hline 307 & UK & Portfolio investment assets \\
\hline 308 & UK & Portfolio investment liab., n.i.e \\
\hline 309 & UK & Other investment assets \\
\hline 310 & UK & Other investment liab., n.i.e \\
\hline 311 & UK & Financial account, n.i.e. \\
\hline 312 & UK & Capacity utilization \\
\hline 313 & UK & Balance of income, value, balance of payments basis \\
\hline 314 & UK & Current account, value \\
\hline 315 & UK & Current account, value in US\$ \\
\hline 316 & UK & Long-term interest rate on government bonds \\
\hline 317 & UK & Short-term interest rate \\
\hline 318 & UK & Increase in stocks, volume \\
\hline 319 & UK & Labor force participation rate \\
\hline 320 & UK & Government saving(net), value \\
\hline 321 & UK & Household saving ratio \\
\hline 322 & UK & Unemployment rate \\
\hline 323 & UK & Industrial confidence \\
\hline 324 & UK & Terms of trade \\
\hline 325 & UK & Consumer confidence \\
\hline 326 & USA & Real Effective exchange rate, $2000=100$, ULC-based \\
\hline 327 & USA & Gross domestic product deflator \\
\hline 328 & USA & $\mathrm{CPI}$ \\
\hline 329 & USA & Import Unit Values / Import Prices \\
\hline 330 & USA & Export Unit Values / Export Prices \\
\hline 331 & USA & Private final consumption expenditure, volume \\
\hline 332 & USA & Dependent employment \\
\hline 333 & USA & Dependent employment of the business sector \\
\hline
\end{tabular}


Annex I. Macroeconomic Series

\begin{tabular}{|c|c|c|}
\hline Series No. & Country/Region & Variable Name \\
\hline 334 & USA & Government employment \\
\hline 335 & USA & Self-employed \\
\hline 336 & USA & Total employment \\
\hline 337 & USA & Employment of the business sector \\
\hline 338 & USA & Gross domestic product, constant prices \\
\hline 339 & USA & Private non-residential fixed capital formation, volume \\
\hline 340 & USA & Fixed investment in non-residential construction, volume \\
\hline 341 & USA & Fixed investment in construction, volume \\
\hline 342 & USA & Government fixed capital formation, volume \\
\hline 343 & USA & Private residential fixed capital formation, volume \\
\hline 344 & USA & Fixed investment in machinery \& equipment, volume \\
\hline 345 & USA & Industrial production \\
\hline 346 & USA & Private total fixed capital formation, volume \\
\hline 347 & USA & Gross total fixed capital formation, volume \\
\hline 348 & USA & Labor force \\
\hline 349 & USA & Imports of goods and services, volume, national accounts basis \\
\hline 350 & USA & Labor productivity of the total economy \\
\hline 351 & USA & Current transfers received by households, value \\
\hline 352 & USA & Unit labor cost of the total economy \\
\hline 353 & USA & Unit labor cost of the manufacturing sector \\
\hline 354 & USA & Unemployment \\
\hline 355 & USA & Wages, value \\
\hline 356 & USA & Wages of the government sector, value \\
\hline 357 & USA & Wage rate of the business sector \\
\hline 358 & USA & Compensation rate of government employees \\
\hline 359 & USA & Wage rate of the manufacturing sector, hourly earnings \\
\hline 360 & USA & Compensation rate of the business sector \\
\hline 361 & USA & Compensation of employees, value \\
\hline 362 & USA & Exports of goods and services, volume, national accounts basis \\
\hline 363 & USA & Household disposable income, real \\
\hline 364 & USA & Property income received by households, value \\
\hline 365 & USA & Government current disbursements, value \\
\hline 366 & USA & Current disbursements of households, value \\
\hline 367 & USA & Government current receipts, value \\
\hline 368 & USA & Current receipts of households, value \\
\hline 369 & USA & Self-employment income received by households, value \\
\hline 370 & USA & $\begin{array}{l}\text { USA Monetary aggregate M1 sa / Quantum (non-additive or stock } \\
\text { figures) SA I dollars }\end{array}$ \\
\hline 371 & USA & $\begin{array}{l}\text { USA Monetary aggregate M2 sa / Quantum (non-additive or stock } \\
\text { figures) SA I dollars }\end{array}$ \\
\hline 372 & USA & Claims on private sector \\
\hline 373 & USA & $\mathrm{HPI}$ \\
\hline 374 & USA & SPI \\
\hline 375 & USA & Direct investment abroad \\
\hline 376 & USA & Dir. invest. in rep. econ., n.i.e. \\
\hline 377 & USA & Portfolio investment assets \\
\hline 378 & USA & Portfolio investment liab., n.i.e \\
\hline 379 & USA & Other investment assets \\
\hline 380 & USA & Other investment liab., n.i.e \\
\hline
\end{tabular}


Annex I. Macroeconomic Series

\begin{tabular}{|c|c|c|}
\hline Series No. & Country/Region & Variable Name \\
\hline 381 & USA & Financial account, n.i.e. \\
\hline 382 & USA & Balance of income, value, balance of payments basis \\
\hline 383 & USA & Current account, value in US\$ \\
\hline 384 & USA & Long-term interest rate on government bonds \\
\hline 385 & USA & Long-term interest rate on corporate bonds \\
\hline 386 & USA & Short-term interest rate \\
\hline 387 & USA & Increase in stocks, volume \\
\hline 388 & USA & Labor force participation rate \\
\hline 389 & USA & Government saving(net), value \\
\hline 390 & USA & Household saving, value \\
\hline 391 & USA & Household saving ratio \\
\hline 392 & USA & Unemployment rate \\
\hline 393 & USA & Velocity of money \\
\hline 394 & USA & Manufacturing - Industrial confidence indicator \\
\hline 395 & USA & Consumer confidence indicator \\
\hline \multirow[t]{2}{*}{396} & USA & Terms of trade \\
\hline & Trade by Destination & \\
\hline 397 & France & Imports from Euro \\
\hline 398 & Trade by destination & Imports from EU \\
\hline 399 & & Imports from EU ascension countries \\
\hline 400 & & Imports from Canada \\
\hline 401 & & Imports from United States \\
\hline 402 & & Imports from United Kingdom \\
\hline 403 & & Imports from Japan \\
\hline 404 & & Imports from China, P.R.: Mainland \\
\hline 405 & & Imports from Asia \\
\hline 406 & & Imports from Latam \\
\hline 407 & & Imports from ROW \\
\hline 408 & & Exports to Euro \\
\hline 409 & & Exports to EU \\
\hline 410 & & Exports to EU ascension ctrys \\
\hline 411 & & Exports to Canada \\
\hline 412 & & Exports to United States \\
\hline 413 & & Exports to United Kingdom \\
\hline 414 & & Exports to Japan \\
\hline 415 & & Exports to China, P.R.: Mainland \\
\hline 416 & & Exports to Asia \\
\hline 417 & & Exports to Latam \\
\hline 418 & & Exports to ROW \\
\hline 419 & Germany & Imports from Euro \\
\hline 420 & Trade by destination & Imports from EU \\
\hline 421 & & Imports from EU ascension ctrys \\
\hline 422 & & Imports from Canada \\
\hline 423 & & Imports from United States \\
\hline 424 & & Imports from United Kingdom \\
\hline 425 & & Imports from Japan \\
\hline 426 & & Imports from China, P.R.: Mainland \\
\hline
\end{tabular}


Annex I. Macroeconomic Series

\begin{tabular}{|c|c|c|}
\hline Series No. & Country/Region & Variable Name \\
\hline 427 & & Imports from Asia \\
\hline 428 & & Imports from Latam \\
\hline 429 & & Imports from ROW \\
\hline 430 & & Exports to Euro \\
\hline 431 & & Exports to EU \\
\hline 432 & & Exports to EU ascension ctrys \\
\hline 433 & & Exports to Canada \\
\hline 434 & & Exports to United States \\
\hline 435 & & Exports to United Kingdom \\
\hline 436 & & Exports to Japan \\
\hline 437 & & Exports to China, P.R.: Mainland \\
\hline 438 & & Exports to Asia \\
\hline 439 & & Exports to Latam \\
\hline 440 & & Exports to ROW \\
\hline 441 & Japan & Imports from Euro \\
\hline 442 & Trade by destination & Imports from EU \\
\hline 443 & & Imports from EU ascension ctrys \\
\hline 444 & & Imports from Canada \\
\hline 445 & & Imports from United States \\
\hline 446 & & Imports from United Kingdom \\
\hline 447 & & Imports from China, P.R.: Mainland \\
\hline 448 & & Imports from Asia \\
\hline 449 & & Imports from Latam \\
\hline 450 & & Imports from ROW \\
\hline 451 & & Exports to Euro \\
\hline 452 & & Exports to EU \\
\hline 453 & & Exports to EU ascension ctrys \\
\hline 454 & & Exports to Canada \\
\hline 455 & & Exports to United States \\
\hline 456 & & Exports to United Kingdom \\
\hline 457 & & Exports to China, P.R.: Mainland \\
\hline 458 & & Exports to Asia \\
\hline 459 & & Exports to Latam \\
\hline 460 & & Exports to ROW \\
\hline 461 & Netherlands & Imports from Euro \\
\hline 462 & Trade by destination & Imports from EU \\
\hline 463 & & Imports from EU ascension ctrys \\
\hline 464 & & Imports from Canada \\
\hline 465 & & Imports from United States \\
\hline 466 & & Imports from United Kingdom \\
\hline 467 & & Imports from Japan \\
\hline 468 & & Imports from China, P.R.: Mainland \\
\hline 469 & & Imports from Asia \\
\hline 470 & & Imports from Latam \\
\hline 471 & & Imports from ROW \\
\hline 472 & & Exports to Euro \\
\hline 473 & & Exports to EU \\
\hline 474 & & Exports to EU ascension ctrys \\
\hline
\end{tabular}


Annex I. Macroeconomic Series

\begin{tabular}{|c|c|c|}
\hline Series No. & Country/Region & Variable Name \\
\hline 475 & & Exports to Canada \\
\hline 476 & & Exports to United States \\
\hline 477 & & Exports to United Kingdom \\
\hline 478 & & Exports to Japan \\
\hline 479 & & Exports to China, P.R.: Mainland \\
\hline 480 & & Exports to Asia \\
\hline 481 & & Exports to Latam \\
\hline 482 & & Exports to ROW \\
\hline 483 & USA & Imports from Euro \\
\hline 484 & Trade by destination & Imports from EU \\
\hline 485 & & Imports from EU ascension ctrys \\
\hline 486 & & Imports from Canada \\
\hline 487 & & Imports from United Kingdom \\
\hline 488 & & Imports from Japan \\
\hline 489 & & Imports from China, P.R.: Mainland \\
\hline 490 & & Imports from Asia \\
\hline 491 & & Imports from Latam \\
\hline 492 & & Imports from ROW \\
\hline 493 & & Exports to Euro \\
\hline 494 & & Exports to EU \\
\hline 495 & & Exports to EU ascension ctrys \\
\hline 496 & & Exports to Canada \\
\hline 497 & & Exports to United Kingdom \\
\hline 498 & & Exports to Japan \\
\hline 499 & & Exports to China, P.R.: Mainland \\
\hline 500 & & Exports to Asia \\
\hline 501 & & Exports to Latam \\
\hline \multirow[t]{2}{*}{502} & & Exports to ROW \\
\hline & Trade by Product & \\
\hline 397 & France & IMP SITC Total \\
\hline 398 & Trade by product & IMP SITC 0: Food and live animal \\
\hline 399 & & IMP SITC 1: Beverages and tobacco \\
\hline 400 & & IMP SITC 2: Crude materials, inedible, except fuels \\
\hline 401 & & IMP SITC 3: Mineral fuels, lubricants and related materials \\
\hline 402 & & IMP SITC 4: Animal and vegetable oils, fats and waxes \\
\hline 403 & & IMP SITC 5: Chemicals and related products, n.e.s. \\
\hline 404 & & IMP SITC 6: Manufactured goods \\
\hline 405 & & IMP SITC 7: Machinery and transport equipment \\
\hline 406 & & IMP SITC 8: Miscellaneous manufactured articles \\
\hline 407 & & IMP SITC 9: Commodities and transactions n.e.c. \\
\hline 408 & & EXP SITC Total \\
\hline 409 & & EXP SITC 0: Food and live animal \\
\hline 410 & & EXP SITC 1: Beverages and tobacco \\
\hline 411 & & EXP SITC 2: Crude materials, inedible, except fuels \\
\hline 412 & & EXP SITC 3: Mineral fuels, lubricants and related materials \\
\hline 413 & & EXP SITC 4: Animal and vegetable oils, fats and waxes \\
\hline 414 & & EXP SITC 5: Chemicals and related products, n.e.s. \\
\hline
\end{tabular}


Annex I. Macroeconomic Series

\begin{tabular}{|c|c|c|}
\hline Series No. & Country/Region & Variable Name \\
\hline 415 & & EXP SITC 6: Manufactured goods \\
\hline 416 & & EXP SITC 7: Machinery and transport equipment \\
\hline 417 & & EXP SITC 8: Miscellaneous manufactured articles \\
\hline 418 & & EXP SITC 9: Commodities and transactions n.e.c. \\
\hline 419 & Germany & IMP SITC Total \\
\hline 420 & Trade by product & IMP SITC 0: Food and live animal \\
\hline 421 & & IMP SITC 1: Beverages and tobacco \\
\hline 422 & & IMP SITC 2: Crude materials, inedible, except fuels \\
\hline 423 & & IMP SITC 3: Mineral fuels, lubricants and related materials \\
\hline 424 & & IMP SITC 4: Animal and vegetable oils, fats and waxes \\
\hline 425 & & IMP SITC 5: Chemicals and related products, n.e.s. \\
\hline 426 & & IMP SITC 6: Manufactured goods - Germany \\
\hline 427 & & IMP SITC 7: Machinery and transport equipment \\
\hline 428 & & IMP SITC 8: Miscellaneous manufactured articles \\
\hline 429 & & IMP SITC 9: Commodities and transactions n.e.c. \\
\hline 430 & & EXP SITC Total \\
\hline 431 & & EXP SITC 0: Food and live animal \\
\hline 432 & & EXP SITC 1: Beverages and tobacco \\
\hline 433 & & EXP SITC 2: Crude materials, inedible, except fuels \\
\hline 434 & & EXP SITC 3: Mineral fuels, lubricants and related materials \\
\hline 435 & & EXP SITC 4: Animal and vegetable oils, fats and waxes \\
\hline 436 & & EXP SITC 5: Chemicals and related products, n.e.s. \\
\hline 437 & & EXP SITC 6: Manufactured goods \\
\hline 438 & & EXP SITC 7: Machinery and transport equipment \\
\hline 439 & & EXP SITC 8: Miscellaneous manufactured articles \\
\hline 440 & & EXP SITC 9: Commodities and transactions n.e.c. \\
\hline 441 & Japan & IMP SITC Total \\
\hline 442 & Trade by product & IMP SITC 0: Food and live animal \\
\hline 443 & & IMP SITC 1: Beverages and tobacco \\
\hline 444 & & IMP SITC 2: Crude materials, inedible, except fuels \\
\hline 445 & & IMP SITC 3: Mineral fuels, lubricants and related materials \\
\hline 446 & & IMP SITC 4: Animal and vegetable oils, fats and waxes \\
\hline 447 & & IMP SITC 5: Chemicals and related products, n.e.s. \\
\hline 448 & & IMP SITC 6: Manufactured goods - Japan \\
\hline 449 & & IMP SITC 7: Machinery and transport equipment \\
\hline 450 & & IMP SITC 8: Miscellaneous manufactured articles \\
\hline 451 & & IMP SITC 9: Commodities and transactions n.e.c. \\
\hline 452 & & EXP SITC Total \\
\hline 453 & & EXP SITC 0: Food and live animal \\
\hline 454 & & EXP SITC 1: Beverages and tobacco \\
\hline 455 & & EXP SITC 2: Crude materials, inedible, except fuels \\
\hline 456 & & EXP SITC 3: Mineral fuels, lubricants and related materials \\
\hline 457 & & EXP SITC 4: Animal and vegetable oils, fats and waxes \\
\hline 458 & & EXP SITC 5: Chemicals and related products, n.e.s. \\
\hline 459 & & EXP SITC 6: Manufactured goods \\
\hline 460 & & EXP SITC 7: Machinery and transport equipment \\
\hline 461 & & EXP SITC 8: Miscellaneous manufactured articles \\
\hline 462 & & EXP SITC 9: Commodities and transactions n.e.c. \\
\hline
\end{tabular}


Annex I. Macroeconomic Series

\begin{tabular}{|c|c|c|}
\hline Series No. & Country/Region & Variable Name \\
\hline 463 & Netherlands & IMP SITC Total \\
\hline 464 & Trade by product & IMP SITC 0: Food and live animal \\
\hline 465 & & IMP SITC 1: Beverages and tobacco \\
\hline 466 & & IMP SITC 2: Crude materials, inedible, except fuels \\
\hline 467 & & IMP SITC 3: Mineral fuels, lubricants and related materials \\
\hline 468 & & IMP SITC 4: Animal and vegetable oils, fats and waxes \\
\hline 469 & & IMP SITC 5: Chemicals and related products, n.e.s. \\
\hline 470 & & IMP SITC 6: Manufactured goods \\
\hline 471 & & IMP SITC 7: Machinery and transport equipment \\
\hline 472 & & IMP SITC 8: Miscellaneous manufactured articles \\
\hline 473 & & IMP SITC 9: Commodities and transactions n.e.c. \\
\hline 474 & & EXP SITC Total \\
\hline 475 & & EXP SITC 0: Food and live animal \\
\hline 476 & & EXP SITC 1: Beverages and tobacco \\
\hline 477 & & EXP SITC 2: Crude materials, inedible, except fuels \\
\hline 478 & & EXP SITC 3: Mineral fuels, lubricants and related materials \\
\hline 479 & & EXP SITC 4: Animal and vegetable oils, fats and waxes \\
\hline 480 & & EXP SITC 5: Chemicals and related products, n.e.s. \\
\hline 481 & & EXP SITC 6: Manufactured goods \\
\hline 482 & & EXP SITC 7: Machinery and transport equipment \\
\hline 483 & & EXP SITC 8: Miscellaneous manufactured articles \\
\hline 484 & & EXP SITC 9: Commodities and transactions n.e.c. \\
\hline 485 & USA & IMP SITC Total \\
\hline 486 & Trade by product & IMP SITC 0: Food and live animal \\
\hline 487 & & IMP SITC 1: Beverages and tobacco \\
\hline 488 & & IMP SITC 2: Crude materials, inedible, except fuels \\
\hline 489 & & IMP SITC 3: Mineral fuels, lubricants and related materials \\
\hline 490 & & IMP SITC 4: Animal and vegetable oils, fats and waxes \\
\hline 491 & & IMP SITC 5: Chemicals and related products, n.e.s. \\
\hline 492 & & IMP SITC 6: Manufactured goods \\
\hline 493 & & IMP SITC 7: Machinery and transport equipment \\
\hline 494 & & IMP SITC 8: Miscellaneous manufactured articles \\
\hline 495 & & IMP SITC 9: Commodities and transactions n.e.c. \\
\hline 496 & & EXP SITC Total \\
\hline 497 & & EXP SITC 0: Food and live animal \\
\hline 498 & & EXP SITC 1: Beverages and tobacco \\
\hline 499 & & EXP SITC 2: Crude materials, inedible, except fuels \\
\hline 500 & & EXP SITC 3: Mineral fuels, lubricants and related materials \\
\hline 501 & & EXP SITC 4: Animal and vegetable oils, fats and waxes \\
\hline 502 & & EXP SITC 5: Chemicals and related products, n.e.s. \\
\hline 503 & & EXP SITC 6: Manufactured goods \\
\hline 504 & & EXP SITC 7: Machinery and transport equipment \\
\hline 505 & & EXP SITC 8: Miscellaneous manufactured articles \\
\hline 506 & & EXP SITC 9: Commodities and transactions n.e.c. \\
\hline
\end{tabular}




\section{Annex II. France and Germany: Shocks to ULCM and TOT}

\section{France: Shocks to ULCM}
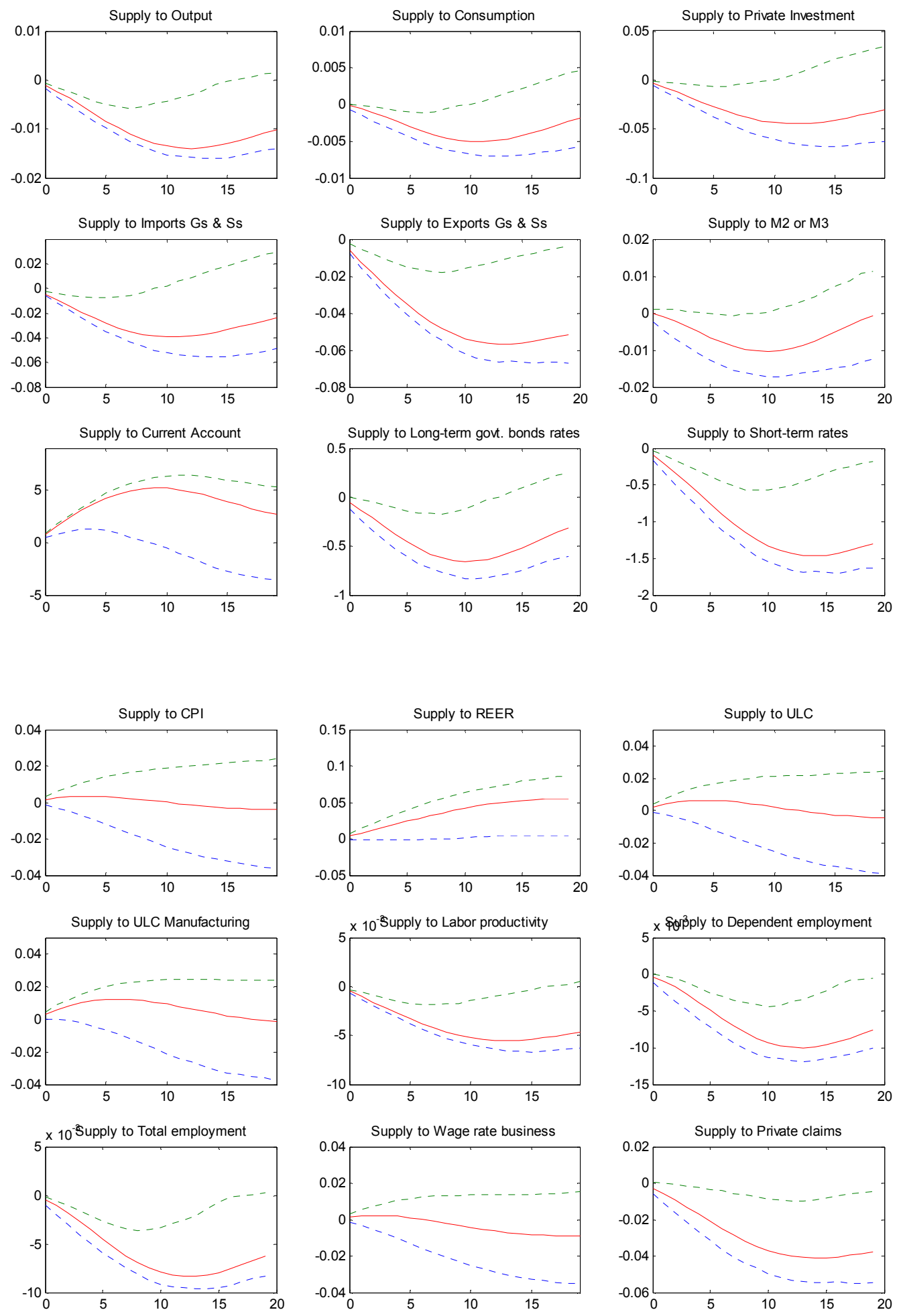

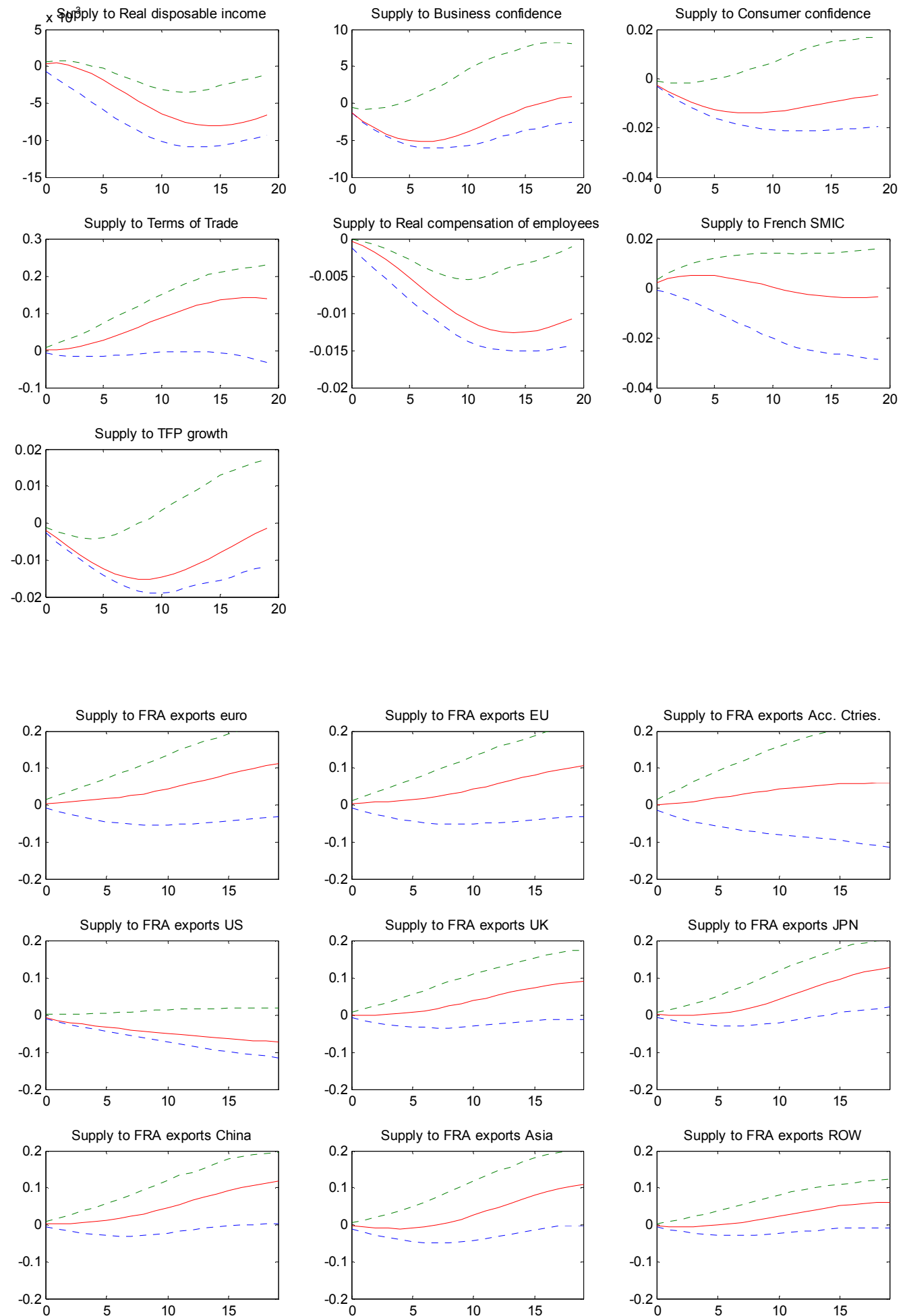

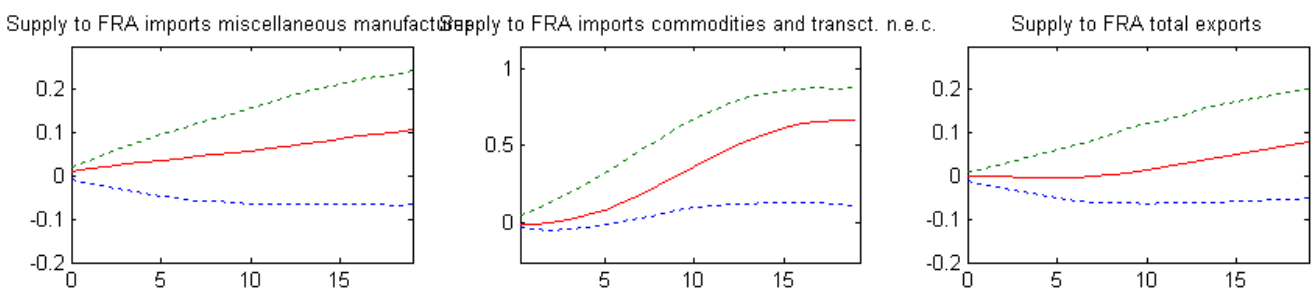

Supply to FRA exports food \& live animal

Supply to FRA exports beveridges and tobacco Supply to FRA exports crude materials excp. fuels
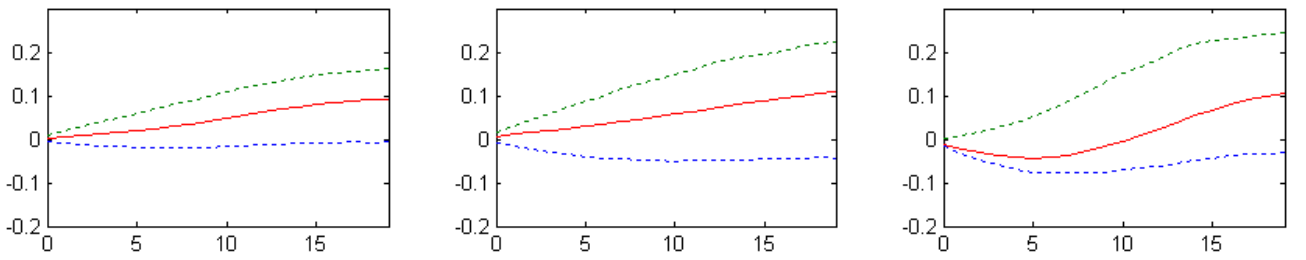

Supply to FRA exports mineral fuels and lubricant\$upply to FRA exports animal \& vegetable oils, fafispply to FRA exports chemicals \& related products
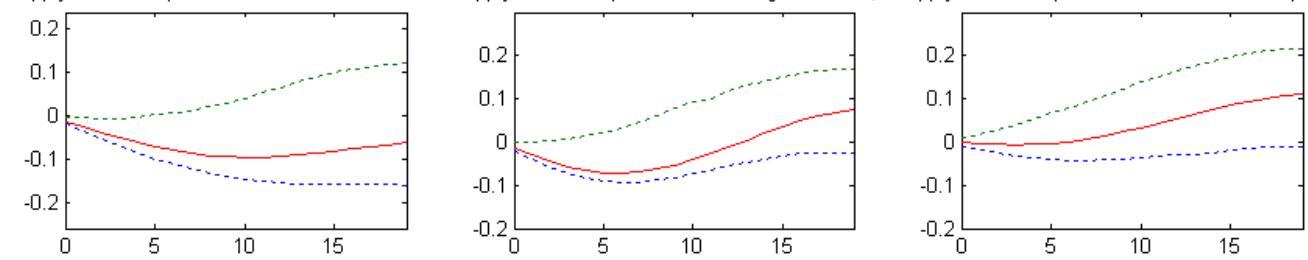

Supply to FRA exports manufacturd goodsSupply to FRA exports machinery \& transport equipmeitupply to FRA exports miscellaneous products
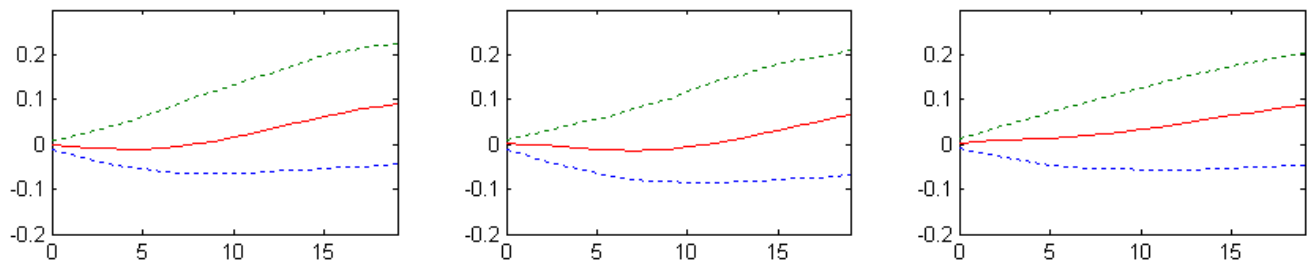

Supply to FRA exports commodities and transact. n.e.c.

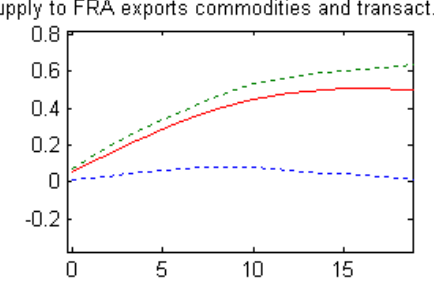



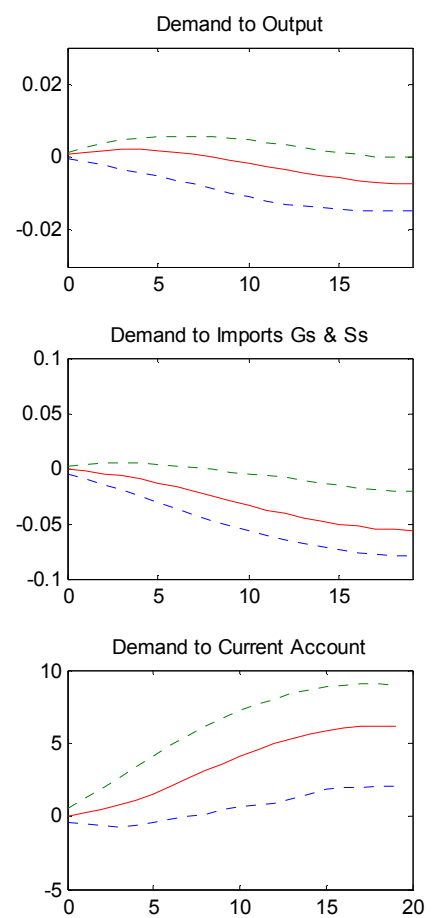

Demand to CP
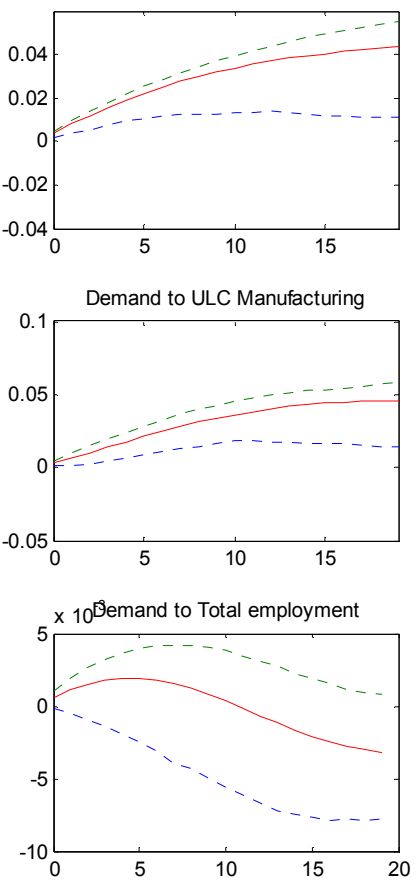

Demand to Consumption

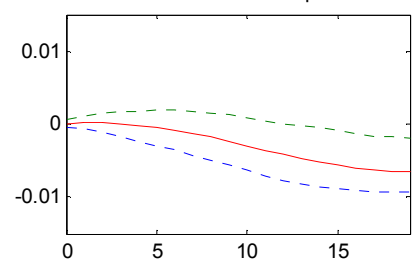

Demand to Exports Gs \& Ss

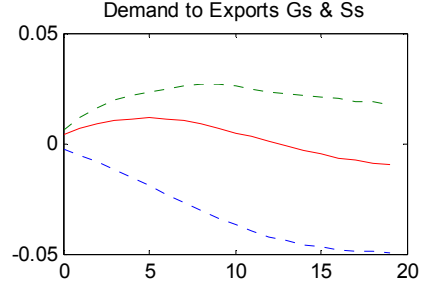

Demand to Long-term govt. bonds rates

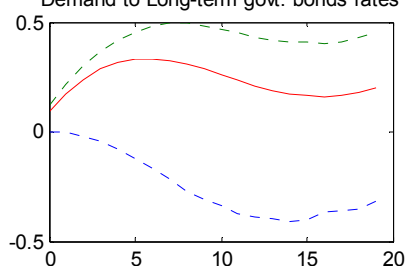

Demand to REER
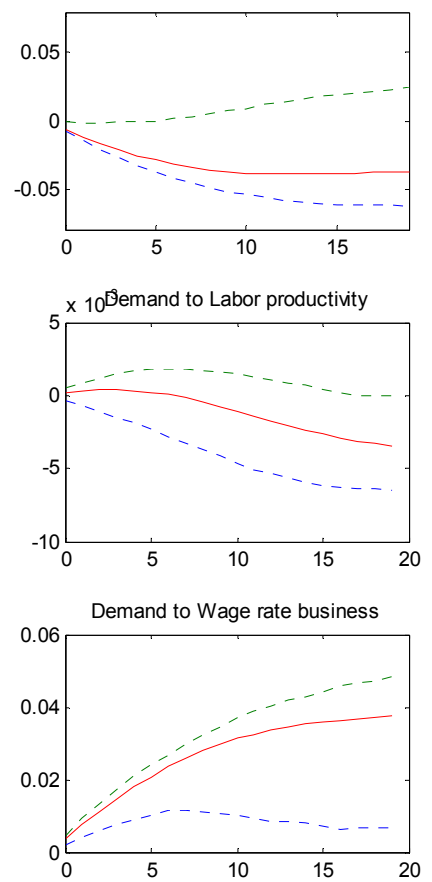
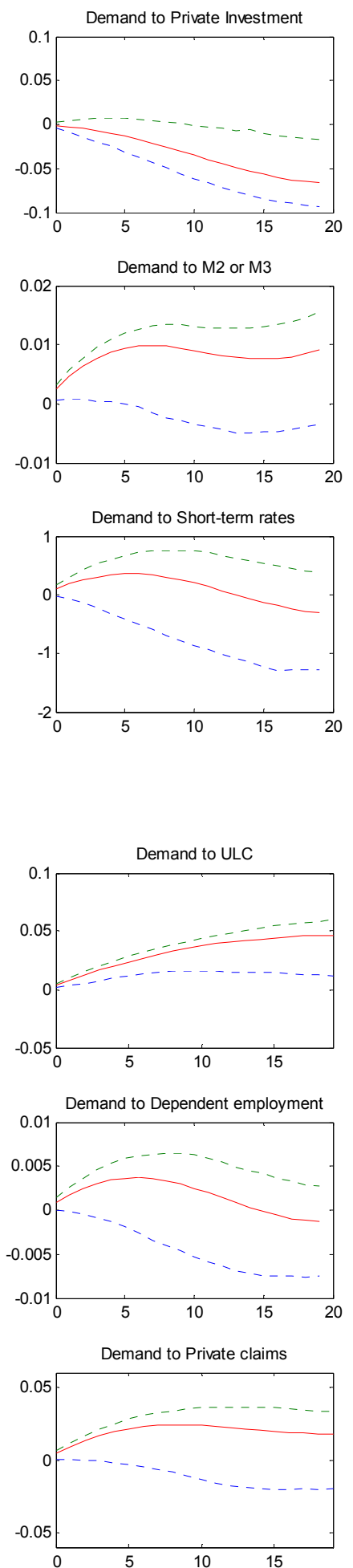


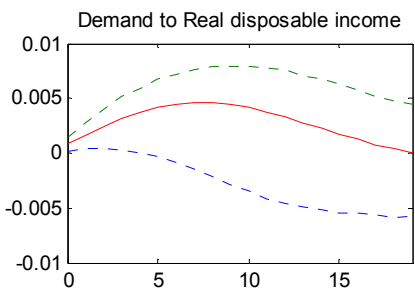

Demand to Terms of Trade
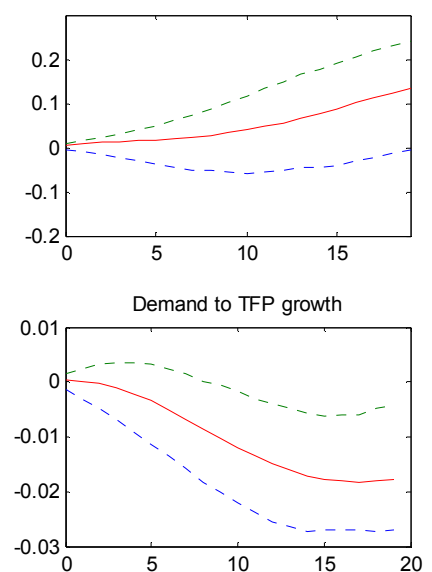

Demand to FRA exports euro

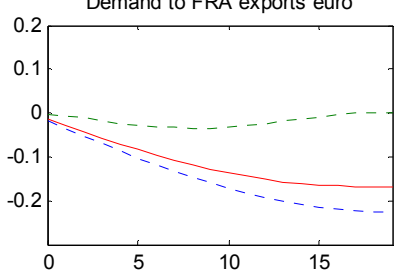

Demand to FRA exports US
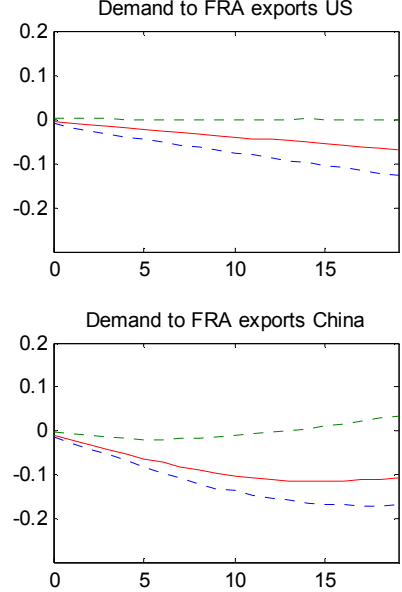

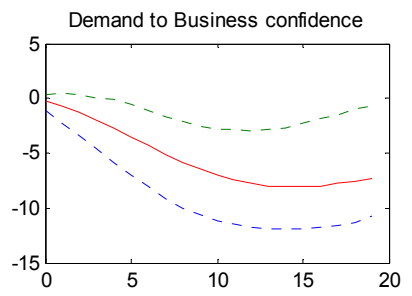

Demand to Real compensation of employees
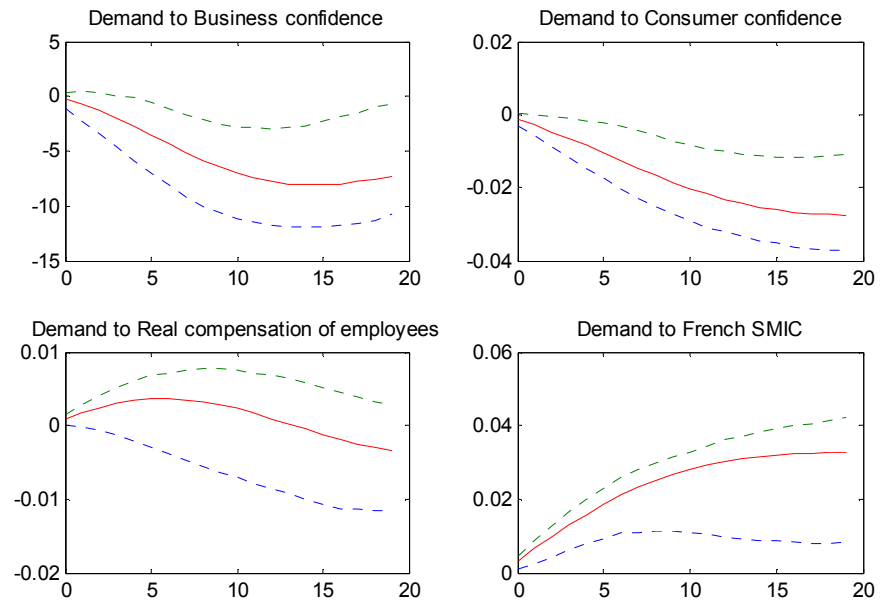
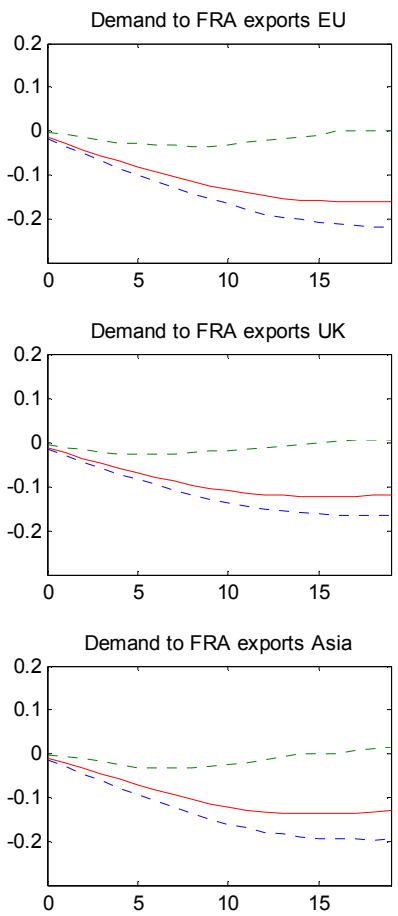
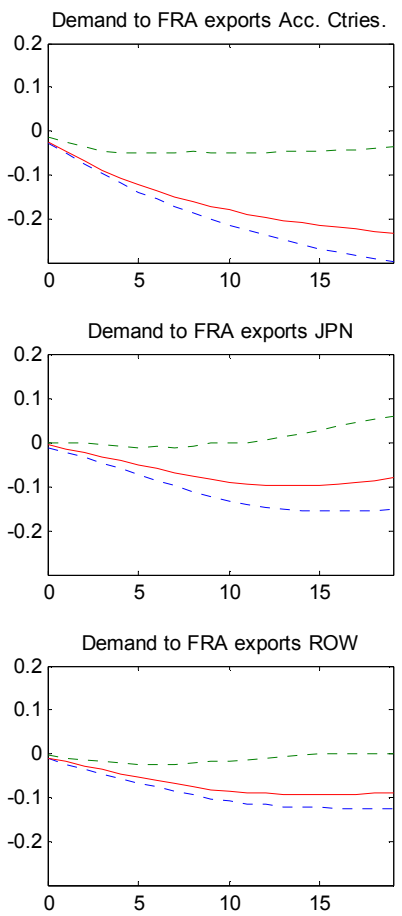
Demand to FRA imports miscellaneous manufactlege
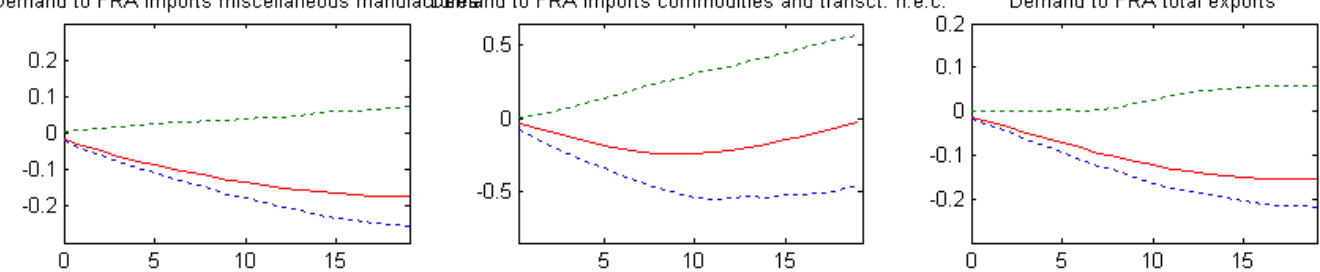

Demand to FRA exports food \& live animal

Demand to FRA exports beveridges and tobaccoDemand to FRA exports crude materials excp. fuels
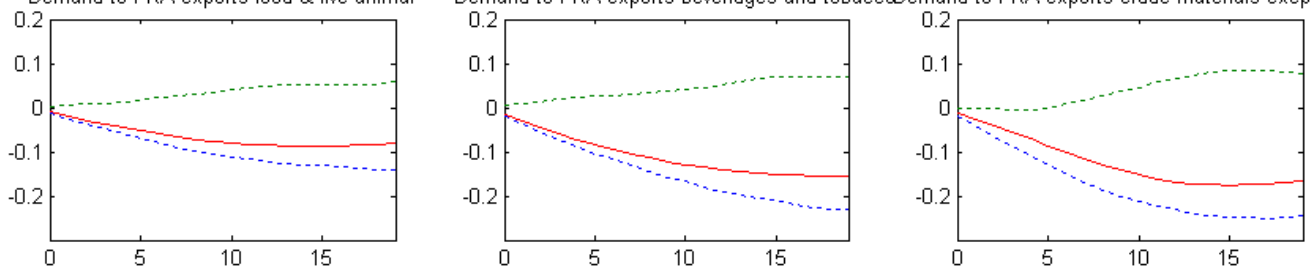

Demand to FRA exports mineral fuels and lubricantemand to FRA exports animal \& vegetable oils, Emand to FRA exports chemicals \& related products
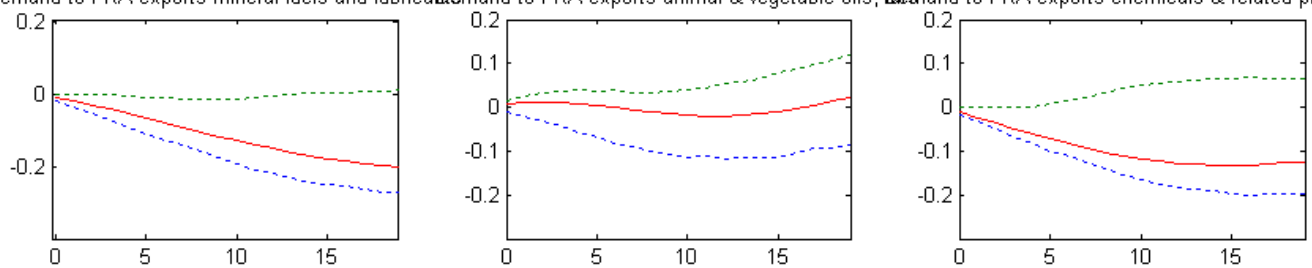

Demand to FRA exports manufacturd goodlemand to FRA exports machinery \& transport equipmleetnand to FRA exports miscellaneous products
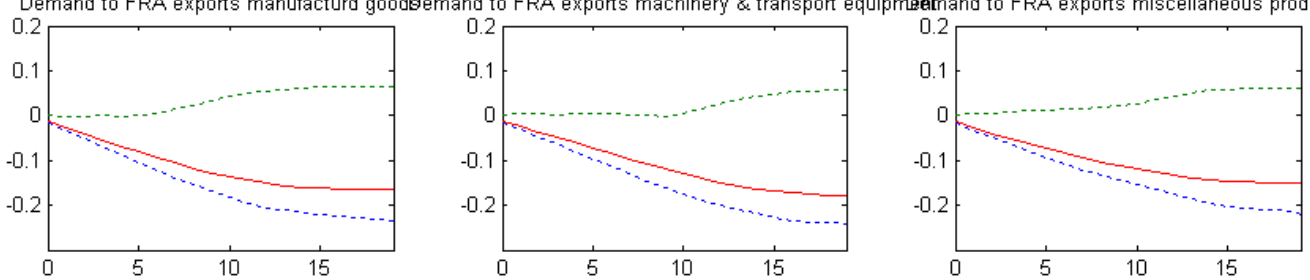

Demand to FRA exports commodities and transact. n.e.c.

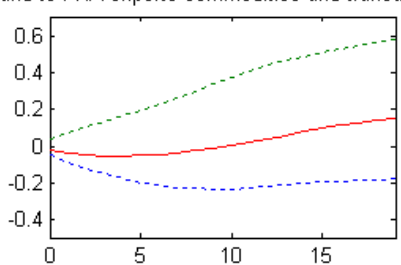




\section{France: Shocks to TOT}
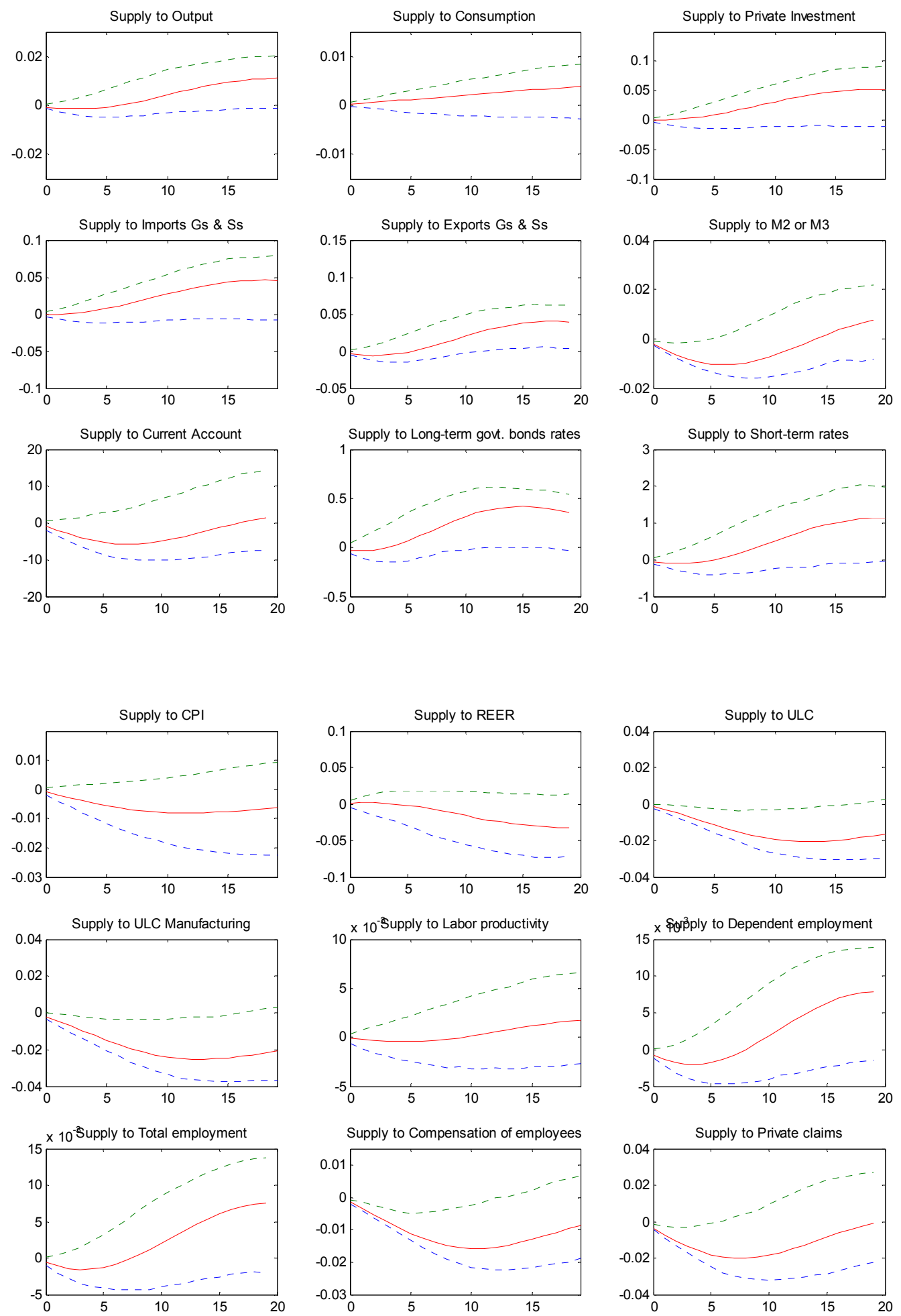

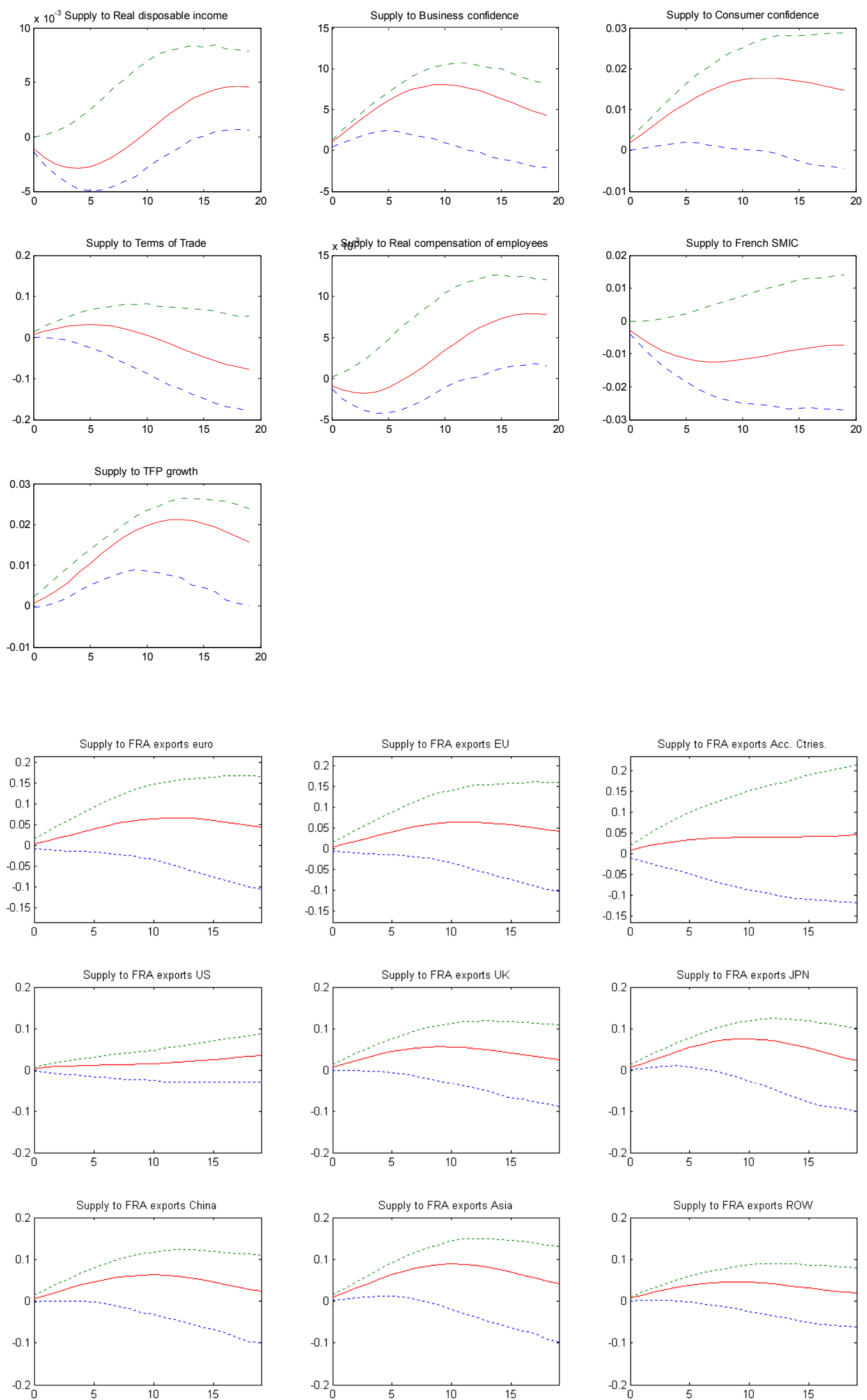

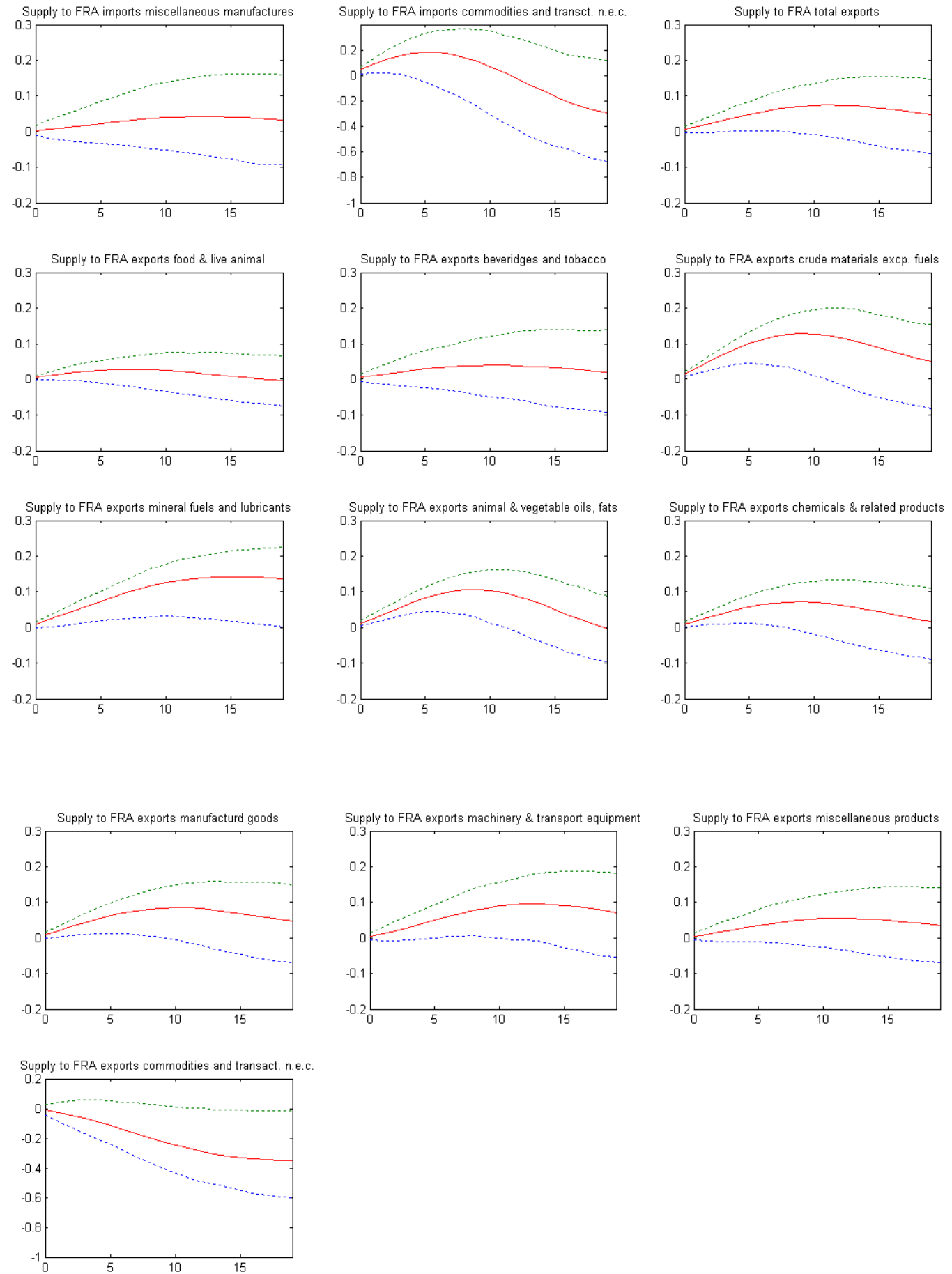

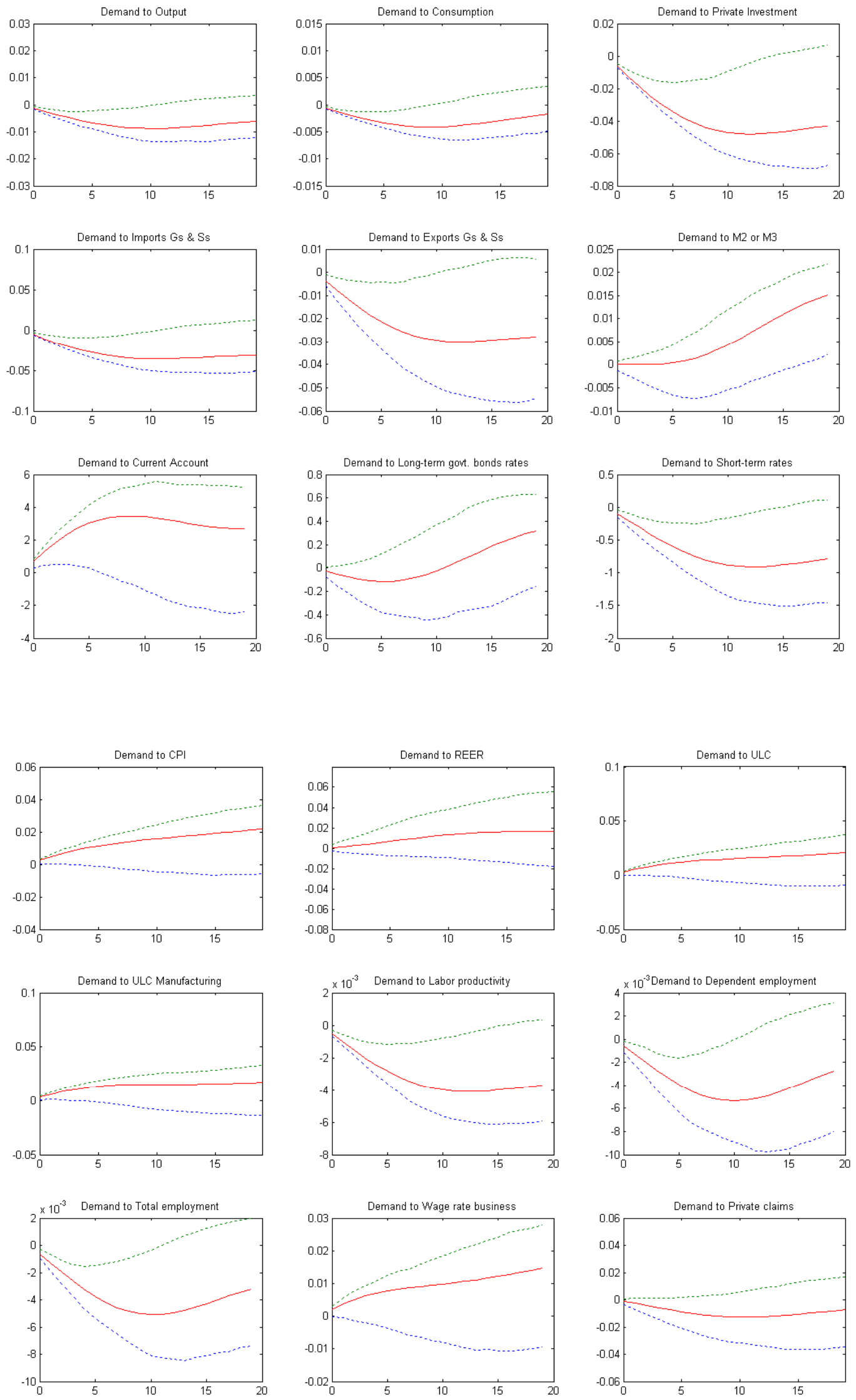

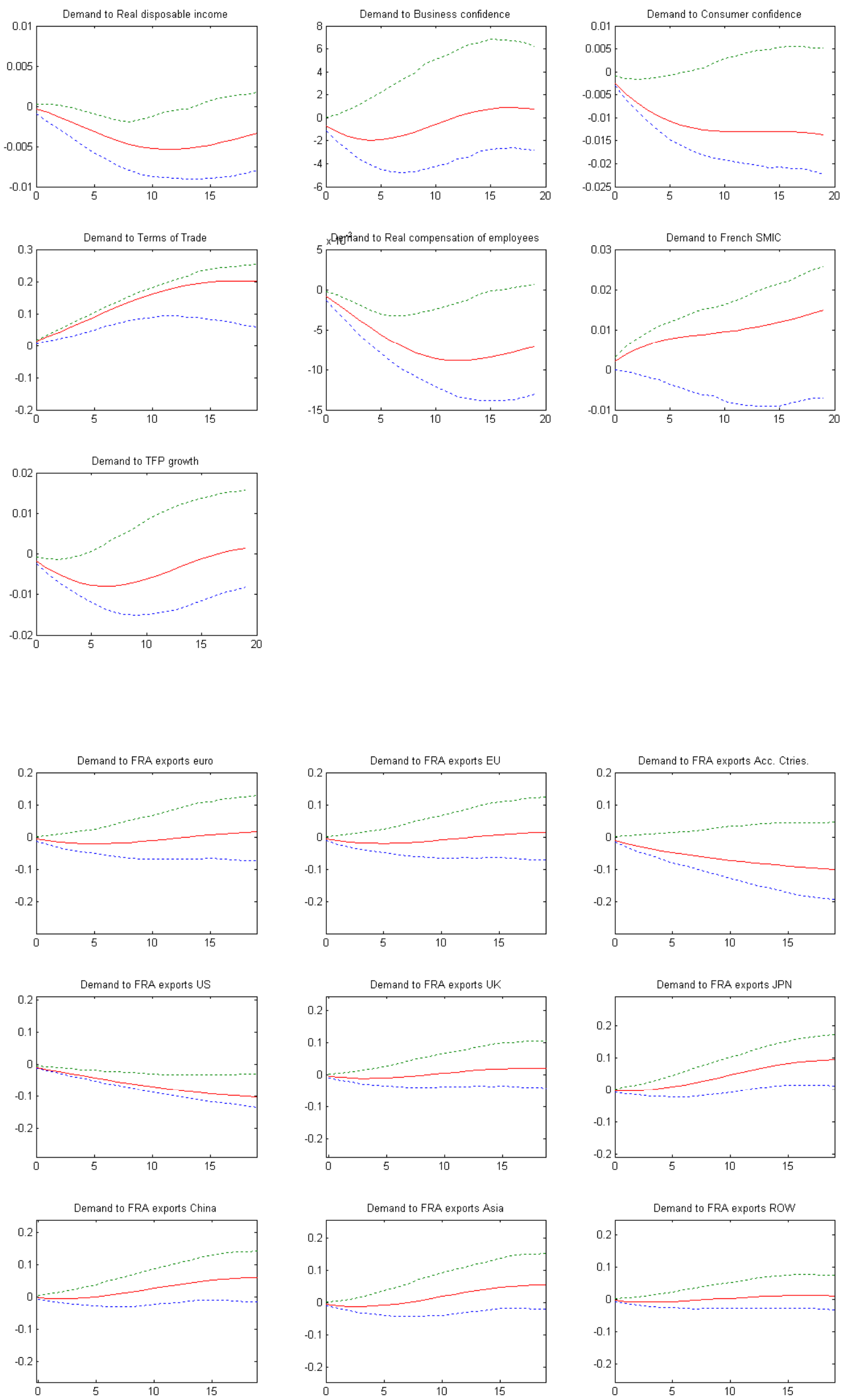

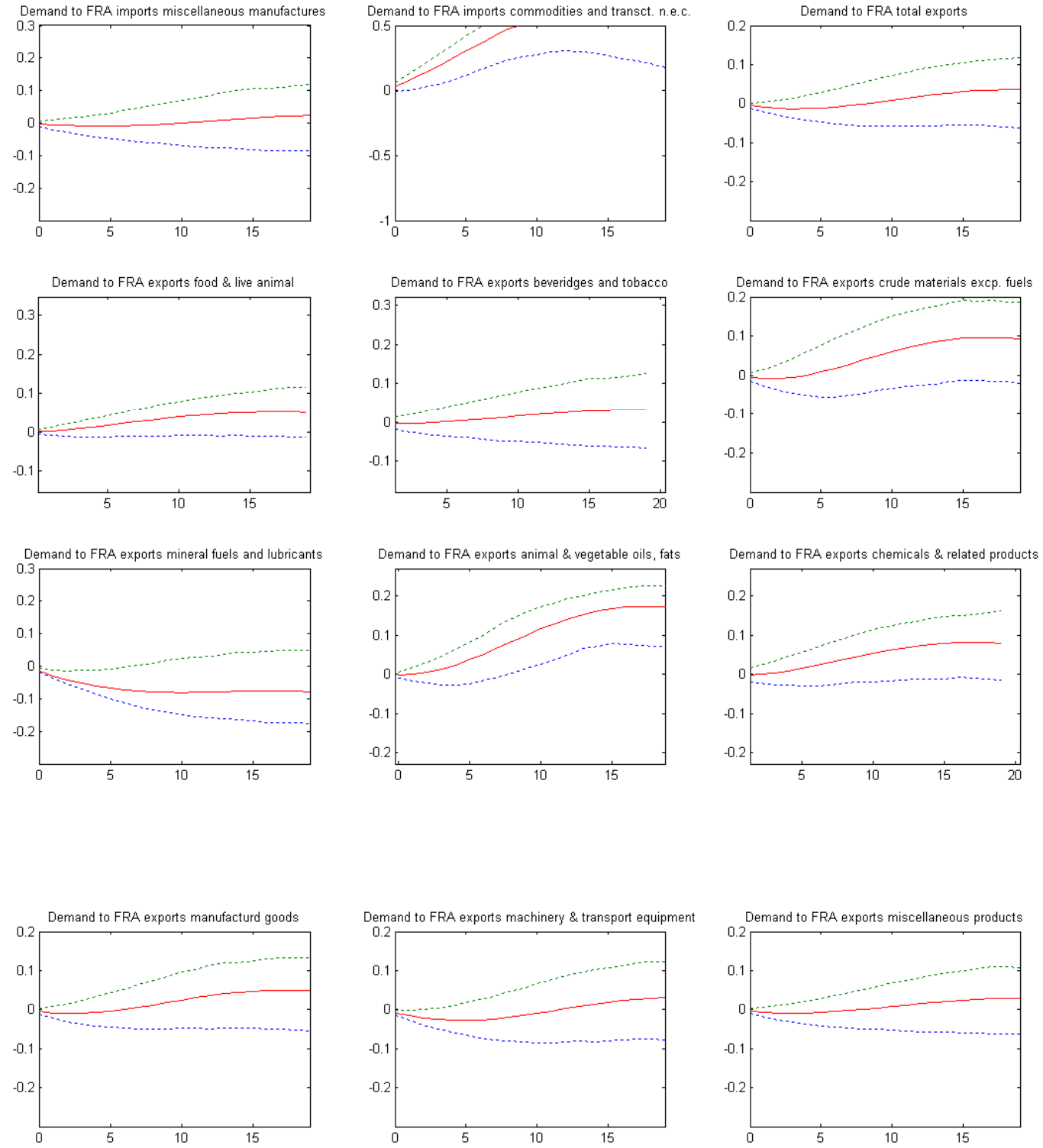

Demand to FRA exports commodities and transact. n.e.c.

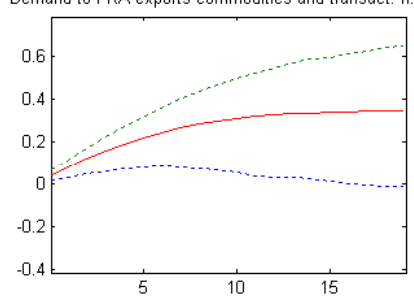




\section{Germany: Shocks to ULCM}
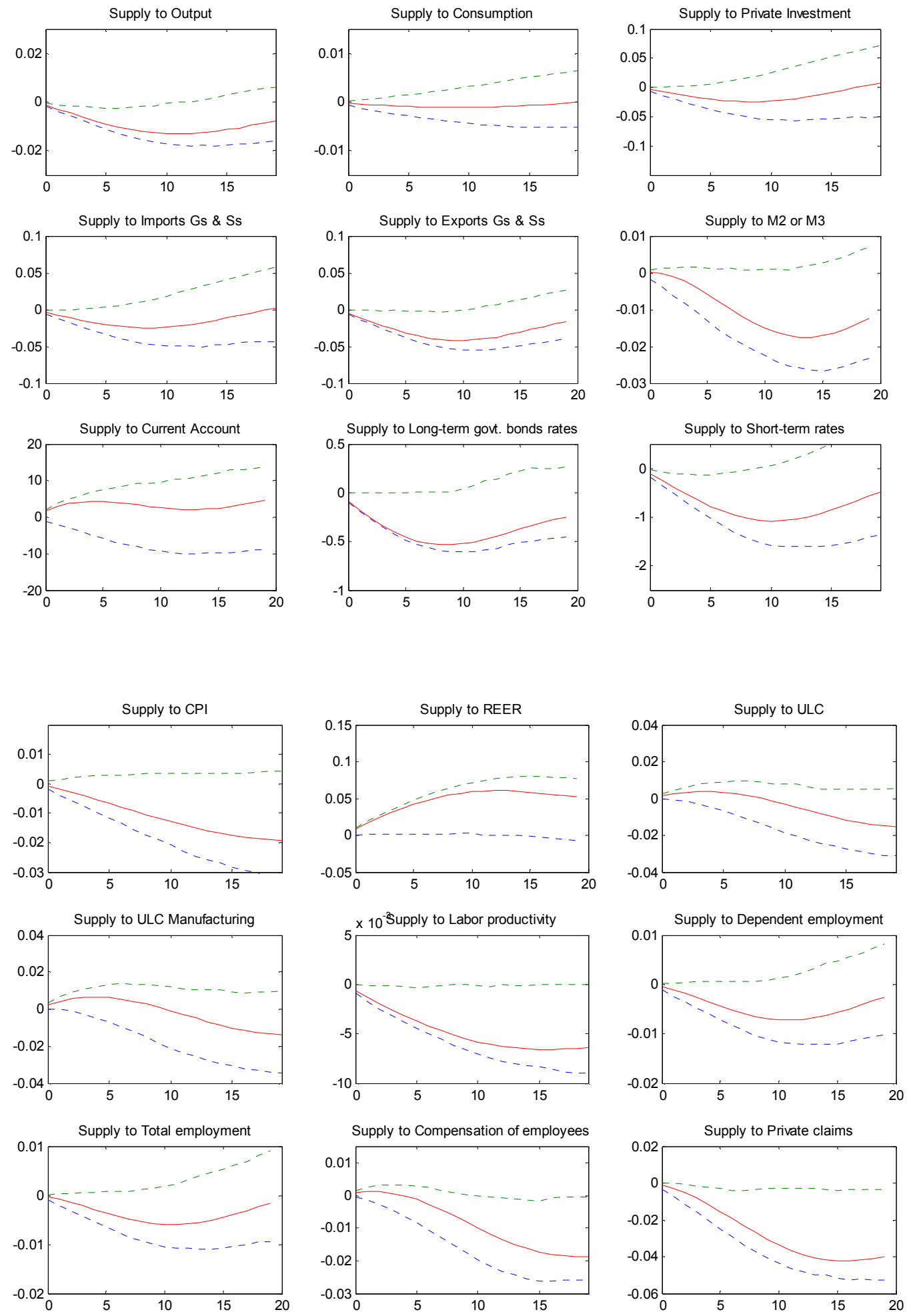

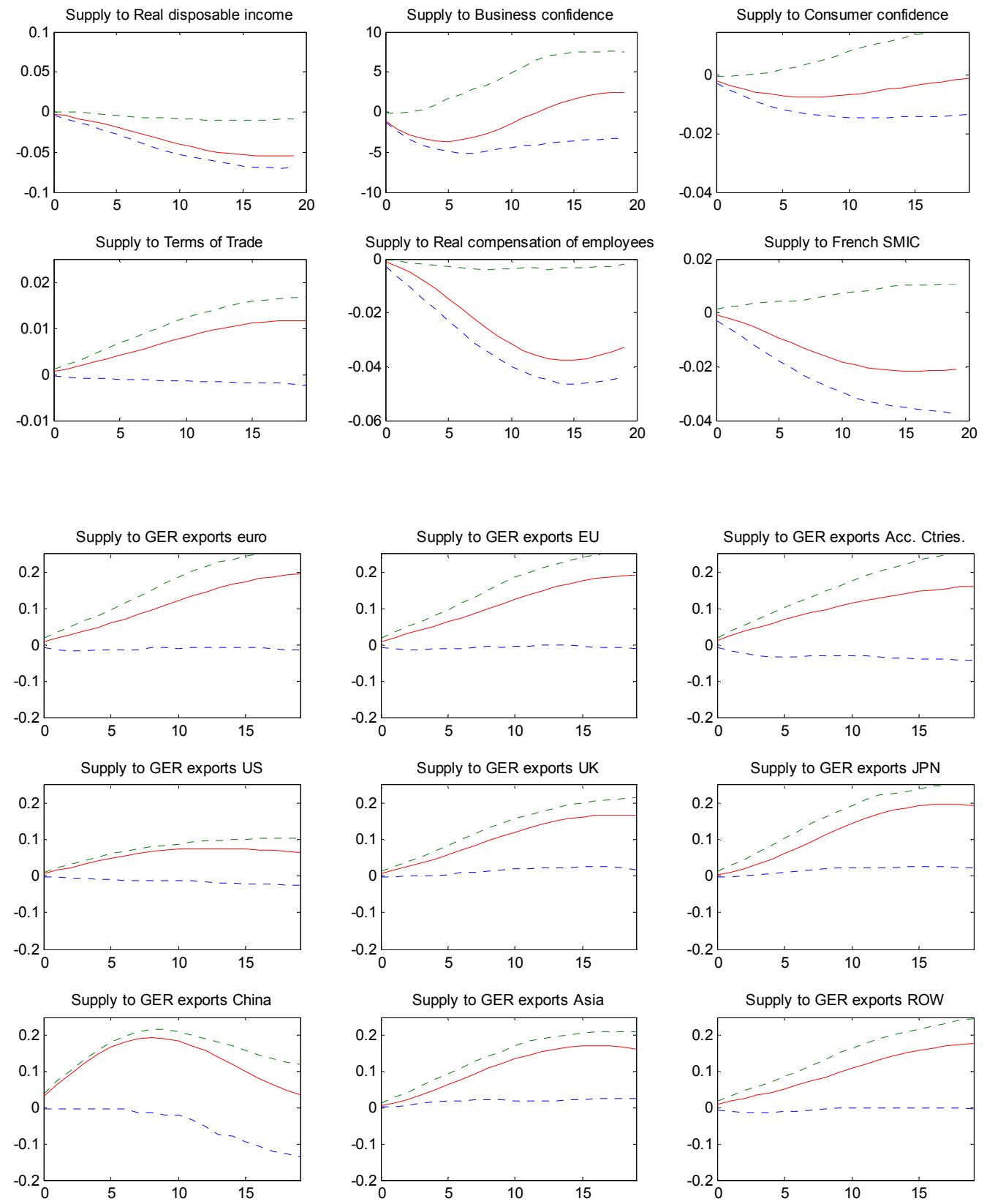
Supply to GER imports miscellaneous manufacterefaply to GER imports commodities and transct. n.e.c. Supply to GER total exports
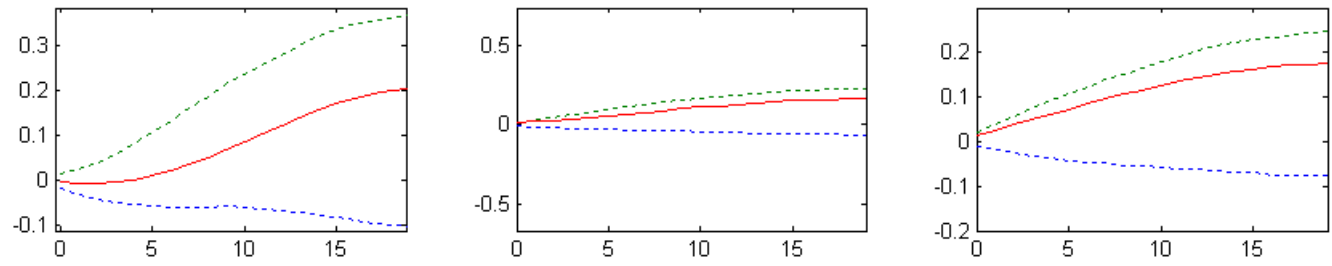

Supply to GER exports food \& live animal

Supply to GER exports beveridges and tobacco Supply to GER exports crude materials excp. fuels
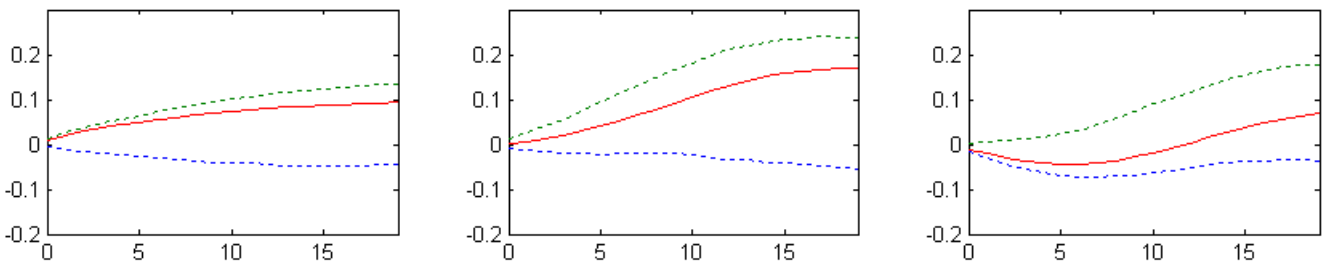

Supply to GER exports mineral fuels and lubrican\&upply to GER exports animal \& vegetable oils, fizepply to GER exports chemicals \& related products
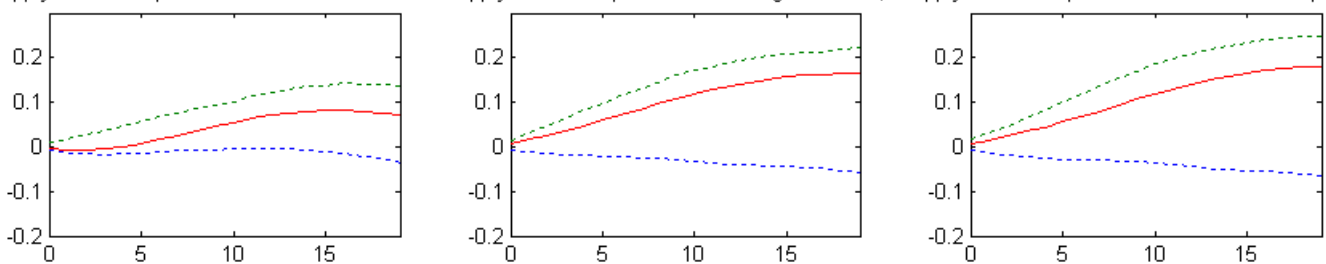

Supply to GER exports manufacturd goodsSupply to GER exports machinery \& transport equipmeginpply to GER exports miscellaneous products
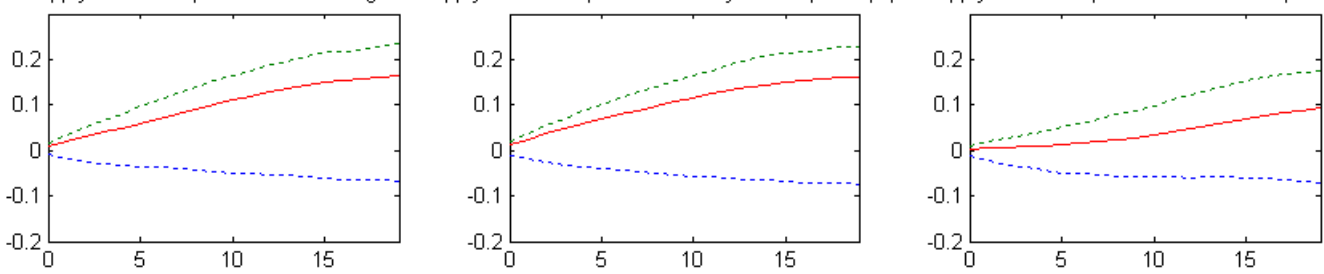

Supply to GER exports commodities and transact. n.e.c.

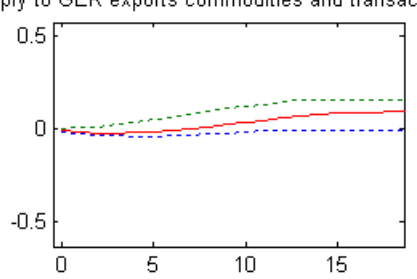



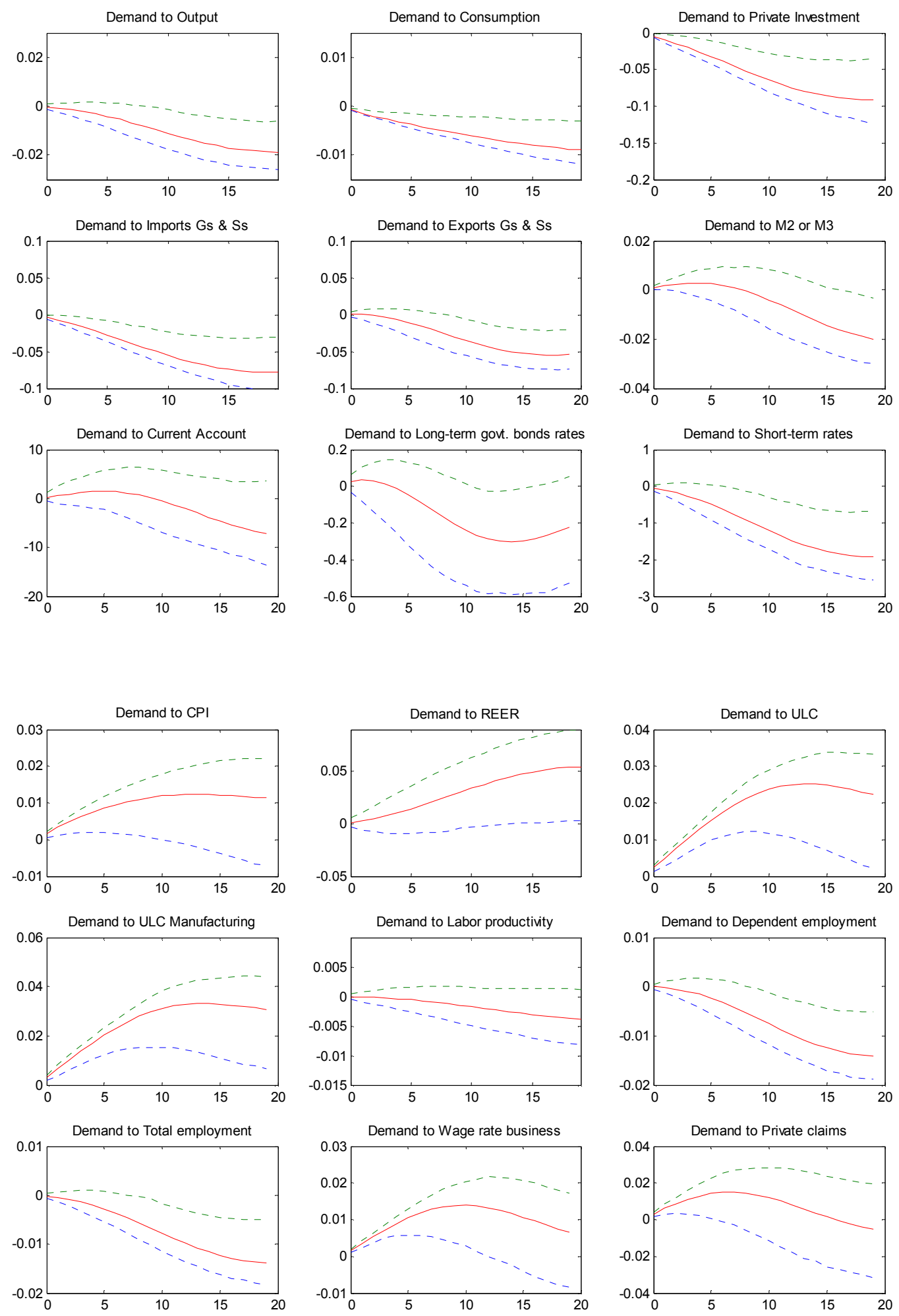

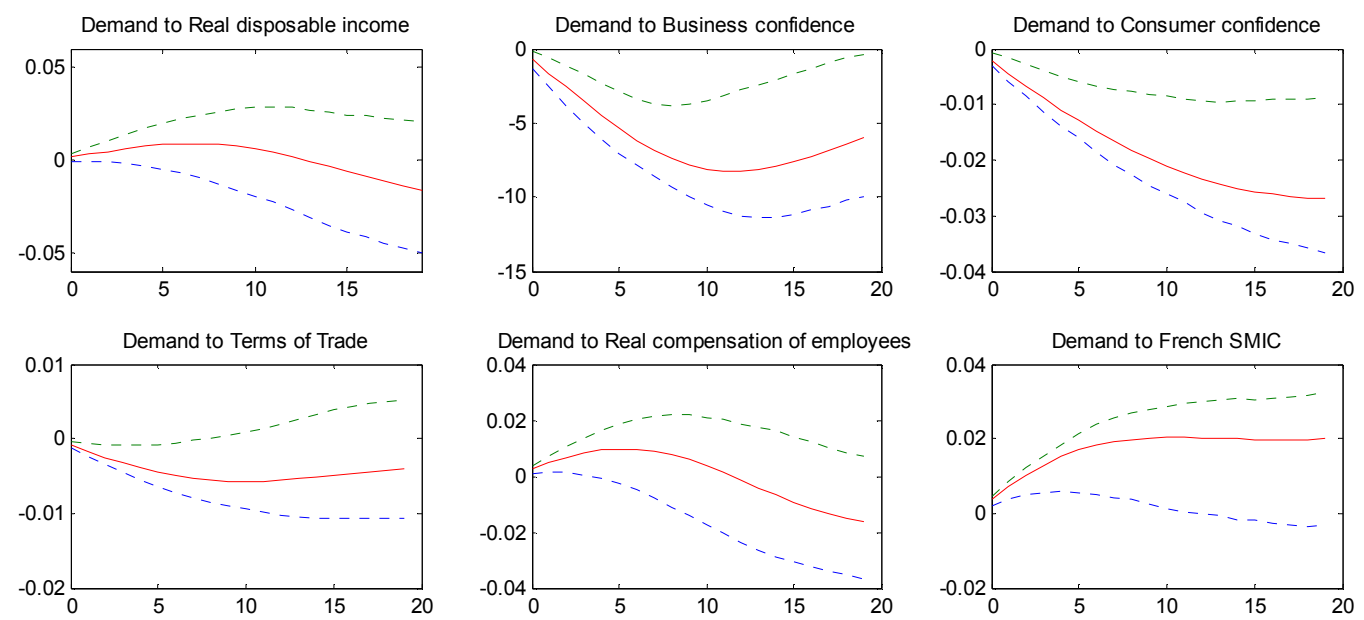

Demand to Real compensation of employees
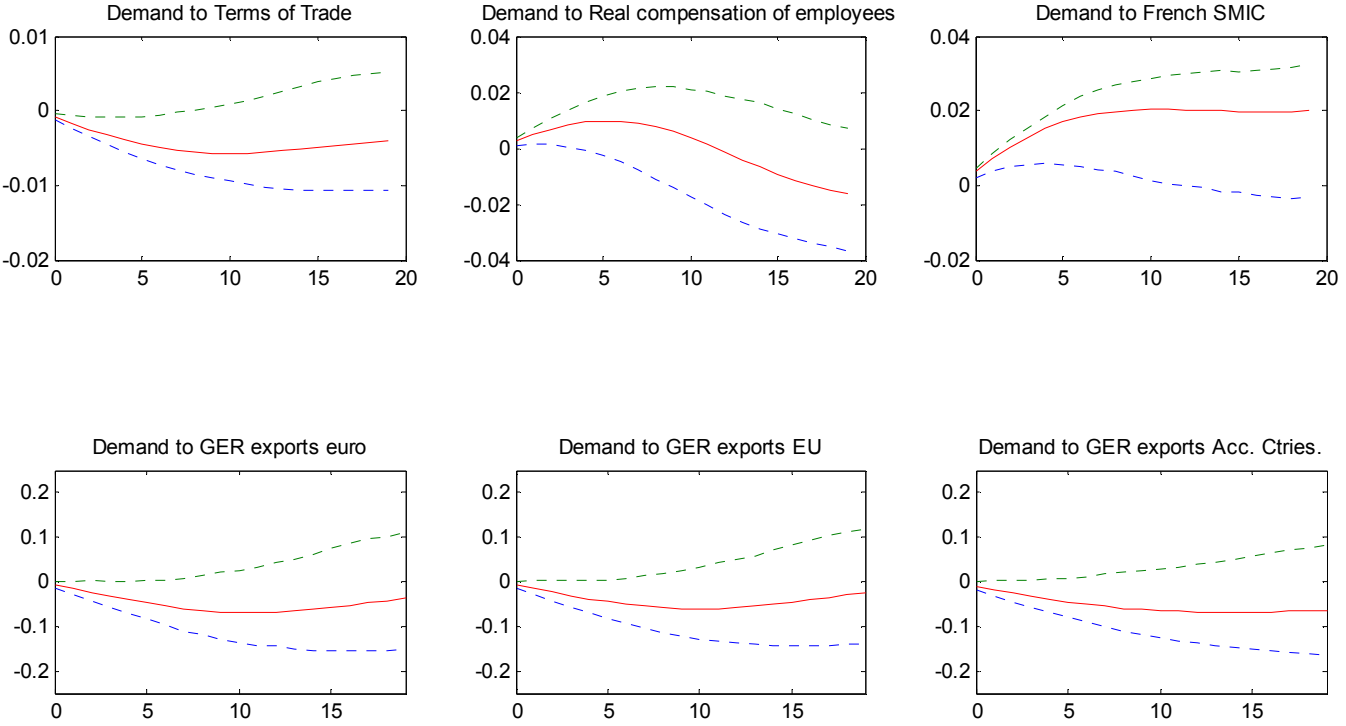

Demand to GER exports Acc. Ctries.
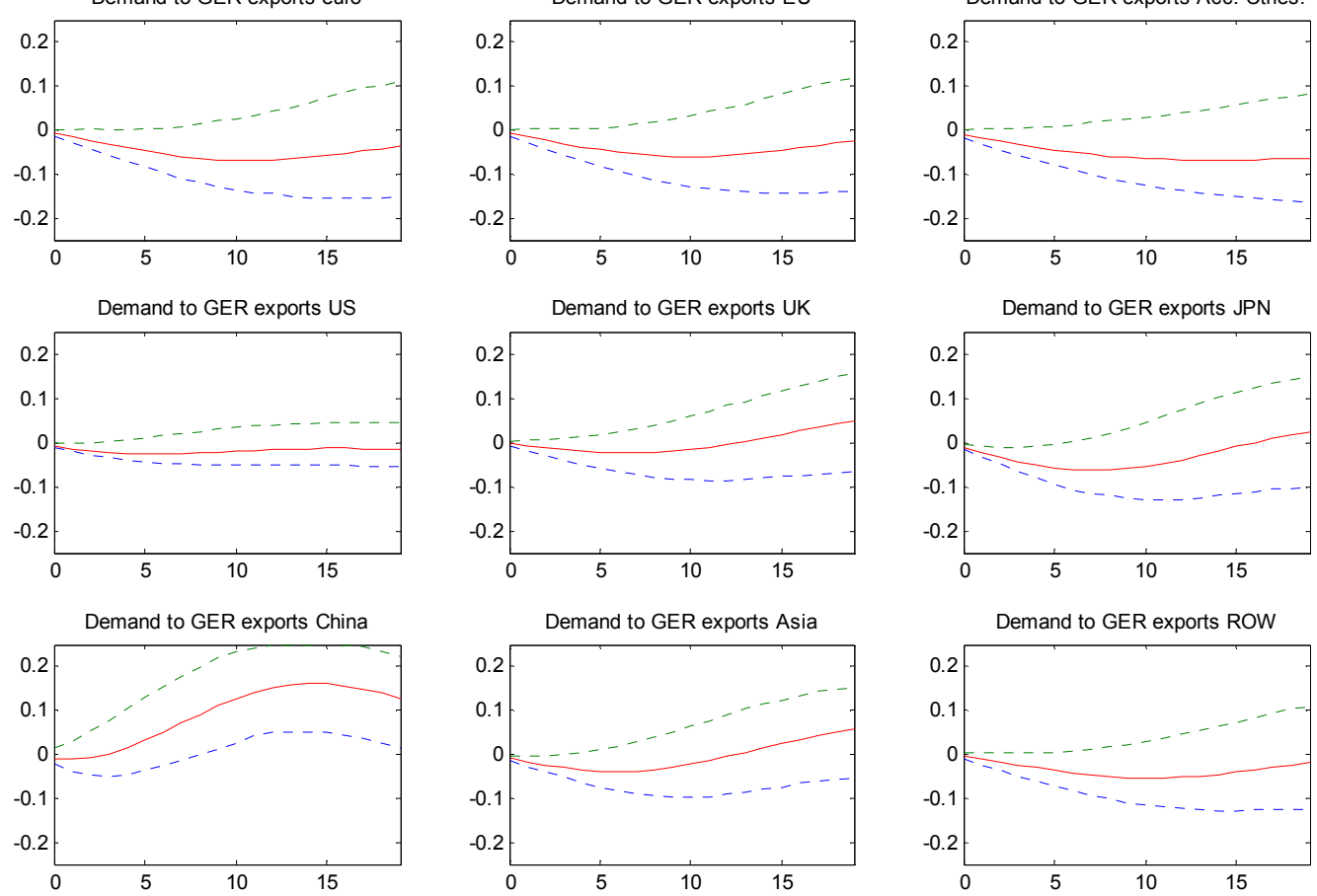
Supply to GER imports miscellaneous manufacterimaty to GER imports commodities and transct. n.e.c. Supply to GER total exports
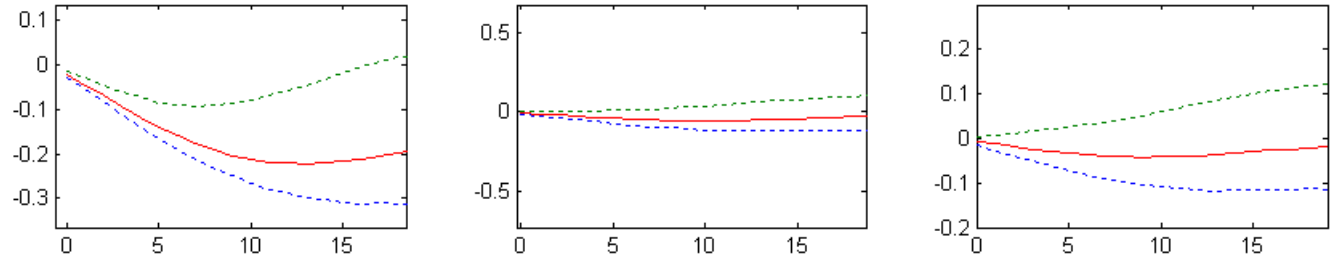

Supply to GER exports food \& live animal

Supply to GER exports beveridges and tobacco Supply to GER exports crude materials excp. fuels
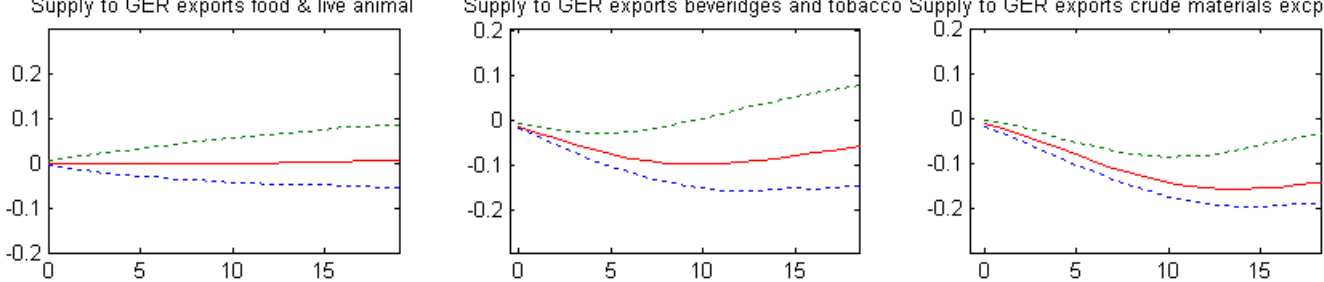

Supply to GER exports mineral fuels and lubricanßupply to GER exports animal \& vegetable oils, f\&epply to GER exports chemicals \& related products
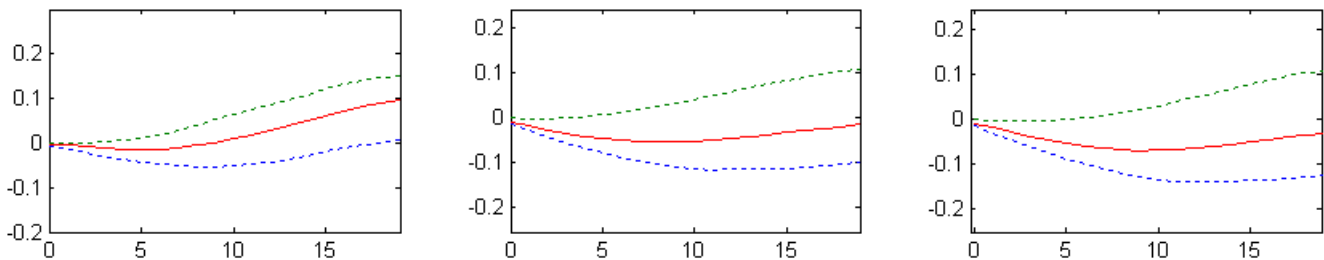

Supply to GER exports manufacturd goodsSupply to GER exports machinery \& transport equipmentipply to GER exports miscellaneous products
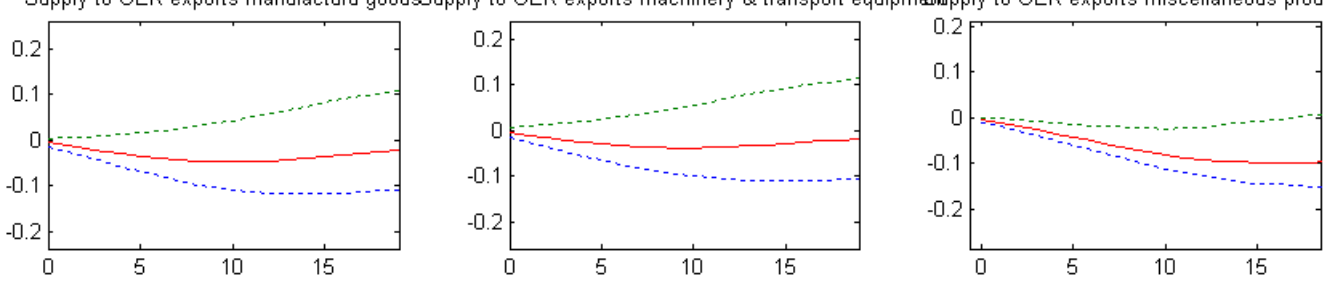

Supply to GER exports commodities and transact. n.e.c.

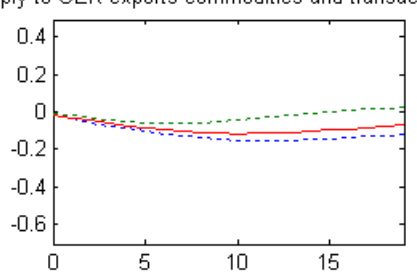




\section{Germany: Shocks to TOT}
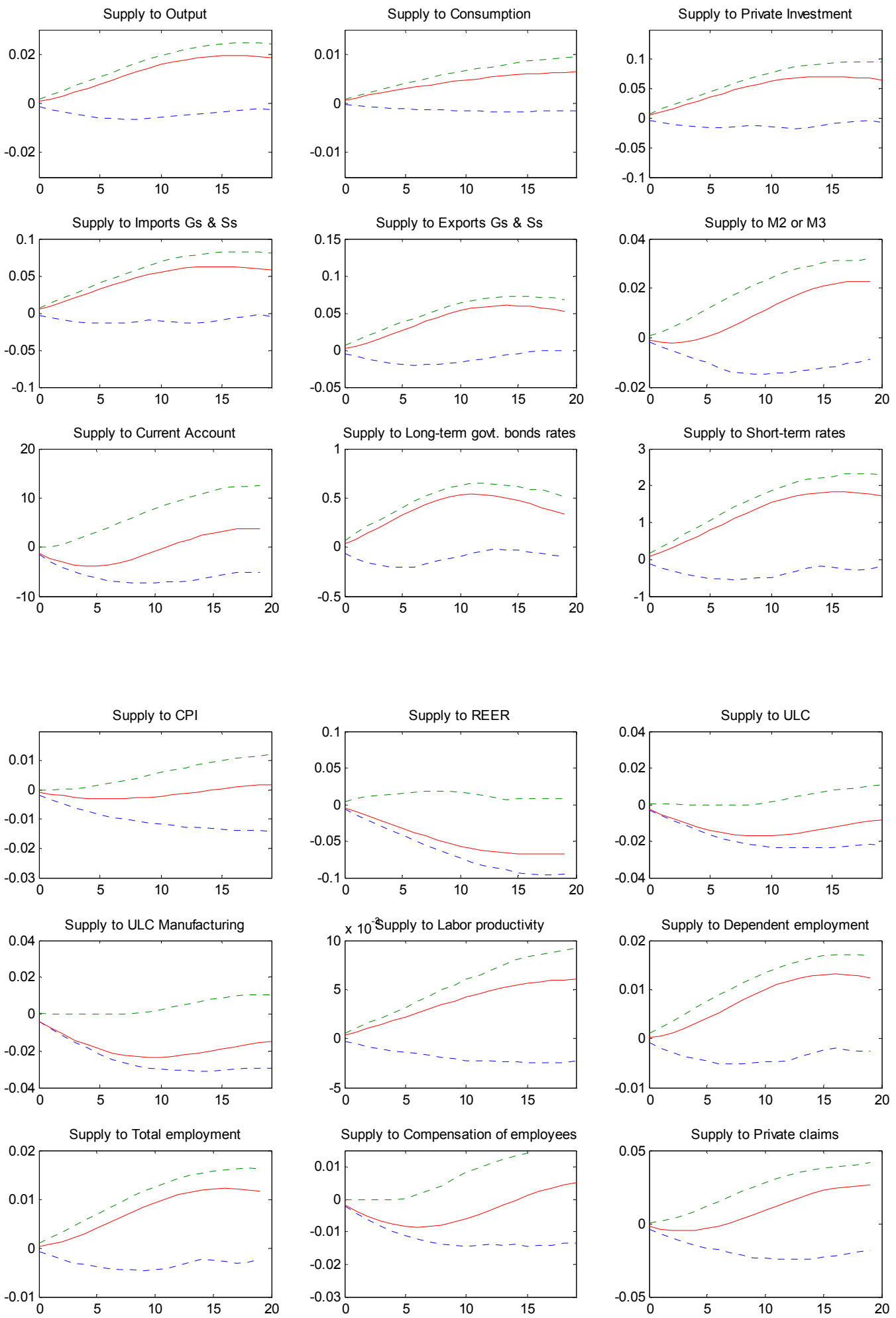

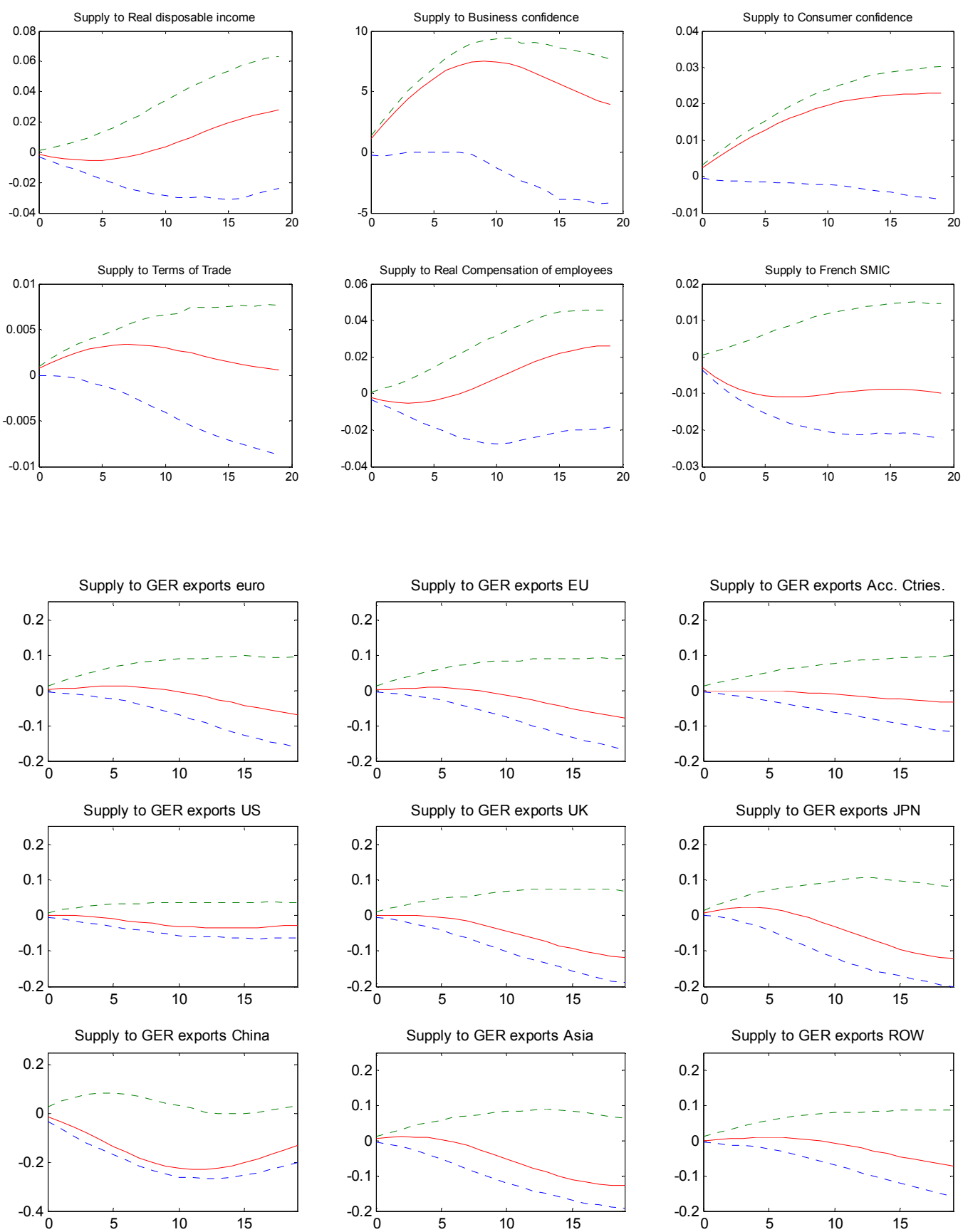

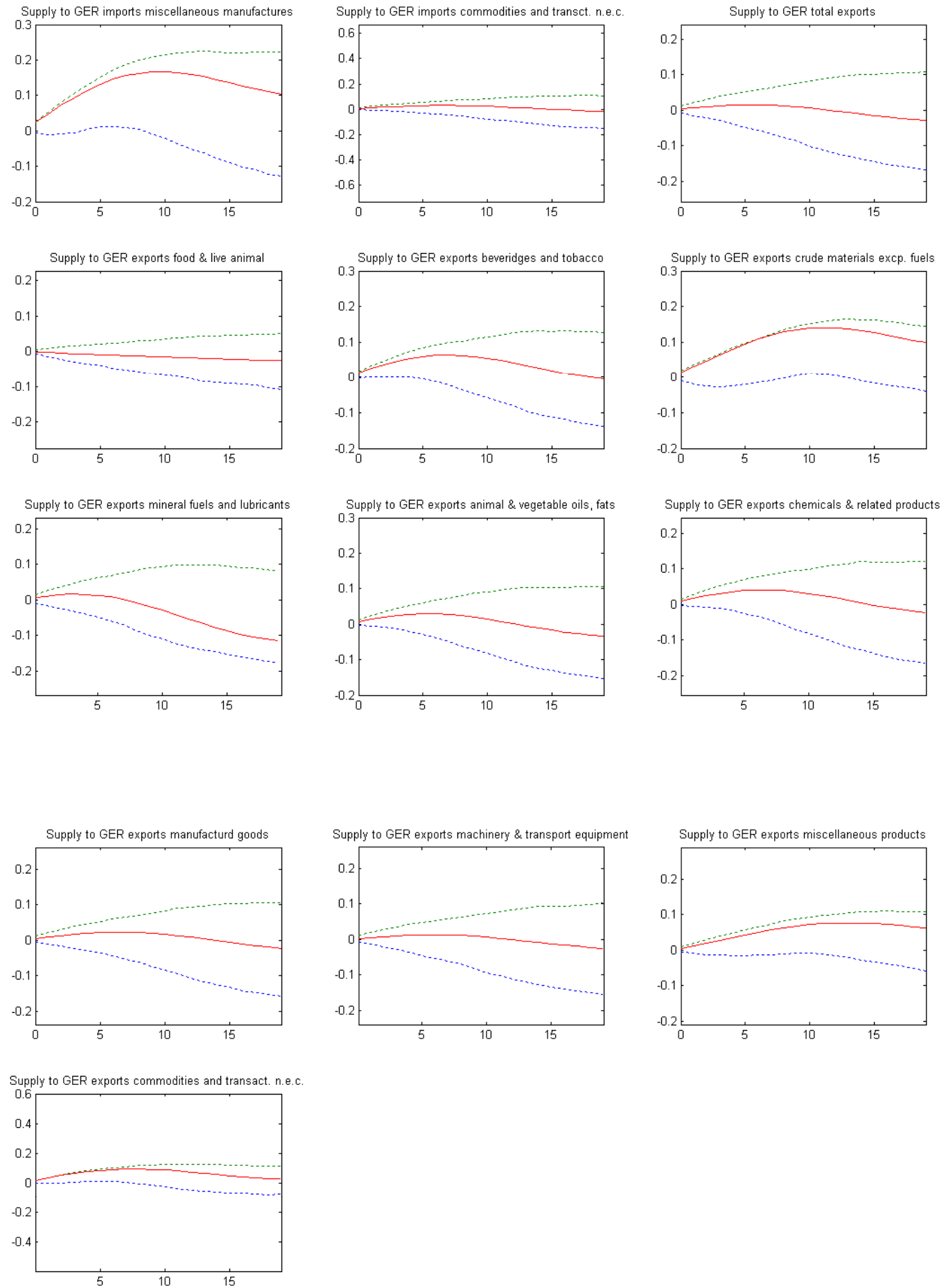

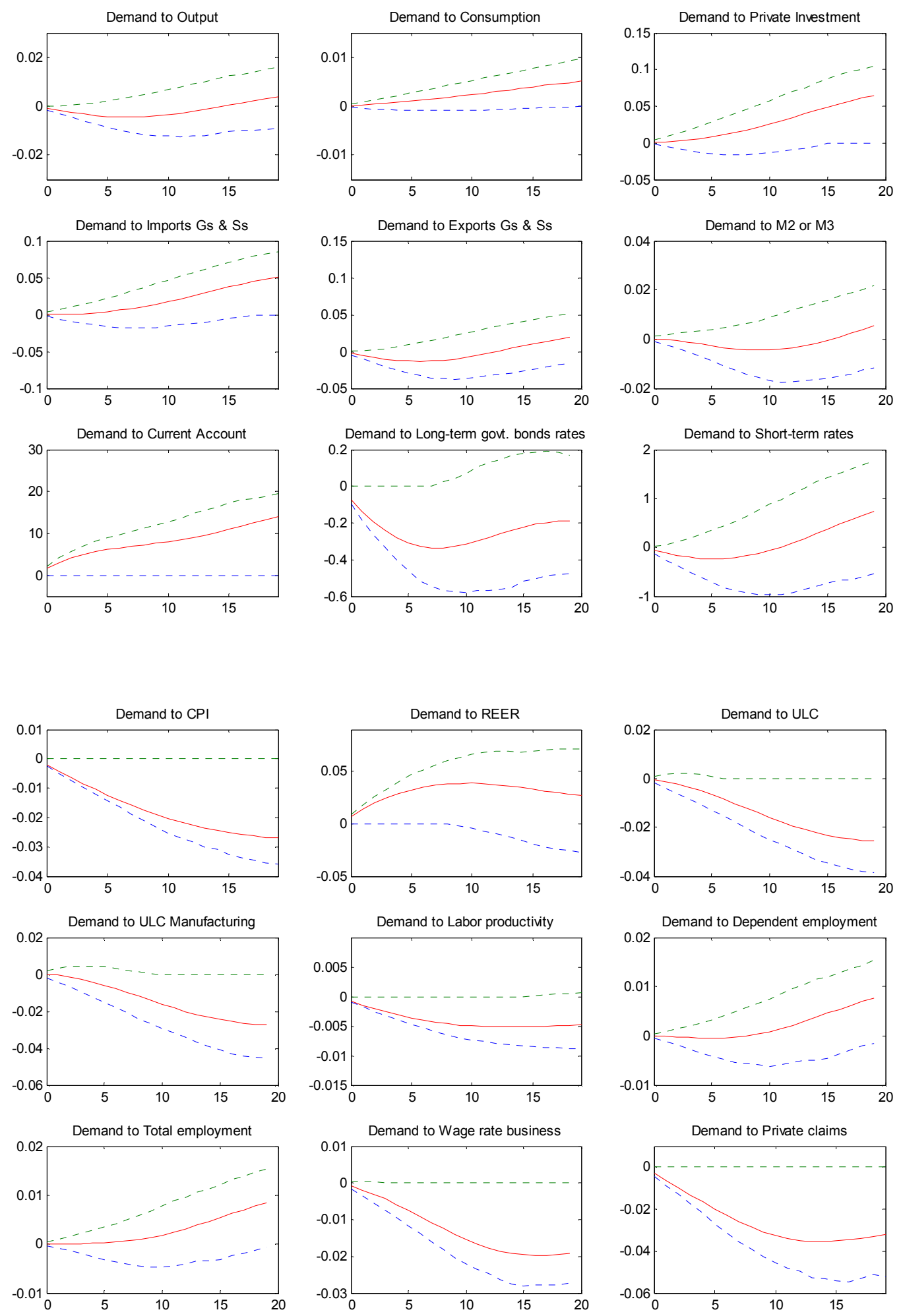

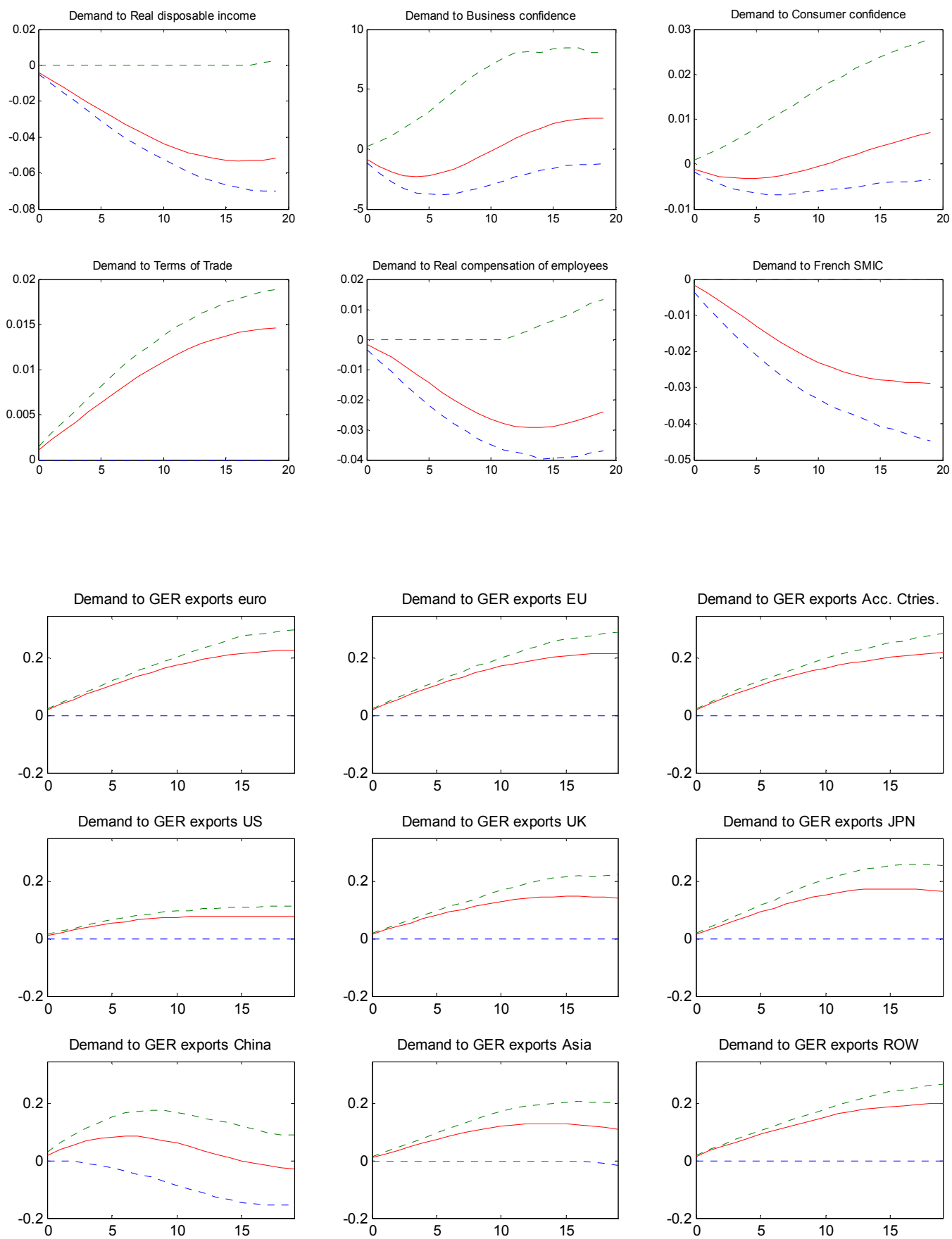

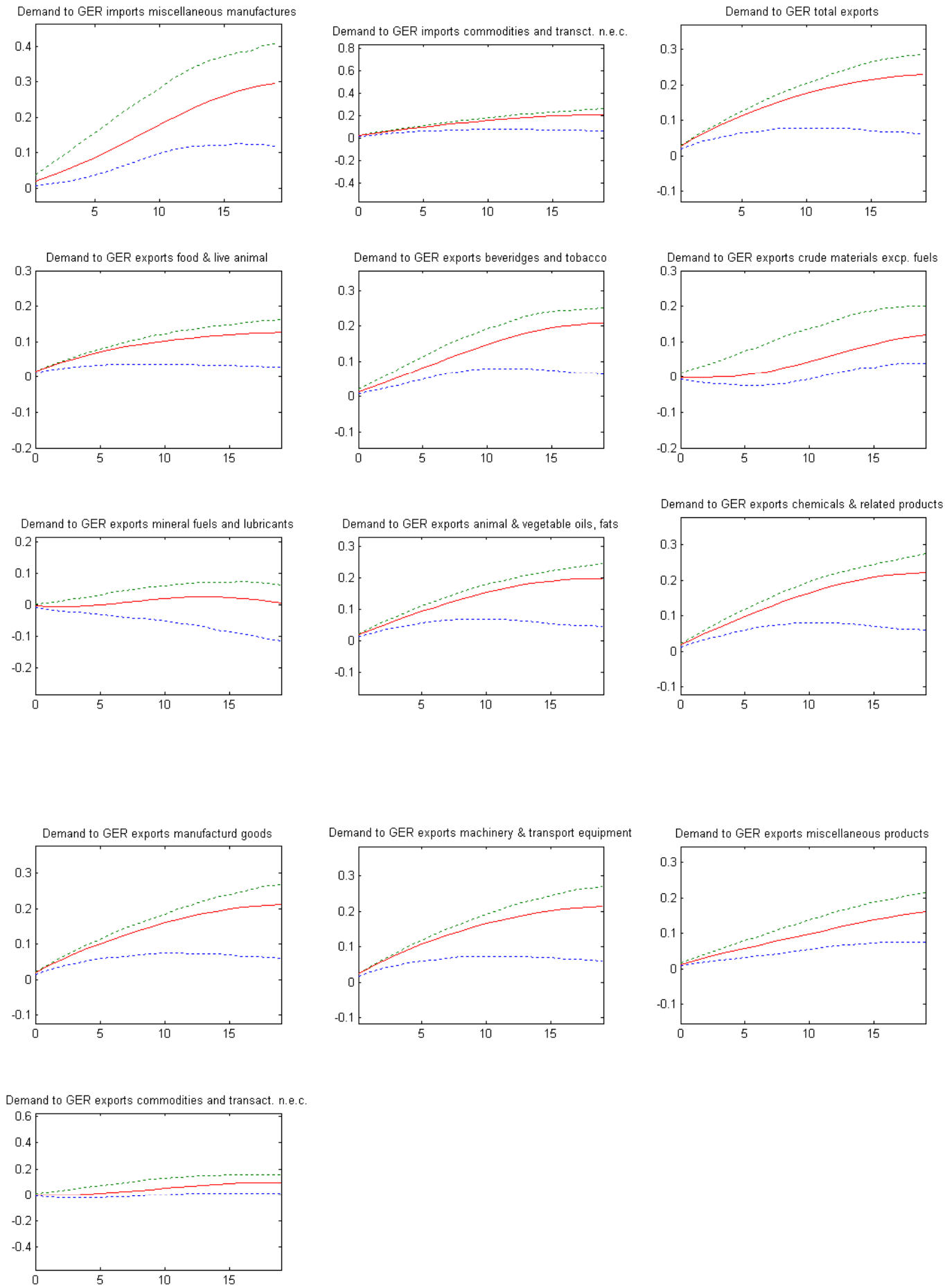


\section{REFERENCES}

Altig, D., L.J. Christiano, M. Eichenbaum, and J. Linde, 2002, “Technology Shocks and Aggregate Fluctuations," manuscript.

Bai, J., and S. Ng, 2002, "Determining the Number of Factors in Approximate Factor Models," Econometrica, 70(1), pp. 191-221.

Bordo, M.D., and T.F. Helbling, 2004, "Have National Business Cycles Become More Synchronized?" in Siebert, Horst (ed.) Macroeconomic Policies in the World Economy, Springer Verlag (Berlin and Heidelberg).

Brooks R., K. Forbes, and A. Mody, 2003, "How strong are Global Linkages?" manuscript, http://www.imf.org/external/np/res/seminars/2003/global/pdf/over.pdf.

Canova, F., 2005, "The Transmission of U.S. Shocks to Latin America," Journal of Applied Econometrics, 20(2), pp. 229-251.

_, and M. Ciccarelli, 2006, "Estimating Multi-Country VAR Models," ECB Working Paper 603.

— - and E. Ortega, 2007, "Similarities and Convergence in G-7 Countries," Journal of Monetary Economics, 53(3), pp. 850-878.

Canova, F., and Dellas, 1993, "Trade Interdependence and the International Business Cycle," Journal of International Economics, 34, pp. 23-47.

Canova, F., and G. de Nicoló, 2003, "On the Sources of Business Cycles in the G-7," Journal of International Economics, 46, pp. 133-66.

Chamberlain, G., 1983, "Funds, Factors, and Diversification in Arbitrage Pricing Models," Econometrica, 51, pp. 1281-304.

— , and M. Rothschild, 1983, "Arbitrage, Factor Structure and Mean-Variance Analysis in Large Markets," Econometrica, 51, pp. 1305-24.

Ciccarelli, M. and A. Rebucci, 2006, "Has the Transmission Mechanism of European Monetary Policy Changed in the Run-Up to EMU?" European Economic Review, 50(3), pp. 737-776.

Corbae, D., and S. Ouliaris, 2006, "Extracting Cycles from Non-Stationary Data," Econometric Theory and Practice: Frontiers of Analysis and Applied Research, Cambridge University Press, D. Corbae, S. Durlauf and B. Hansen, eds. 
Eickmeier, S., 2007, "Business Cycle Transmission from the U.S. to Germany-A Structural Factor Approach," European Economic Review, 51, pp. 521-551. , and J. Breitung, 2006, "How synchronized are new EU member states with the euro area? Evidence from a structural factor model," Journal of Comparative Economics, Vol. 34(3), pp. 538-563.

Forni, M., D. Giannone, M. Lippi, and L. Reichlin, 2005, "Opening the Black Box: Structural Factor Models with Large Cross-Sections," manuscript.

Geweke, J., 1977, "The Dynamic Factor Analysis of Economic Time Series," in Latent Variables in Socio-Economic Models, edited by D.J. Aigner and A.S. Golberger (Amsterdam: North-Holland), p. 19.

Giannone, D., L. Reichlin, and L. Sala, 2002, "Tracking Greenspan: Systematic and Unsystematic Monetary Policy Revised,” CEPR Working Paper 3550.

Hannan, E.J., 1970, “Multiple Time Series” (New York: Wiley).

Harding, D., and A. Pagan, 2002, "Dissecting the Cycle: A Methodological Investigation," Journal of Monetary Economics, 49, pp. 365-381.

Heitz B, F. Hild, and B. Monfort, 2004, "Synchronisation des Cycles au sein du G-7 et Intégration Commerciale et Financière," Note de Conjoncture, INSEE.

Imbs, J., 2004, "Trade, Finance, Specialization and Synchronization," Review of Economics and Statistics, 86(3), pp. 723-34.

International Monetary Fund, 2001, World Economic Outlook October 2001, pp. 65-79 (Washington).

— 2004, GEM: A New International Macroeconomic Model, IMF Occasional Paper No. 239 (Washington).

— 2005, France, Germany, Italy, and Spain: Explaining Differences in External Sector Performance Among Large Euro Area Countries, IMF Country Report No. 05/401 (Washington).

Kabundi, A., and F. Nadal De Simone, 2007, "France in the Global Economy: A Structural Approximate Dynamic Factor Model Analysis," IMF Working Paper 07/129 (Washington: International Monetary Fund).

Khan, T., 2006, "Productivity Growth, Technological Convergence, R\&D, Trade and Labour Markets: Panel Data Evidence from the French Manufacturing Sector," IMF Working Paper 06/230 (Washington: International Monetary Fund). 
Kose, M.A., C. Otrok, and C.H. Whiteman, 2003, "International Business Cycles: World, Region, and Country-Specific Factors," American Economic Review, 93(4), pp. 1216-39.

— 2005, "Understanding the Evolution of World Business Cycles," IMF Working Paper 05/211 (Washington: International Monetary Fund).

Kose, M.A., E.S. Prasad, and M.E. Terrones, 2003, "How Does Globalization Affect the Synchronization of Business Cycles?" American Economic Association Papers and Proceedings, 93(2), pp. 57-62.

Kose, M.A., and K. Yi, 2006, "Can the Standard International Business Model Explain the Relation between Trade and Comovement?” Journal of International Economics, 68, pp. 267-295.

Lumsdaine, R.L., and E.S. Prasad, 2003, "Identifying the Common Component in International Economic Fluctuations: A New Approach,” The Economic Journal, 113(484), pp. 101-27.

Malek Mansour, J., 2003, “Do National Business Cycles Have an International Origin?" Empirical Economics, 28, pp. 223-247.

Monfort, A., J.P. Rennee, R. Rüffer, and G. Vitale, 2004, "Is Economic Activity in the G-7 Synchronized? Common Shocks Versus Spillover Effects," CEPR Discussion Paper 4119.

Nadal-De Simone, F., 2002, “Common and Idiosyncratic Components in Real Output: Further International Evidence,” IMF Working Paper 02/229 (Washington: International Monetary Fund).

Peersman, G., 2005, "What Caused the Early Millennium Slowdown? Evidence Based on Vector Autoregressions," Journal of Applied Econometrics, 20, pp. 185-207.

Sargent, T.J., and C.A. Sims, 1977, "Business Cycle Modeling Without Pretending to Have Too Much A Priori Economic Theory," in New Methods in Business Research, edited by C.A. Sims (Minneapolis: Federal Reserve Bank of Minneapolis).

Sims, C.A. and T. Zha, 1999, "Error Bands for Impulse Responses,” Econometrica, 67(5), pp. 1113-55.

Stock, J.H., and M.W. Watson, 1991, “A Probability Model of the Coincident Economic Indicators," Leading Economic Indicators, ed. by K. Lahiri and G.H. Moore (Cambridge, England: Cambridge University Press).

—_, 1998, “Diffusion Indexes,” NBER Working Paper 6702. 
— 2002, "Macroeconomic Forecasting Using Diffusion Indexes," Journal of Business \& Economic Statistics, 20(2), pp. 147-162.

— 2003, "Has the Business Cycle Changed? Evidence and Explanations," in Monetary Policy and Uncertainty, Federal Reserve Bank of Kansas City, pp. 9-56.

Uhlig, H., 2003, “What Moves Real GNP?” manuscript.

Yang, X., 2003, “The Role of World Common Shocks in International Economic Fluctuations," manuscript. 